\title{
Hydrogen-Halogen Exchange of Phosphines for the Rapid Formation of Cyclopolyphosphines
}

Adam N. Barrett ${ }^{a}$, Callum R. Woof ${ }^{a}$, Christopher A. Goult ${ }^{b}$, Danila Gasperini ${ }^{a}$, Mary F. Mahon ${ }^{a \star}$ and Ruth L. Webster ${ }^{*}$

\begin{abstract}
${ }^{a}$ Department of Chemistry, University of Bath, Claverton Down, Bath, BA2 7AY, United Kingdom
${ }^{b}$ Department of Chemistry, University of York, Heslington, York, YO10 5DD, United Kingdom
\end{abstract}

rw498@bath.ac.uk

\section{Contents}

1. General Considerations

2. Synthesized Dichlorophosphines and Precursors

4. General Procedure for the Synthesis of Secondary Phosphines via Reduction of Secondary Phosphine Oxides.

5. Synthesised Secondary Phosphines

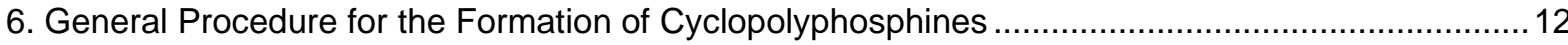

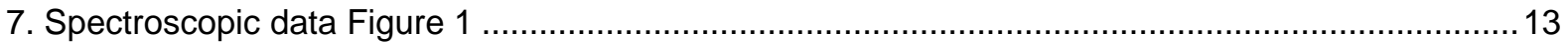

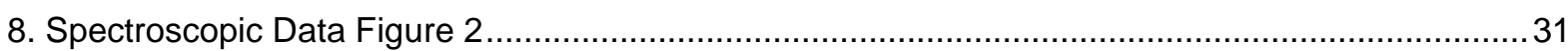

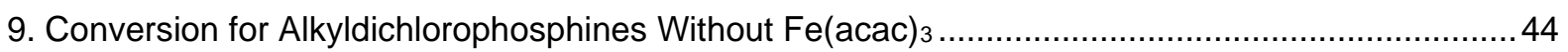

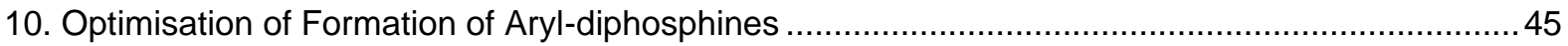

11. General Procedure for the Formation of Aryl-diphosphines via Fe(acac) $)_{3}$ Mediated

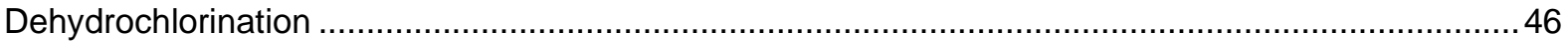

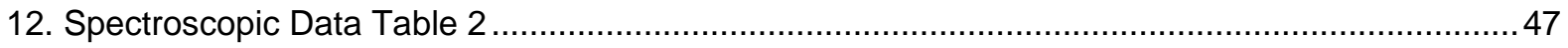

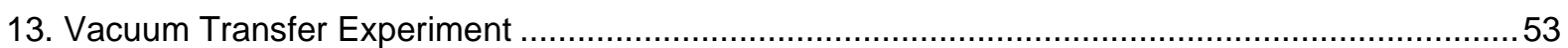

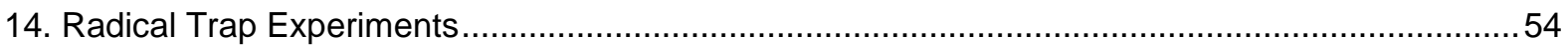

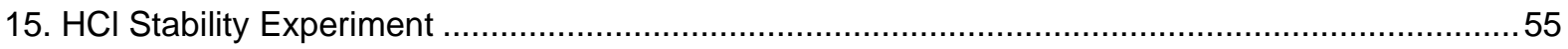

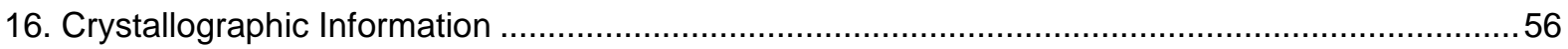

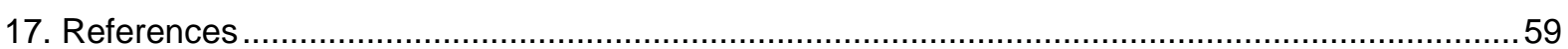




\section{General Considerations}

Reagents were obtained from commercial sources (Sigma Aldrich, Fischer, ACROS) and dried/distilled before use. Diisopropylphosphine was purchased as a $10 \mathrm{wt}$ \% solution in hexanes (ACROS) and was concentrated under vacuum and distilled before use. Pentane, diethyl ether, THF, toluene and acetonitrile were dried over sodium/benzophenone and distilled before use. Dichloromethane was dried over calcium hydride and distilled before use. NMR data was collected at 300,400 or $500 \mathrm{MHz}$ on Bruker or Agilent instruments in $\mathrm{C}_{6} \mathrm{D}_{6} / \mathrm{CD}_{2} \mathrm{Cl}_{2} / \mathrm{CDCl}_{3} / \mathrm{CD}_{3} \mathrm{CN}$ at $298 \mathrm{~K}$ and referenced to residual protic solvent. Solid-state ${ }^{13} \mathrm{C}\left\{{ }^{1} \mathrm{H}\right\}$ and ${ }^{31} \mathrm{P}\left\{{ }^{1} \mathrm{H}\right\}$ NMR spectra were acquired on a Bruker AVHDIII $400 \mathrm{MHz}$ solids spectrometer (operating frequencies: $400.13 \mathrm{MHz}$ for ${ }^{1} \mathrm{H}, 161.98 \mathrm{MHz}$ for ${ }^{31} \mathrm{P}, 100.61 \mathrm{MHz}$ for ${ }^{13} \mathrm{C}$ ) using a $4 \mathrm{~mm}$ probe. The magnetic field was externally referenced by recording the ${ }^{13} \mathrm{C}$ spectra of a sample of adamantane and setting the downfield resonance to $\delta=38.4 \mathrm{ppm}$. The samples were finely ground and packed into a $4 \mathrm{~mm} \mathrm{ZrO}_{2}$ rotor fitted with a Kel-F drive cap. Cross polarization magic angle spinning experiments were used to measure the ${ }^{13} \mathrm{C}\left\{{ }^{1} \mathrm{H}\right\}$ and ${ }^{31} \mathrm{P}\left\{{ }^{1} \mathrm{H}\right\}$ spectra. Solid-state NMR spectra were processed using Bruker TopSpin 3.6.1 pl7. All manipulations were carried out under an inert atmosphere using standard Schlenk and glovebox techniques, unless otherwise stated. Crystal structures were obtained from either a Rigaku Oxford Diffraction Xcalibur (MoKa $(\lambda=0.71073)$ ) or Supernova (CuKa $(\lambda=1.54184)$ ) diffractometer. HRMS analyses were performed using an Agilent QTOF 6545 with Jetstream ESI spray source coupled to an Agilent 1260 Infinity II Quat pump HPLC with 1260 autosampler, column oven compartment and variable wavelength detector (VWD). Melting point analyses were conducted on a Stuart SMP10 melting point apparatus. Infrared spectra were recorded at ambient temperature on a Perkin Elmer Spectrum 100 FT-IR spectrometer using a diamond ATR unit. Intensities are reported relative to the most intense signal as vw (very weak), w (weak), s (strong) or vs (very strong). 


\title{
2. Synthesized Dichlorophosphines and Precursors
}

\author{
$\mathrm{Me}_{3} \mathrm{SiCH}_{2} \mathrm{PCl}_{2}$ :
}

$$
\mathrm{Me}_{3} \mathrm{Si} \smile \mathrm{PCl}_{2}
$$

Following literature procedure, ${ }^{1}$ magnesium turnings $(0.5 \mathrm{~g}, 20.5 \mathrm{mmol})$ were suspended in diethyl ether $(10 \mathrm{~mL})$ in a Schlenk tube equipped with a water-cooled reflux condenser. An ethereal $(10 \mathrm{~mL})$ solution of $\mathrm{Me}_{3} \mathrm{SiCH}_{2} \mathrm{Cl}(1.6 \mathrm{~mL}, 11.4 \mathrm{mmol})$ was added slowly until a self-initiated Grignard reaction occurred, after which the solution was allowed to cool to room temperature over 2 hours. The solution was then filtered into a solution of $\mathrm{PCl}_{3}(1.0 \mathrm{~mL}, 11.4 \mathrm{mmol})$ in diethyl ether $(10 \mathrm{~mL})$ held at $-20^{\circ} \mathrm{C}$, upon which a white precipitate formed. The mixture was then stirred overnight before extraction with diethyl either $(3 \times 10 \mathrm{~mL})$. The solvent was removed in vacuo before the crude product was distilled at reduced pressure $\left(50{ }^{\circ} \mathrm{C}, 1 \mathrm{mbar}\right)$ to yield $\mathrm{Me}_{3} \mathrm{SiCH}_{2} \mathrm{PCl}_{2}$ as a colourless liquid $(1.2 \mathrm{~g}, 56 \%)$.

${ }^{1} \mathrm{H}$ NMR $\left(300 \mathrm{MHz}, 298 \mathrm{~K}, \mathrm{C}_{6} \mathrm{D}_{6}\right): \delta 1.54\left(\mathrm{~d}, 2 \mathrm{H},{ }^{2} \mathrm{JH}_{\mathrm{H}-\mathrm{P}}=15.9 \mathrm{~Hz}, \mathrm{CH}_{2} \mathrm{PCl}_{2}\right),-0.09$ (s, 9H, SiMe $) .{ }^{31} \mathbf{P}$ NMR $\left(162 \mathrm{MHz}, 298 \mathrm{~K}, \mathrm{C}_{6} \mathrm{D}_{6}\right): \delta 205.4\left(\mathrm{t},{ }^{2} \mathrm{JP}-\mathrm{H}=15.1 \mathrm{~Hz}\right)$. The values are in accordance to the literature. ${ }^{1}$

\section{(p-Tol) $\mathrm{Me}_{2} \mathrm{SiCH}_{2} \mathrm{Cl}$ :}<smiles>Cc1ccc([Si](C)(C)CCl)cc1</smiles>

Following literature procedure, ${ }^{2}$ magnesium turnings $(0.63 \mathrm{~g}, 26.0 \mathrm{mmol})$ were suspended in diethyl ether $(10 \mathrm{~mL})$ in a Schlenk tube equipped with a water-cooled reflux condenser. An ethereal $(10 \mathrm{~mL})$ solution of 4-bromotoluene $(2.67 \mathrm{~mL}, 21.7 \mathrm{mmol})$ was added slowly until a self-initiated Grignard reaction occurred, after which the solution was allowed to cool to room temperature over 2 hours. This solution was then filtered into an ethereal $(10 \mathrm{~mL})$ solution of $\mathrm{CIMe}_{2} \mathrm{SiCH}_{2} \mathrm{Cl}(3.4 \mathrm{~mL}, 25.8 \mathrm{mmol})$ held at $-20^{\circ} \mathrm{C}$. After 45 mins, the mixture was brought to reflux for $18 \mathrm{~h}$, before being allowed to cool to room temperature. The solvent was removed in vacuo before the residue was distilled at reduced pressure $\left(55^{\circ} \mathrm{C}, 1 \mathrm{mbar}\right.$ ) to give ( $p$-Tol) $\mathrm{Me}_{2} \mathrm{SiCH}_{2} \mathrm{Cl}$ as a colourless liquid $(2.9 \mathrm{~mL}, 59 \%)$.

${ }^{1} \mathrm{H}$ NMR $\left(300 \mathrm{MHz}, 298 \mathrm{~K}, \mathrm{C}_{6} \mathrm{D}_{6}\right): \delta 7.31$ (d, 2H, $\left.{ }^{3} \mathrm{JH}_{\mathrm{H}-\mathrm{H}}=7.2 \mathrm{~Hz}, \mathrm{Ar}-\mathrm{H}\right), 7.03\left(\mathrm{~d}, 2 \mathrm{H},{ }^{3} \mathrm{~J}_{\mathrm{H}-\mathrm{H}}=7.2 \mathrm{~Hz}, \mathrm{Ar}-\right.$ H), $2.67\left(\mathrm{~s}, 2 \mathrm{H}, \mathrm{CH}_{2} \mathrm{Cl}\right), 2.12(\mathrm{~s}, 3 \mathrm{H}, \mathrm{Ar}-\mathrm{Me}), 0.26\left(\mathrm{~s}, 6 \mathrm{H}, \mathrm{SiMe}_{2} \mathrm{pTol}\right)$. The values are in accordance to the literature. ${ }^{2}$

\section{(p-Tol) $\mathrm{Me}_{2} \mathrm{SiCH}_{2} \mathrm{PCl}_{2}$ :}<smiles>Cc1ccc([Si](C)(C)CP)cc1</smiles>

In an adaptation to literature procedure, ${ }^{2}$ a solution of ( $\left.p-\mathrm{Tol}\right) \mathrm{Me}_{2} \mathrm{SiCH}_{2} \mathrm{Cl}(1.80 \mathrm{~mL}, 10.2 \mathrm{mmol})$ in diethyl ether $(5 \mathrm{~mL})$ was added, dropwise, to an ethereal solution $(10 \mathrm{~mL})$ of magnesium turnings $(0.858 \mathrm{~g}, 35.3$ $\mathrm{mmol}$ ) at a rate to maintain reflux. The reaction was then stirred for $2 \mathrm{~h}$ at room temperature. The mixture was then filtered into a solution of $\mathrm{PCl}_{3}(1.34 \mathrm{~mL}, 15.4 \mathrm{mmol})$ in diethyl ether $(10 \mathrm{~mL})$ held at $-78{ }^{\circ} \mathrm{C}$. This mixture was stirred for 30 mins, before being allowed to warm to room temperature over the course of $18 \mathrm{~h}$. The solution was then filtered before the residues were extracted with diethyl ether $(3 \times 10 \mathrm{~mL})$. 
The solvent was then removed in vacuo and the crude product distilled under vacuum $\left(95^{\circ} \mathrm{C}, 1 \mathrm{mbar}\right)$ to give ( $p$-Tol) $\mathrm{Me}_{2} \mathrm{SiCH}_{2} \mathrm{PCl}_{2}$ as a colourless liquid (0.431 g, 16\%).

${ }^{1} \mathrm{H}$ NMR $\left(300 \mathrm{MHz}, 298 \mathrm{~K}, \mathrm{C}_{6} \mathrm{D}_{6}\right): \delta 7.31\left(\mathrm{~d}, 2 \mathrm{H},{ }^{3} \mathrm{~J}-\mathrm{H}=7.7 \mathrm{~Hz}, \mathrm{Ar}-\mathrm{H}\right), 7.03\left(\mathrm{~d}, 2 \mathrm{H},{ }^{3} \mathrm{~J}_{\mathrm{H}-\mathrm{H}}=7.7 \mathrm{~Hz}, \mathrm{Ar}-\mathrm{H}\right)$, $2.12(\mathrm{~s}, 3 \mathrm{H}, \mathrm{Ar}-\mathrm{Me}), 1.84$ (d, 2H, ${ }^{2} \mathrm{JH}_{\mathrm{H}} \mathrm{P}=15.7 \mathrm{~Hz}, \mathrm{CH}_{2} \mathrm{PCl}$ ), 0.22 (s, 6H, SiMe $\left.{ }_{2} \mathrm{pTol}\right) .{ }^{31} \mathrm{P}$ NMR (162 $\left.\mathrm{MHz}, 298 \mathrm{~K}, \mathrm{C}_{6} \mathrm{D}_{6}\right): \delta 203.8\left(\mathrm{t},{ }^{2} \mathrm{JP}-\mathrm{H}=15.0 \mathrm{~Hz}\right)$. The values are in accordance to the literature. ${ }^{2}$

\section{$\mathrm{PhMe}_{2} \mathrm{SiCH}_{2} \mathrm{Cl}$ :}<smiles>C[Si](C)(CCl)c1ccccc1</smiles>

Following literature procedure, ${ }^{3}$ a solution of phenylmagnesiumbromide $(1.58 \mathrm{M}, 17.7 \mathrm{~mL}, 28.0 \mathrm{mmol})$, previously prepared from the reaction of bromobenzene and magnesium, was added to an ethereal (10 $\mathrm{mL}$ ) solution of $\mathrm{CIMe}_{2} \mathrm{SiCH}_{2} \mathrm{Cl}(3.4 \mathrm{~mL}, 25.8 \mathrm{mmol})$ at $-20^{\circ} \mathrm{C}$. After $45 \mathrm{mins}$, the mixture was brought to reflux for $18 \mathrm{~h}$, before being allowed to cool. The solvent was removed in vacuo before the residue was distilled at reduced pressure $\left(55^{\circ} \mathrm{C}, 1 \mathrm{mbar}\right)$ to give $\mathrm{PhMe}_{2} \mathrm{SiCH}_{2} \mathrm{Cl}$ as a colourless liquid $(0.91 \mathrm{~g}, 19 \%)$.

${ }^{1} \mathrm{H}$ NMR $\left(300 \mathrm{MHz}, 298 \mathrm{~K}, \mathrm{C}_{6} \mathrm{D}_{6}\right): \delta$ 7.37-7.31 (m, 2H, Ar-H), 7.19-7.13 (m, 3H, Ar-H), 2.63 (s, 2H, $\left.\mathrm{CH}_{2} \mathrm{Cl}\right), 0.22(\mathrm{~s}, 6 \mathrm{H}, \mathrm{SiMe} 2 \mathrm{pTol})$. The values are in accordance to the literature. ${ }^{3}$

\section{$\mathrm{PhMe}_{2} \mathrm{SiCH}_{2} \mathrm{PCl}_{2}$ :}<smiles>C[Si](C)(CP)c1ccccc1</smiles>

Following literature procedure, ${ }^{1}$ a solution of $\mathrm{PhMe}_{2} \mathrm{SiCH}_{2} \mathrm{Cl}(0.93 \mathrm{~g}, 5.0 \mathrm{mmol})$ in diethyl ether $(5 \mathrm{~mL})$ was added, dropwise, to an ethereal solution $(5 \mathrm{~mL})$ of magnesium turnings $(0.25 \mathrm{~g}, 9.0 \mathrm{mmol})$ at a rate to maintain reflux. The reaction was then stirred for $2 \mathrm{~h}$ at room temperature. The mixture was then filtered into a solution of $\mathrm{PCl}_{3}(0.44 \mathrm{~mL}, 5.0 \mathrm{mmol})$ in diethyl ether $(5 \mathrm{~mL})$ held at $-20{ }^{\circ} \mathrm{C}$. This mixture was stirred for 30 mins, before being allowed to warm to room temperature over the course of $18 \mathrm{~h}$. The solution was then filtered before the remaining residue was extracted with diethyl ether $(3 \times 10 \mathrm{~mL})$. The solvent was then removed in vacuo and the crude product distilled under vacuum $\left(95^{\circ} \mathrm{C}, 1 \mathrm{mbar}\right)$ to give $\mathrm{PhMe}_{2} \mathrm{SiCH}_{2} \mathrm{PCl}_{2}$ as a colourless liquid $(0.487 \mathrm{~g}, 39 \%)$.

${ }^{1} \mathrm{H}$ NMR $\left(300 \mathrm{MHz}, 298 \mathrm{~K}, \mathrm{C}_{6} \mathrm{D}_{6}\right): \delta$ 7.26-7.21 (m, 2H, Ar-H), 7.17-7.11 (m, 3H, Ar-H), $1.70\left(\mathrm{~d}, 2 \mathrm{H},{ }^{2} \mathrm{JH}-\right.$ $\left.\mathrm{P}=15.5 \mathrm{~Hz}, \mathrm{CH}_{2} \mathrm{PCl}_{2}\right), 0.18\left(\mathrm{~s}, 6 \mathrm{H}, \mathrm{SiMe}{ }_{2} \mathrm{pTol}\right) .{ }^{31} \mathrm{P}$ NMR $\left(162 \mathrm{MHz}, 298 \mathrm{~K}, \mathrm{C}_{6} \mathrm{D}_{6}\right): \delta 203.7\left(\mathrm{t},{ }^{2} \mathrm{JP}-\mathrm{H}=\right.$ $15.5 \mathrm{~Hz})$. The values are in accordance to the literature. ${ }^{1}$

\section{$\mathrm{Ph}_{3} \mathrm{SiCH}_{2} \mathrm{Cl}$ :}

$$
\mathrm{Ph}_{3} \mathrm{Si} \sim \mathrm{Cl}
$$

Following literature procedure ${ }^{4}$ activated magnesium turnings $(2.32 \mathrm{~g}, 95.4 \mathrm{mmol})$ were suspended in THF $(10 \mathrm{~mL})$ in a Schenk tube equipped with a water-cooled reflux condenser. A THF $(40 \mathrm{~mL})$ solution of bromobenzene $(10.0 \mathrm{~g}, 63.6 \mathrm{mmol})$ was added slowly to initiate the Grignard reaction, after which the remaining solution was added at a rate to maintain reflux. After full addition, the reaction was stirred at room temperature for two hours. The reaction was filtered then filtered via canula into a $0{ }^{\circ} \mathrm{C}$ THF $(25 \mathrm{~mL})$ solution of $\mathrm{Cl}_{3} \mathrm{SiCH}_{2} \mathrm{Cl}(2.81 \mathrm{~g}, 15.3 \mathrm{mmol})$. The reaction mixture was then heated at reflux for 24 hours before cooling to room temperature and addition of $50 \mathrm{~mL}$ saturated $\mathrm{NH}_{4} \mathrm{Cl}$ and $50 \mathrm{~mL}$ diethyl ether. The organic layer was separated and dried over magnesium sulphate and the solvent removed in vacuo. Subsequent recrystallisation from hot ethanol yielded $\mathrm{Ph}_{3} \mathrm{SiCH}_{2} \mathrm{Cl}$ as colourless crystals $(2.05$ g, 44\%). 
${ }^{1} \mathrm{H}$ NMR $\left(300 \mathrm{MHz}, 298 \mathrm{~K}, \mathrm{CDCl}_{3}\right): \delta$ 7.57-7.62 (m, 6H, Ar-H), 7.36-7.50 (m, 9H, Ar-H), $3.54(\mathrm{~s}, 2 \mathrm{H}$, $\mathrm{CH}_{2} \mathrm{Cl}$ ). The values are in accordance to the literature. ${ }^{4}$

\section{$\mathrm{Ph}_{3} \mathrm{SiCH}_{2} \mathrm{PCl}_{2}$ :}

$$
\mathrm{Ph}_{3} \mathrm{Si} \sim \mathrm{PCl}_{2}
$$

Adapted from literature procedure, ${ }^{5}$ activated magnesium turnings ( $1.36 \mathrm{~g}, 55.9 \mathrm{mmol}$ ) were suspended in THF $(5 \mathrm{~mL})$ in a Schlenk tube equipped with a water-cooler reflux condenser. A THF $(10 \mathrm{~mL})$ solution of $\mathrm{Ph}_{3} \mathrm{SiCH}_{2} \mathrm{Cl}(1.8 \mathrm{~g}, 5.8 \mathrm{mmol})$ was added slowly before initiation of the Grignard reaction, which was then held at reflux for three hours. The solution was then cooled to room temperature before being filtered via cannula into a THF $(10 \mathrm{~mL})$ solution of $\mathrm{PCl}_{3}(1.5 \mathrm{~mL}, 17 \mathrm{mmol})$ held at $-78^{\circ} \mathrm{C}$. The solution was then warmed to room temperature and stirred for 18 hours. Volatiles were then removed in vacuo and the residue extracted with toluene and filtered through celite. Concentration in vacuo gave $\mathrm{Ph}_{3} \mathrm{SiCH}_{2} \mathrm{PCl}_{2}$ as a white solid $(1.33 \mathrm{~g}, 61 \%)$.

${ }^{1} \mathrm{H}$ NMR $\left(500 \mathrm{MHz}, 298 \mathrm{~K}, \mathrm{C}_{6} \mathrm{D}_{6}\right): \delta 7.46(\mathrm{~m}, 6 \mathrm{H}, \mathrm{Ar}-H), 7.08-7.19(\mathrm{~m}, 9 \mathrm{H}, \mathrm{Ar}-\mathrm{H}), 2.59\left(\mathrm{~d}, 2 \mathrm{H},{ }^{2} \mathrm{~J}_{\mathrm{H}-\mathrm{P}}=\right.$ $\left.14.3 \mathrm{~Hz}, \mathrm{CH}_{2} \mathrm{PCl}_{2}\right) .{ }^{31} \mathrm{P}$ NMR $\left(162 \mathrm{MHz}, 298 \mathrm{~K}, \mathrm{C}_{6} \mathrm{D}_{6}\right): \delta 199.4\left(\mathrm{t},{ }^{2} \mathrm{JP}-\mathrm{H}=14.7 \mathrm{~Hz}\right)$. The values are in accordance to the literature. ${ }^{5}$

\section{$\mathrm{C}_{6} \mathrm{H}_{5} \mathrm{CH}_{2} \mathrm{PCl}_{2}$ :}<smiles>O=CCc1ccccc1</smiles>

Following literature procedure, activated magnesium turnings $(0.30 \mathrm{~g}, 12.34 \mathrm{mmol})$ were suspended in diethyl ether $(10 \mathrm{~mL})$. Benzyl bromide $(1.2 \mathrm{~mL}, 10 \mathrm{mmol})$ was then added to the stirring suspension dropwise at a rate to maintain reflux. After complete addition, the suspension was stirred for a further 2 hours at room temperature. The Grignard reagent was then filtered via canula before being added dropwise to a suspension of $\mathrm{ZnCl}_{2}(1.1 \mathrm{~g}, 8.07 \mathrm{mmol})$ held at $0{ }^{\circ} \mathrm{C}$. The suspension was warmed to room temperature and stirred for 15 mins. The suspension was then added, dropwise, to a solution of $\mathrm{PCl}_{3}$ $(2.11 \mathrm{~mL}, 30 \mathrm{mmol})$ in diethyl ether $(10 \mathrm{~mL})$ held at $45^{\circ} \mathrm{C}$. The solution was held at reflux for one hour before allowing to cool to room temperature. The solution was filtered via canula, and the residue washed with diethyl ether $(2 \times 20 \mathrm{~mL})$. Volatiles were removed from the filtrate in vacuo, and the crude product was distilled under vacuum $\left(80^{\circ} \mathrm{C}, 0.1\right.$ mbar) to give $\mathrm{C}_{6} \mathrm{H}_{5} \mathrm{CH}_{2} \mathrm{PCl}_{2}$ as a colourless oil $(0.77 \mathrm{~g}$, $40 \%)$.

${ }^{1} \mathrm{H}$ NMR $\left(500 \mathrm{MHz}, 298 \mathrm{~K}, \mathrm{C}_{6} \mathrm{D}_{6}\right): \delta$ 7.03-6.94 (m, 3H, Ar-H), 6.85-6.81 (m, 2H, Ar-H), $3.10\left(\mathrm{~d}, 2 \mathrm{H},{ }^{2} \mathrm{JH}_{\mathrm{H}}\right.$ $\left.\mathrm{P}=15.6 \mathrm{~Hz}, \mathrm{CH}_{2} \mathrm{PCl}_{2}\right) .{ }^{31} \mathrm{P}\left\{{ }^{1} \mathrm{H}\right\} \mathrm{NMR}\left(162 \mathrm{MHz}, 298 \mathrm{~K}, \mathrm{C}_{6} \mathrm{D}_{6}\right): \delta 179.0$. The values are in accordance to the literature. ${ }^{6}$

\section{$\left(\mathrm{NEt}_{2}\right)_{2} \mathrm{PCl}:$}

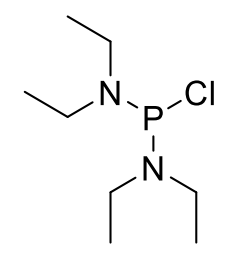

Following literature procedure, ${ }^{7}$ diethylamine $(21.2 \mathrm{~mL}, 205 \mathrm{mmol})$ in diethyl either $(15 \mathrm{~mL})$ was added to a diethyl ether $(80 \mathrm{~mL})$ solution of $\mathrm{PCl}_{3}(4.4 \mathrm{~mL}, 50.4 \mathrm{mmol})$ slowly at $-10^{\circ} \mathrm{C}$ before being warmed to room temperature and stirred for 30 mins. The solution was filtered via cannula and the resulting white precipitate was washed with diethyl ether $(50 \mathrm{~mL})$. Volatiles were removed in vacuo to give a crude oil, which was distilled under vacuum $\left(85^{\circ} \mathrm{C}, 1 \mathrm{mbar}\right)$ to give $\left(\mathrm{NEt}_{2}\right)_{2} \mathrm{PCl}$ as a colourless oil $(8.46 \mathrm{~g}, 80 \%)$. 
${ }^{1} \mathrm{H}$ NMR $\left(500 \mathrm{MHz}, 298 \mathrm{~K}, \mathrm{CDCl}_{3}\right): \delta 3.13\left(\mathrm{dq}, 8 \mathrm{H},{ }^{3} \mathrm{JH}_{\mathrm{H}}=6.9 \mathrm{~Hz},{ }^{3} \mathrm{JH}-\mathrm{P}=13.4 \mathrm{~Hz}, \mathrm{NCH}_{2} \mathrm{CH}_{3}\right), 1.10$ (t, $\left.12 \mathrm{H},{ }^{3} \mathrm{JH}_{\mathrm{H}}=7.1 \mathrm{~Hz}, \mathrm{NCH}_{2} \mathrm{CH}_{3}\right) .{ }^{31} \mathrm{P}\left\{{ }^{1} \mathrm{H}\right\} \mathbf{N M R}\left(162 \mathrm{MHz}, 298 \mathrm{~K}, \mathrm{CDCl}_{3}\right): \delta 159.8$. The values are in accordance to the literature. ${ }^{7}$

\section{4-OMe- ${ }_{6} \mathrm{H}_{4} \mathrm{PCl}_{2}$ :}<smiles>COc1ccc(P(=O)(Cl)c2ccccc2)cc1</smiles>

Following literature procedure, ${ }^{8}$ phosphorus trichloride $(1.75 \mathrm{~mL}, 20 \mathrm{mmol})$, anisole $(6.5 \mathrm{~mL}, 60 \mathrm{mmol})$, and bismuth trichloride $(0.315 \mathrm{~g}, 1 \mathrm{mmol})$ were added to a two-neck round bottom flask with a reflux condenser attached under nitrogen atmosphere. The mixture was heated at $120{ }^{\circ} \mathrm{C}$ for $3 \mathrm{~h}$, before bismuth trichloride $(0.315 \mathrm{~g}, 1 \mathrm{mmol})$ was again added and the mixture refluxed for a further $2 \mathrm{~h}$. Residual bismuth salts were precipitated with hexane $(20 \mathrm{~mL})$ and the product extracted via cannula filtration with hexane $(2 \times 20 \mathrm{~mL})$. Volatiles were removed in vacuo before the crude product was purified by vacuum distillation to give $4-\mathrm{OMe}-\mathrm{C}_{6} \mathrm{H}_{4} \mathrm{PCl}_{2}$ as a colourless oil. (1.00 g, $24 \%$ ).

${ }^{1} \mathrm{H}$ NMR $\left(500 \mathrm{MHz}, 298 \mathrm{~K}, \mathrm{C}_{6} \mathrm{D}_{6}\right): \delta$ 7.55-7.49 (m, 2H, Ar-H), 6.53-6.49 (m, 2H, Ar-H) 3.10 (s, 3H, $\mathrm{OMe}) .{ }^{31} \mathrm{P}\left\{{ }^{1} \mathrm{H}\right\} \mathrm{NMR}\left(162 \mathrm{MHz}, 298 \mathrm{~K}, \mathrm{C}_{6} \mathrm{D}_{6}\right): \delta 162.0$. The values are in accordance to the literature. ${ }^{9}$

\section{4- $\mathrm{CF}_{3}-\mathrm{C}_{6} \mathrm{H}_{4} \mathrm{PCl}_{2}$ :}<smiles>O=P(O)(c1ccccc1)c1ccc(C(F)(F)F)cc1</smiles>

Following literature procedure, ${ }^{10} \mathrm{n}$-Butyllithium $(2.38 \mathrm{M}$ in hexanes, $2.1 \mathrm{~mL}, 5 \mathrm{mmol}$ ) was added dropwise to a diethyl ether $(25 \mathrm{~mL})$ solution of 4 -bromobenzotrifluoride $(0.7 \mathrm{~mL}, 5 \mathrm{mmol})$ at $0{ }^{\circ} \mathrm{C}$, before being stirred for one hour at this temperature. ( $\left.\mathrm{NEt}_{2}\right)_{2} \mathrm{PCl}(1.1 \mathrm{~mL}, 5.25 \mathrm{mmol})$ was then added dropwise before the mixture was warmed to room temperature and stirred for a further two hours. The mixture was then cooled to $-78{ }^{\circ} \mathrm{C}$, and $\mathrm{HCl}$ in diethyl ether $(2 \mathrm{M}, 12.5 \mathrm{~mL})$ was added dropwise before the solution was warmed to room temperature and stirred overnight. Volatiles were removed in vacuo and the crude product was extracted in hexane $(25 \mathrm{~mL})$ via cannula filtration. Volatiles were removed in vacuo to give a crude oil. Distillation under vacuum $\left(65^{\circ} \mathrm{C}, 1 \mathrm{mbar}\right)$ gave $4-\mathrm{CF}_{3}-\mathrm{C}_{6} \mathrm{H}_{4} \mathrm{PCl}_{2}$ as a colourless oil $(0.66 \mathrm{~g}, 54 \%)$.

${ }^{1} \mathrm{H}$ NMR $\left(500 \mathrm{MHz}, 298 \mathrm{~K}, \mathrm{C}_{6} \mathrm{D}_{6}\right): \delta 7.26\left(\mathrm{dd}, 2 \mathrm{H},{ }^{3} \mathrm{~J}_{\mathrm{H}-\mathrm{H}}=7.9 \mathrm{~Hz},{ }^{3} \mathrm{~J}_{\mathrm{H}-\mathrm{P}}=9.0 \mathrm{~Hz}, \mathrm{Ar}-\mathrm{H}\right), 7.09\left(\mathrm{~d}, 2 \mathrm{H},{ }^{3} \mathrm{~J}_{\mathrm{H}-}\right.$ $\mathrm{H}=7.9 \mathrm{~Hz}, \mathrm{Ar}-H) .{ }^{31} \mathrm{P}\left\{{ }^{1} \mathrm{H}\right\}$ NMR $\left(162 \mathrm{MHz}, 298 \mathrm{~K}, \mathrm{C}_{6} \mathrm{D}_{6}\right): \delta$ 156.6. ${ }^{19} \mathrm{~F} \mathrm{NMR}\left(500 \mathrm{MHz}, 298 \mathrm{~K}, \mathrm{C}_{6} \mathrm{D}_{6}\right)$ : 63.1. The values are in accordance to the literature. ${ }^{10}$

\section{4-Me- $\mathrm{C}_{6} \mathrm{H}_{4} \mathrm{PCl}_{2}$ :}<smiles>Cc1ccc(P(=O)(Cl)c2ccc(C)cc2)cc1</smiles>

Following literature procedure, ${ }^{11} \mathrm{PCl}_{3}(5.24 \mathrm{~mL}, 60 \mathrm{mmol})$, toluene $(1.6 \mathrm{~mL}, 15 \mathrm{mmol})$ and aluminium trichloride $(2.65 \mathrm{~g}, 20 \mathrm{mmol})$ were added to a two-neck round bottom flask with a reflux condenser attached under inert atmosphere. The mixture was heated to $120^{\circ} \mathrm{C}$ upon which the mixture became homogeneous and $\mathrm{HCl}$ gas began to evolve. After 4 hours at reflux the heating was stopped and phosphorus oxychloride $(1.88 \mathrm{~mL}, 20 \mathrm{mmol})$ was added dropwise to the hot solution. The solution was filtered away from the newly formed precipitate was extracted with hot hexane (25 mL). Removal of volatiles in vacuo gave a crude oil, which was subsequently distilled under vacuum $\left(85^{\circ} \mathrm{C}, 1 \mathrm{mbar}\right)$ to give 4- $\mathrm{Me}_{-} \mathrm{C}_{6} \mathrm{H}_{4} \mathrm{PCl}_{2}$ as a colourless oil $(0.99 \mathrm{~g}, 34 \%)$. 
${ }^{1} \mathrm{H}$ NMR $\left(500 \mathrm{MHz}, 298 \mathrm{~K}, \mathrm{C}_{6} \mathrm{D}_{6}\right): \delta 7.50\left(\mathrm{dd}, 2 \mathrm{H},{ }^{3} \mathrm{JH}_{\mathrm{H}-\mathrm{H}}=7.3 \mathrm{~Hz},{ }^{3} \mathrm{~J}_{\mathrm{H}-\mathrm{P}}=10.0 \mathrm{~Hz}, \mathrm{Ar}-\mathrm{H}\right), 6.78\left(\mathrm{~d}, 2 \mathrm{H},{ }^{3} \mathrm{~J}_{\mathrm{H}-}\right.$ $\mathrm{H}=7.3 \mathrm{~Hz}, \mathrm{Ar}-\mathrm{H}), 1.93(\mathrm{~s}, 3 \mathrm{H}, \mathrm{Ar}-\mathrm{Me}) .{ }^{31} \mathrm{P}\left\{{ }^{1} \mathrm{H}\right\} \mathrm{NMR}\left(162 \mathrm{MHz}, 298 \mathrm{~K}, \mathrm{C}_{6} \mathrm{D}_{6}\right): \delta 162.2$. The values are in accordance to the literature. ${ }^{12}$

\section{4-F- $\mathrm{C}_{6} \mathrm{H}_{4} \mathrm{PCl}_{2}$ :}<smiles>Fc1ccc([TeH2])cc1</smiles>

Adapted from a literature procedure, ${ }^{13} \mathrm{PCl}_{3}(5.24 \mathrm{~mL}, 60 \mathrm{mmol})$, fluorobenzene $(1.41 \mathrm{~mL}, 15 \mathrm{mmol})$ and aluminium trichloride $(2.65 \mathrm{~g}, 20 \mathrm{mmol})$ were added to a two-neck round bottom flask with a reflux condenser attached under inert atmosphere. The mixture was heated to $95^{\circ} \mathrm{C}$ upon which the mixture became homogeneous and $\mathrm{HCl}$ gas began to evolve. After 4 hours at reflux the heating was stopped and phosphorus oxychloride $(1.88 \mathrm{~mL}, 20 \mathrm{mmol})$ was added dropwise to the hot solution. The solution was filtered away from the newly formed precipitate was extracted with hot hexane $(25 \mathrm{~mL})$. Removal of volatiles in vacuo gave a crude oil, which was subsequently distilled under vacuum $\left(65^{\circ} \mathrm{C}, 1 \mathrm{mbar}\right)$ to give $4-\mathrm{F}-\mathrm{C}_{6} \mathrm{H}_{4} \mathrm{PCl}_{2}$ as a colourless oil $(1.23 \mathrm{~g}, 42 \%)$.

${ }^{1} \mathrm{H}$ NMR $\left(500 \mathrm{MHz}, 298 \mathrm{~K}, \mathrm{C}_{6} \mathrm{D}_{6}\right): \delta 7.30$ (ddd, $\left.2 \mathrm{H},{ }^{3} \mathrm{~J}_{\mathrm{H}-\mathrm{F}}=8.5 \mathrm{~Hz},{ }^{3} \mathrm{~J}_{\mathrm{H}-\mathrm{H}}=7.6 \mathrm{~Hz},{ }^{4} \mathrm{JH}_{\mathrm{P}} \mathrm{P}=2.1 \mathrm{~Hz}, \mathrm{Ar}-\mathrm{H}\right)$, $6.55\left(\mathrm{ddd}, 2 \mathrm{H},{ }^{3} \mathrm{~J}_{\mathrm{H}-\mathrm{P}}=8.7 \mathrm{~Hz},{ }^{3} \mathrm{JH}_{\mathrm{H}}=7.6 \mathrm{~Hz},{ }^{4} \mathrm{JH}-\mathrm{F}=1.4 \mathrm{~Hz}, \operatorname{Ar}-\mathrm{H}\right) .{ }^{31} \mathrm{P}\left\{{ }^{1} \mathrm{H}\right\} \mathbf{N M R}\left(162 \mathrm{MHz}, 298 \mathrm{~K}, \mathrm{C}_{6} \mathrm{D}_{6}\right)$ : $\delta$ 158.9. ${ }^{19} \mathrm{~F}$ NMR $\left(500 \mathrm{MHz}, 298 \mathrm{~K}, \mathrm{C}_{6} \mathrm{D}_{6}\right):-105.5$.

\section{Dichloro(naphthalen-1-yl)phosphane:}<smiles>CCCCc1cccc2ccccc12</smiles>

Adapted from a literature procedure, ${ }^{14}$ activated magnesium turnings $(250 \mathrm{mg}, 10.3 \mathrm{mmol})$ were suspended in $10 \mathrm{~mL}$ THF in a Schenk tube equipped with a water-cooler reflux condenser. A THF (15 $\mathrm{mL})$ solution of 1-bromonaphthalene $(0.70 \mathrm{~mL}, 5 \mathrm{mmol})$ was added slowly before initiation of the Grignard reaction via heating to reflux, at which the reaction was held overnight. The reaction was cooled to room temperature and filtered via cannula, before cooling to $0^{\circ} \mathrm{C}$ and a diethyl ether solution $(10 \mathrm{~mL})$ of $\left(\mathrm{NEt}_{2}\right)_{2} \mathrm{PCl}(1.1 \mathrm{~mL}, 5.25 \mathrm{mmol})$ was added dropwise. The solution was then warmed to room temperature and stirred overnight. The solution was then cooled to $0{ }^{\circ} \mathrm{C}$ and $\mathrm{HCl}$ in diethyl ether $(2 \mathrm{M}$, $10 \mathrm{~mL}$ ) was added slowly. The solution was then warmed to room temperature and stirred for 30 mins, after which the solution was filtered through celite and the volatiles removed in vacuo to yield dichloro(naphthalen-1-yl)phosphane as a white solid (0.62 g, 54\%).

${ }^{1} \mathrm{H}$ NMR $\left(500 \mathrm{MHz}, 298 \mathrm{~K}, \mathrm{C}_{6} \mathrm{D}_{6}\right): \delta 8.55\left(\mathrm{~d}, 1 \mathrm{H},{ }^{3} \mathrm{JH}_{\mathrm{H}}=7.5 \mathrm{~Hz}\right), 7.98-7.89(\mathrm{~m}, 1 \mathrm{H}), 7.54-7.35(\mathrm{~m}, 2 \mathrm{H})$, 7.25-7.06 (m, 2H) 7.01-6.92 (m, 1H). ${ }^{31} \mathbf{P}$ NMR (162 MHz, $\left.298 \mathrm{~K}, \mathrm{C}_{6} \mathrm{D}_{6}\right): \delta 163.0$ (d, $\left.{ }^{3} \mathrm{JP}-\mathrm{H}=9.7 \mathrm{~Hz}\right)$.

The values are in accordance to the literature. ${ }^{14}$

\section{Dichloro(naphthalen-2-yl)phosphane:}<smiles>CCCCc1ccc2ccccc2c1</smiles> 
Adapted from a literature procedure, ${ }^{14}$ activated magnesium turnings $(250 \mathrm{mg}, 10.3 \mathrm{mmol}$ ) were suspended in $10 \mathrm{~mL}$ THF in a Schenk tube equipped with a water-cooler reflux condenser. A THF (15 $\mathrm{mL}$ ) solution of 2-bromonaphthalene $(1.04 \mathrm{~g}, 5 \mathrm{mmol})$ was added slowly before initiation of the Grignard reaction via heating to reflux, at which the reaction was held overnight. The reaction was cooled to room temperature and filtered via cannula, before cooling to $0^{\circ} \mathrm{C}$ and a diethyl ether solution $(10 \mathrm{~mL})$ of $\left(\mathrm{NEt}_{2}\right)_{2} \mathrm{PCl}(1.1 \mathrm{~mL}, 5.25 \mathrm{mmol})$ was added dropwise. The solution was then warmed to room temperature and stirred overnight. The solution was then cooled to $0{ }^{\circ} \mathrm{C}$ and $\mathrm{HCl}$ in diethyl ether $(2 \mathrm{M}$, $10 \mathrm{~mL}$ ) was added slowly. The solution was then warmed to room temperature and stirred for 30 mins, after which the solution was filtered through celite and the volatiles removed in vacuo to yield dichloro(naphthalen-2-yl)phosphane as a pale yellow solid $(0.81 \mathrm{~g}, 71 \%)$.

${ }^{1} \mathrm{H}$ NMR $\left(500 \mathrm{MHz}, 298 \mathrm{~K}, \mathrm{C}_{6} \mathrm{D}_{6}\right): \delta$ 7.87-7.82 (m, $\left.1 \mathrm{H}\right), 7.78(\mathrm{~d}, 1 \mathrm{H}, \mathrm{J}=14.2 \mathrm{~Hz}), 7.49-7.44(\mathrm{~m}, 1 \mathrm{H})$, 7.43-7.35 (m, 2H) 7.21-7.12 (m, $1 \mathrm{H}) .{ }^{31} \mathrm{P}\left\{{ }^{1} \mathrm{H}\right\}$ NMR $\left(162 \mathrm{MHz}, 298 \mathrm{~K}, \mathrm{C}_{6} \mathrm{D}_{6}\right): \delta 160.1$. The values are in accordance to the literature. ${ }^{15}$

\section{Dichloro(phenanthren-9-yl)phosphane:}<smiles>CCCCCc1cc2ccccc2c2ccccc12</smiles>

Adapted from a literature procedure, ${ }^{14}$ activated magnesium turnings $(250 \mathrm{mg}, 10.3 \mathrm{mmol})$ were suspended in $10 \mathrm{~mL}$ THF in a Schenk tube equipped with a water-cooler reflux condenser. A THF (15 $\mathrm{mL}$ ) solution of 1-bromonaphthalene $(1.29 \mathrm{~g}, 5 \mathrm{mmol})$ was added slowly before initiation of the Grignard reaction via heating to reflux, at which the reaction was held overnight. The reaction was cooled to room temperature and filtered via cannula, before cooling to $0^{\circ} \mathrm{C}$ and a diethyl ether solution $(10 \mathrm{~mL})$ of $\left(\mathrm{NEt}_{2}\right)_{2} \mathrm{PCl}(1.1 \mathrm{~mL}, 5.25 \mathrm{mmol})$ was added dropwise. The solution was then warmed to room temperature and stirred overnight. The solution was then cooled to $0{ }^{\circ} \mathrm{C}$ and $\mathrm{HCl}$ in diethyl ether $(2 \mathrm{M}$, $10 \mathrm{~mL}$ ) was added slowly. The solution was then warmed to room temperature and stirred for 30 mins, after which the solution was filtered through celite and the volatiles removed in vacuo to yield dichloro(phenanthren-9-yl)phosphane as a pale yellow solid (0.60 g, 43\%).

${ }^{1} \mathrm{H}$ NMR $\left(500 \mathrm{MHz}, 298 \mathrm{~K}, \mathrm{C}_{6} \mathrm{D}_{6}\right): \delta 8.78\left(\mathrm{~d}, 1 \mathrm{H},{ }^{3} \mathrm{~J}_{\mathrm{H}-\mathrm{H}}=7.8 \mathrm{~Hz}\right), 8.70(\mathrm{~m}, 2 \mathrm{H}), 8.54\left(\mathrm{~d}, 1 \mathrm{H},{ }^{3} \mathrm{JH}_{\mathrm{P}} \mathrm{P}=14.1\right.$ $\mathrm{Hz}), 8.02\left(\mathrm{~d}, 1 \mathrm{H},{ }^{3} \mathrm{JH}_{\mathrm{H}-\mathrm{H}}=7.9 \mathrm{~Hz}\right), 7.77(\mathrm{~m}, 4 \mathrm{H}) .{ }^{31} \mathrm{P}$ NMR $\left(162 \mathrm{MHz}, 298 \mathrm{~K}, \mathrm{C}_{6} \mathrm{D}_{6}\right): \delta 162.4\left(\mathrm{~d},{ }^{3} \mathrm{JP}-\mathrm{H}=\right.$ $14.5 \mathrm{~Hz}$ ). The values are in accordance to the literature. ${ }^{14}$

\section{Dichloro(pyren-1-yl)phosphane:}<smiles>CCCCc1ccc2ccc3cccc4ccc1c2c34</smiles>

Adapted from a literature procedure, ${ }^{14} n$-Butyllithium (1.56 mL, $3.9 \mathrm{mmol}, 2.5 \mathrm{M}$ solution in hexanes) was added dropwise to a THF/diethyl ether solution $(16 \mathrm{~mL}, 1: 1 \mathrm{v} / \mathrm{v})$ held at $-78^{\circ} \mathrm{C}$. A THF/diethyl ether solution $(8 \mathrm{~mL}, 1: 1 \mathrm{v} / \mathrm{v})$ of 1 -bromopyrene $(1.1 \mathrm{~g}, 3.9 \mathrm{mmol})$ was then added dropwise, after which the solution was stirred for 30 mins at this temperature, before being allowed to warm to room temperature and stirred for a further 20 mins. The reaction was cooled to $-78^{\circ} \mathrm{C}$ and a THF/diethyl ether solution (5 $\mathrm{mL}, 1: 1 \mathrm{v} / \mathrm{v})$ of $\left(\mathrm{NEt}_{2}\right)_{2} \mathrm{PCl}(1.1 \mathrm{~mL}, 5.25 \mathrm{mmol})$ was added dropwise. The solution was then warmed to room temperature and stirred overnight. The solution was then cooled to $-78{ }^{\circ} \mathrm{C}$ and $\mathrm{HCl}$ in diethyl ether $(2 \mathrm{M}, 10 \mathrm{~mL})$ was added slowly. The solution was then warmed to room temperature and stirred for 30 mins, after which the solution was filtered through celite and the volatiles removed in vacuo to yield dichloro(naphthalen-1-yl)phosphane as a yellow solid (0.48 g, 40\%). 
${ }^{1} \mathrm{H}$ NMR $\left(500 \mathrm{MHz}, 298 \mathrm{~K}, \mathrm{C}_{6} \mathrm{D}_{6}\right): \delta 8.77\left(\mathrm{dd}, 1 \mathrm{H},{ }^{3} \mathrm{~J}_{\mathrm{H}-\mathrm{H}}=9.1 \mathrm{~Hz},{ }^{4} \mathrm{JH}-\mathrm{P}=3.0 \mathrm{~Hz}\right), 8.73\left(\mathrm{dd}, 1 \mathrm{H},{ }^{3} \mathrm{JH}_{\mathrm{H}}=\right.$ $\left.8.1 \mathrm{~Hz},{ }^{4} \mathrm{JH}_{\mathrm{P}}=7.0 \mathrm{~Hz}\right), 8.16(\mathrm{~m}, 2 \mathrm{H}), 8.23(\mathrm{~m}, 3 \mathrm{H}), 8.04(\mathrm{~m}, 2 \mathrm{H}) .{ }^{31} \mathrm{P} \mathbf{N M R}\left(162 \mathrm{MHz}, 298 \mathrm{~K}, \mathrm{C}_{6} \mathrm{D}_{6}\right): \delta$ $163.6\left(\mathrm{~d},{ }^{3} \mathrm{JP}-\mathrm{H}=14.5 \mathrm{~Hz}\right)$. The values are in accordance to the literature. ${ }^{14}$

\section{General Procedure for the Synthesis of Secondary Phosphines via Reduction of Secondary Phosphine Oxides}

In a scale up from literature procedure, ${ }^{16}$ phosphine oxide $(1 \mathrm{mmol})$ was added to a Schlenk tube containing acetonitrile $(4 \mathrm{~mL})$. HBpin $(2 \mathrm{mmol})$ was then added before the reaction was stirred for $20 \mathrm{~h}$ at $60{ }^{\circ} \mathrm{C}(1.1 \mathrm{mmol} \mathrm{HBpin}, 2 \mathrm{~h}$ at room temperature $) .{ }^{\mathrm{a}}$ Degassed isopropanol $(0.8 \mathrm{~mL})$ was then added 
before the volatiles were removed in vacuo. The residue was dissolved in toluene before being filtered through an alumina plug. The solvent was again removed in vacuo to yield the secondary phosphine product.

\section{Synthesised Secondary Phosphines}

$\mathrm{HP}\left(4-\mathrm{MeC}_{6} \mathrm{H}_{4}\right)_{2}$ : 
<smiles>CCc1ccc(P)cc1</smiles>

Yield: $110 \mathrm{mg}, 51 \%$. ${ }^{1} \mathrm{H}$ NMR $\left(300 \mathrm{MHz}, 298 \mathrm{~K}, \mathrm{CD}_{3} \mathrm{CN}\right): \delta 7.37$ (dd, $4 \mathrm{H},{ }^{3} \mathrm{JH}_{\mathrm{H}-\mathrm{H}}=7.7 \mathrm{~Hz},{ }^{3} \mathrm{JH}_{\mathrm{H}-\mathrm{P}}=8.1 \mathrm{~Hz}$ Ar-H), $7.15\left(\mathrm{~d}, 4 \mathrm{H},{ }^{3} \mathrm{JH}_{-\mathrm{H}}=7.7 \mathrm{~Hz}, \mathrm{Ar}-\mathrm{H}\right), 5.14(\mathrm{~d}, 1 \mathrm{H}, 219.0 \mathrm{~Hz},-\mathrm{PH}), 2.30$ (s, 6H, Ar-Me). ${ }^{31} \mathrm{P}$ NMR (162 $\left.\mathrm{MHz}, 298 \mathrm{~K}, \mathrm{CD}_{3} \mathrm{CN}\right): \delta-41.8\left(\mathrm{~d},{ }^{1} \mathrm{JP}-\mathrm{H}=220.1 \mathrm{~Hz}\right)$. The values are in accordance to the literature. ${ }^{16}$

\section{$\mathrm{HP}\left(4-\mathrm{OMeC}_{6} \mathrm{H}_{4}\right)_{2}$ :}<smiles>COc1ccc(Pc2ccccc2)cc1</smiles>

Yield: $168 \mathrm{mg}, 68 \% .{ }^{1} \mathrm{H}$ NMR $\left(300 \mathrm{MHz}, 298 \mathrm{~K}, \mathrm{CD}_{3} \mathrm{CN}\right): \delta$ 7.38-7.45 (m, 4H, Ar- $\left.\mathrm{H}\right), 6.86-6.93(\mathrm{~m}, 4 \mathrm{H}$, Ar- $H$ ), $5.13(\mathrm{~d}, 1 \mathrm{H}, 218.4 \mathrm{~Hz},-\mathrm{PH}), 3.76(\mathrm{~s}, 6 \mathrm{H},-\mathrm{OMe}) .{ }^{31} \mathrm{P}$ NMR $\left(162 \mathrm{MHz}, 298 \mathrm{~K}, \mathrm{CD}_{3} \mathrm{CN}\right): \delta-44.4$ (d, $\left.{ }^{1} \mathrm{JP}-\mathrm{H}=218.0 \mathrm{~Hz}\right)$. The values are in accordance to the literature..$^{16}$

\section{$\mathrm{HP}\left(2-\mathrm{OMeC}_{6} \mathrm{H}_{4}\right)_{2}$ :}<smiles>COc1ccccc1Pc1ccccc1</smiles>

Yield: $131 \mathrm{mg}, 53 \% .{ }^{1} \mathrm{H}$ NMR (300 MHz, $\left.298 \mathrm{~K}, \mathrm{CD}_{3} \mathrm{CN}\right): \delta$ 7.13-7.38 (m, 4H, Ar- $\left.H\right), 6.85-7.01(\mathrm{~m}, 4 \mathrm{H}$, Ar-H), $5.10(\mathrm{~d}, 1 \mathrm{H}, 225.3 \mathrm{~Hz},-\mathrm{PH}), 3.80(\mathrm{~s}, 3 \mathrm{H},-\mathrm{OMe}) .{ }^{31} \mathrm{P}$ NMR (162 MHz, $\left.298 \mathrm{~K}, \mathrm{CD}_{3} \mathrm{CN}\right): \delta-72.3$ (d, $\left.{ }^{1} \mathrm{JP}_{\mathrm{H}}=225.1 \mathrm{~Hz}\right)$. The values are in accordance to the literature..$^{16}$

$\mathrm{HP}\left(4-\mathrm{ClC}_{6} \mathrm{H}_{4}\right)_{2}$ :<smiles>Pc1ccc(Cl)cc1</smiles>

Yield: 84 mg, 33\%. ${ }^{1} \mathrm{H}$ NMR (300 MHz, $\left.298 \mathrm{~K}, \mathrm{CD}_{3} \mathrm{CN}\right): \delta$ 7.41-7.51 (m, 4H, Ar- H), 7.30-7.40 (m, 4H, Ar-H), 5.21 (d, $1 \mathrm{H}, 223.9 \mathrm{~Hz}, \mathrm{PH}) .{ }^{31} \mathrm{P}$ NMR (162 MHz, $\left.298 \mathrm{~K}, \mathrm{CD}_{3} \mathrm{CN}\right): \delta-43.0$ (d, $\left.{ }^{1} \mathrm{JP}-\mathrm{H}=223.5 \mathrm{~Hz}\right)$. The values are in accordance to the literature. ${ }^{16}$

$\mathrm{HP}\left(4-\mathrm{FC}_{6} \mathrm{H}_{4}\right)_{2}$ :<smiles>Fc1ccc(-c2ccccc2)cc1</smiles>

Yield: $140 \mathrm{mg}, 57 \% .{ }^{1} \mathrm{H}$ NMR (300 MHz, $\left.298 \mathrm{~K}, \mathrm{CDCl}_{3}\right): \delta 7.13(\mathrm{~m}, 4 \mathrm{H}, \mathrm{Ar}-H), 6.76(\mathrm{~m}, 4 \mathrm{H}, \mathrm{Ar}-H), 5.06$ (d, $1 \mathrm{H}, 216.4 \mathrm{~Hz}, \mathrm{PH}) .{ }^{31} \mathrm{P}$ NMR $\left(162 \mathrm{MHz}, 298 \mathrm{~K}, \mathrm{CD}_{3} \mathrm{CN}\right): \delta-43.3\left(\mathrm{~d},{ }^{1} \mathrm{JP}-\mathrm{H}=215.5 \mathrm{~Hz}\right)$. The values are in accordance to the literature. ${ }^{16}$

$\mathrm{HP}\left(4-\mathrm{CF}_{3} \mathrm{C}_{6} \mathrm{H}_{3}\right)_{2}$ : 


$$
\left(\mathrm{F}_{3} \mathrm{C}\right)_{2}^{\mathrm{PH}}
$$

Yield: 97mg, 55\%. ${ }^{1} \mathrm{H}$ NMR $\left(300 \mathrm{MHz}, 298 \mathrm{~K}, \mathrm{CD}_{3} \mathrm{CN}\right): \delta 8.12-8.16\left(\mathrm{~d}, 4 \mathrm{H},{ }^{3} \mathrm{~J}_{\mathrm{H}-\mathrm{H}}=7.8 \mathrm{~Hz}, \mathrm{Ar}-\mathrm{H}\right), 7.09$ $\left(\mathrm{dd}, 4 \mathrm{H},{ }^{3} \mathrm{JH}_{\mathrm{H}}=7.9 \mathrm{~Hz},{ }^{3} \mathrm{JH}_{\mathrm{H}-\mathrm{P}}=8.4 \mathrm{~Hz}, \mathrm{Ar}-\mathrm{H}\right) 4.94(\mathrm{~d}, 1 \mathrm{H}, 219.0 \mathrm{~Hz}, \mathrm{PH}) .{ }^{31} \mathbf{P}$ NMR $(162 \mathrm{MHz}, 298 \mathrm{~K}$, $\left.\mathrm{CD}_{3} \mathrm{CN}\right): \delta-41.0\left(\mathrm{~d},{ }^{1} \mathrm{JP}-\mathrm{H}=222.3 \mathrm{~Hz}\right)$. The values are in accordance to the literature. ${ }^{17}$ 


\section{General Procedure for the Formation of Cyclopolyphosphines}

For aryldichlorophosphines (1a-1i): Dichlorophosphine $(0.5 \mathrm{mmol}, 1 \mathrm{eq}$.$) was added to a J-Young$ NMR tube along with $\mathrm{C}_{6} \mathrm{D}_{6}(0.6 \mathrm{~mL})$. Diisopropylphosphine $(1.0 \mathrm{mmol}, 180 \mu \mathrm{L}, 2 \mathrm{eq}$.) was then added. The reaction was then left for 10 mins at RT, before the working up by one of two methods:

A: (Products 1a-1g): Solvent and residual chlorophosphine species were removed via vacuum distillation $\left(120^{\circ} \mathrm{C}, 1 \mathrm{mbar}\right)$. The products were re-dissolved in dichloromethane and transferred to a vial, after which removal of volatiles yielded the pure cyclopolyphosphine product.

B: (Products $1 \mathrm{~h}$ and 1i): Products were isolated by filtration, washed with benzene $(2 \times 1.5 \mathrm{~mL})$, and dried under vacuum.

For alkyldichlorophosphines (2a-2f): $\mathrm{Fe}(\mathrm{acac})_{3}(18 \mathrm{mg}, 10 \mathrm{~mol} \%)$ was added to a J-Young NMR tube in $0.6 \mathrm{~mL} \mathrm{C}_{6} \mathrm{D}_{6}$. The corresponding dichlorophosphine $(0.5 \mathrm{mmol}, 1 \mathrm{eq}$.) was then added before the addition of diisopropylphosphine $(1.0 \mathrm{mmol}, 180 \mu \mathrm{L}, 2$ eq.). After 10 mins at RT, products were isolated by one of two methods:

A: (Products $\mathbf{2 b}, \mathbf{2 d}-\mathbf{2 f})$ : The reaction mixture was passed through a silica plug, eluting with toluene, before residual chlorophosphine species were removed via vacuum distillation $\left(120^{\circ} \mathrm{C}, 1 \mathrm{mbar}\right)$. The products were re-dissolved in dichloromethane and transferred to a vial, after which removal of volatiles yielded the pure cyclopolyphosphine product.

B: (Products $\mathbf{2 a}$ and $\mathbf{2 c}$ ): Products were isolated via removal of volatiles and subsequent washing with $-78^{\circ} \mathrm{C}$ THF $(2 \times 1.5 \mathrm{~mL})$, before again being dried under vacuum.

On the differences in conversion and isolated yield in products 2c-2f: Presumed degradation on

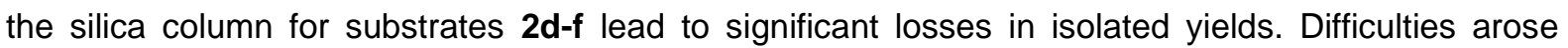
separating $\mathbf{2 c}$ from residual $\mathrm{Fe}$ species as the silica column was not applicable due to solubility of product, therefore washing with THF at $-78 \mathrm{C}$ was the only way found suitable despite yield loss from the washing.

\section{NOTE ON NMR SPECTRA:}

The solution-phase ${ }^{31} \mathrm{P}$ NMR spectra of most cyclic pentamers (products $\mathbf{1 a}-\mathbf{e}, \mathbf{1} \mathbf{g}, \mathbf{2 b}, \mathbf{2 e}$ and $\mathbf{2 f}$ ) show minimal amounts of the corresponding tetrameric $\left((\mathrm{PR})_{4}\right)$ and hexameric $\left((\mathrm{PR})_{6}\right)$ oligomers, appearing as singlets upfield of the signal for the pentamer ((PR $)_{4}$ most upfield). These species are labelled as such in relevant ${ }^{31} \mathrm{P}$ NMR spectra. The formation of small quantities of these four- and sixmembered rings in solution is consistent with previous literature reports of cyclic pentamers. ${ }^{18}$ Relative integrals of all species are also given in relevant ${ }^{31} \mathrm{P}$ NMR spectra and contributions to isolated yields by $(\mathrm{PR})_{4}$ and $(\mathrm{PR})_{6}$ calculated from this are shown. It is noteworthy that signals from these oligomers will also be present in ${ }^{1} \mathrm{H}$ and ${ }^{13} \mathrm{C}$ NMR spectra. 


\section{Spectroscopic data Figure 1}

1a:<smiles>c1ccc(-p2p(-c3ccccc3)p(-c3ccccc3)p(-c3ccccc3)p2-c2ccccc2)cc1</smiles>

Isolated as a white solid in $89 \%$ total yield as $85.4 \% \mathrm{P}_{5} \mathrm{R}_{5}, 0.7 \% \mathrm{P}_{6} \mathrm{R}_{6}, 2.9 \% \mathrm{P}_{4} \mathrm{R}_{4} .{ }^{1} \mathrm{H}$ NMR $(500 \mathrm{MHz}$, $\left.298 \mathrm{~K}, \mathrm{C}_{6} \mathrm{D}_{6}\right): \delta 8.06(\mathrm{~d}, 5 \mathrm{H}, \mathrm{J}=7.4 \mathrm{~Hz}), 7.37(\mathrm{~d}, 5 \mathrm{H}, \mathrm{J}=7.4 \mathrm{~Hz}), 7.11-7.00(\mathrm{~m}, 10 \mathrm{H}), 6.87-6.82(\mathrm{~m}$, 5H). ${ }^{31} \mathbf{P}$ NMR (162 MHz, $\left.298 \mathrm{~K}, \mathrm{C}_{6} \mathrm{D}_{6}\right): \delta-0.2--5.9(\mathrm{~m}) .{ }^{13} \mathrm{C}\left\{{ }^{1} \mathrm{H}\right\} \mathbf{N M R}\left(101 \mathrm{MHz}, 298 \mathrm{~K}, \mathrm{C}_{6} \mathrm{D}_{6}\right): \delta$ 134.2-133.7 (m), 133.0-132.4 (m), 128.8-128.5 (m), $128.4(\mathrm{~d})$. The values are in accordance to the literature..$^{19}$ HRMS: $541.0713 \mathrm{~m} / \mathrm{z}[\mathrm{M}+\mathrm{H}]^{+}$(calculated: 541.0717 ). Melting point: $150-152{ }^{\circ} \mathrm{C}$ (Lit. 149$\left.150{ }^{\circ} \mathrm{C}\right) .^{20}$

${ }^{1} \mathrm{H}$ NMR $\left(500 \mathrm{MHz}, 298 \mathrm{~K}, \mathrm{C}_{6} \mathrm{D}_{6}\right)$ :

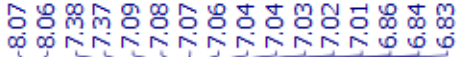
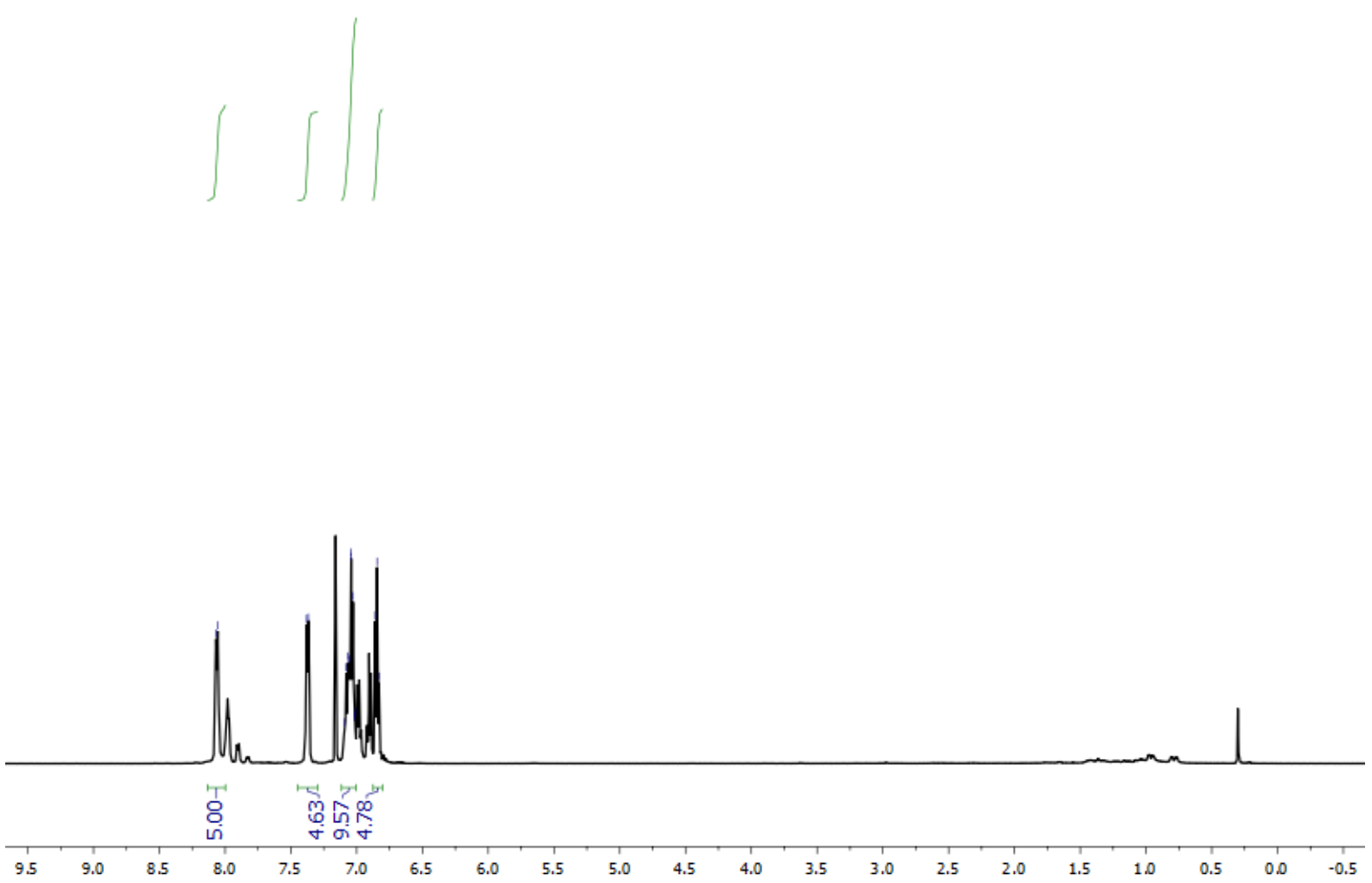
${ }^{31}$ P NMR (162 MHz, $\left.298 \mathrm{~K}, \mathrm{C}_{6} \mathrm{D}_{6}\right)$ :

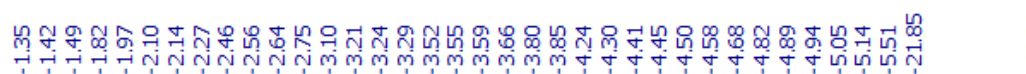

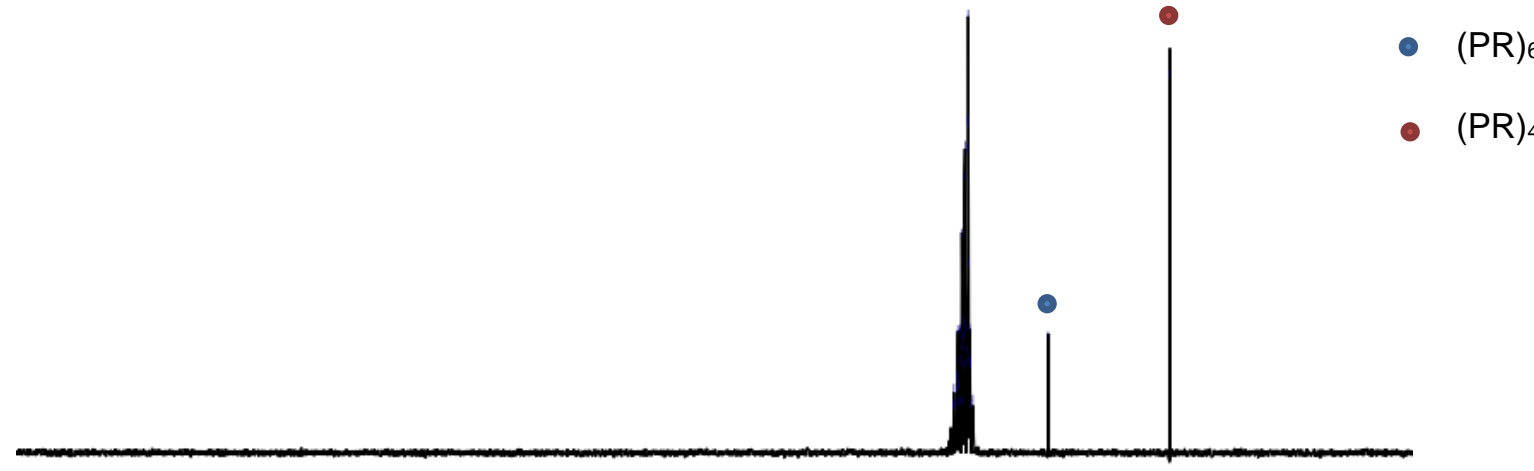

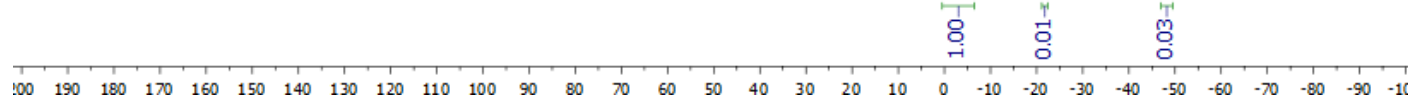

${ }^{13} \mathbf{C}\left\{{ }^{1} \mathbf{H}\right\}$ NMR $\left(101 \mathrm{MHz}, 298 \mathrm{~K}, \mathrm{C}_{6} \mathrm{D}_{6}\right):$

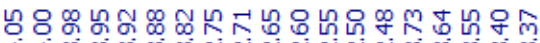

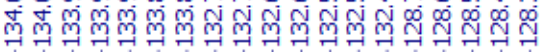

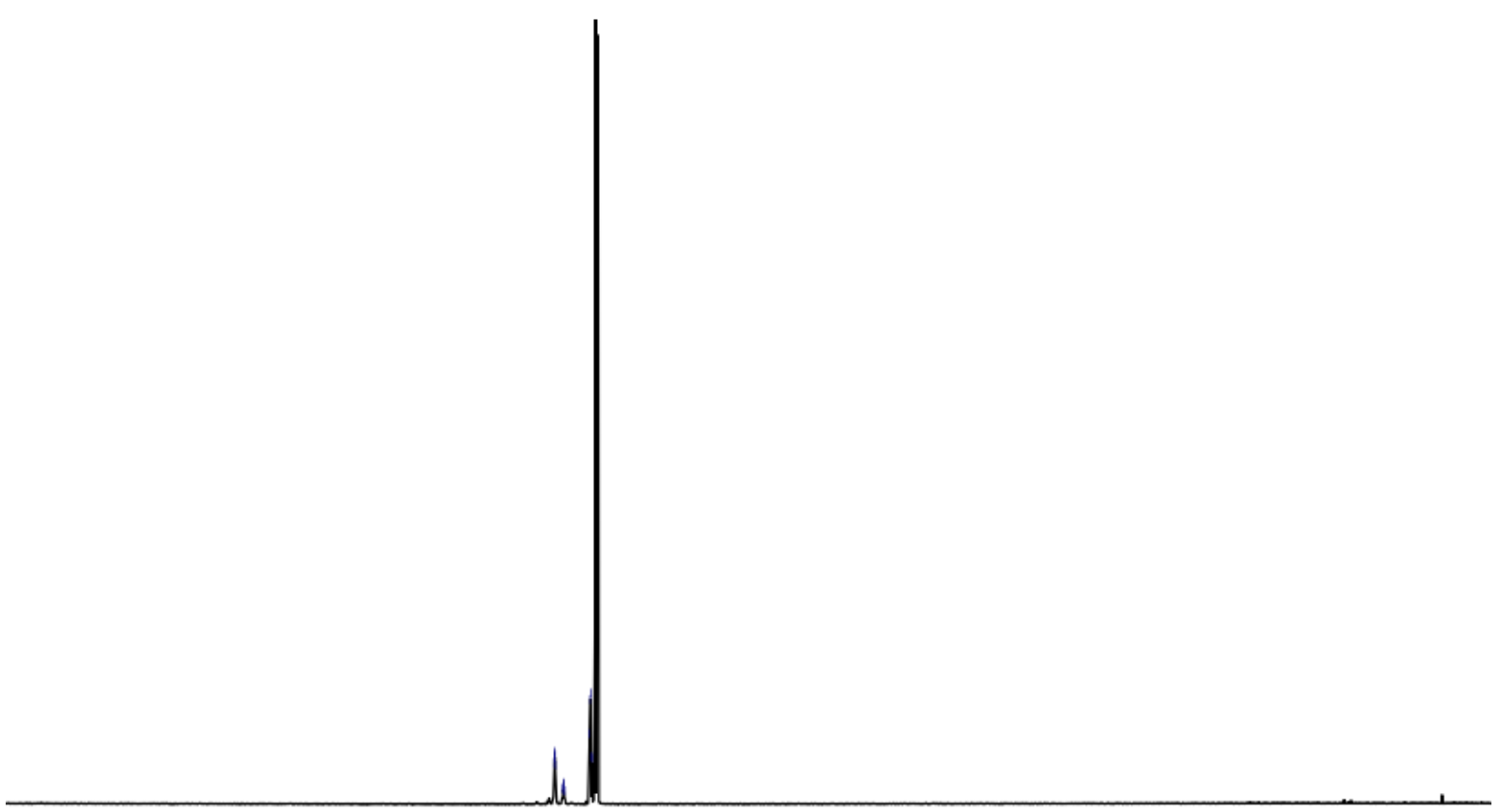


1b:<smiles>Cc1ccc(-p2p(-c3ccc(C)cc3)p(-c3ccc(C)cc3)p(-c3ccc(C)cc3)p2-c2ccc(C)cc2)cc1</smiles>

Isolated as a white solid in $83 \%$ total yield as $81.4 \% \mathrm{P}_{5} \mathrm{R}_{5}, 0.5 \% \mathrm{P}_{6} \mathrm{R}_{6}, 1.1 \% \mathrm{P}_{4} \mathrm{R}_{4} .{ }^{1} \mathrm{H}$ NMR $(500 \mathrm{MHz}$, $\left.298 \mathrm{~K}, \mathrm{C}_{6} \mathrm{D}_{6}\right): \delta$ 8.16-7.88 (m, 6H, Ar- $H$ ), 7.49-7.28 (m, 4H, Ar- $H$ ), 7.01-6.68 (m, 10H, Ar- H), 2.10-1.86 $(\mathrm{m}, 15 \mathrm{H}, \mathrm{Ar}-\mathrm{Me}) .{ }^{31} \mathbf{P}$ NMR $\left(162 \mathrm{MHz}, 298 \mathrm{~K}, \mathrm{C}_{6} \mathrm{D}_{6}\right): \delta-0.6--11.4(\mathrm{~m}) .{ }^{13} \mathrm{C}\left\{{ }^{1} \mathrm{H}\right\}$ NMR $(101 \mathrm{MHz}, 298 \mathrm{~K}$, $\left.\mathrm{C}_{6} \mathrm{D}_{6}\right): \delta$ 137.7-137.3 (m, Ar-C), 133.5-132.8 (m, Ar-C), 128.6-128.1 (m, Ar-C), 127.7-127.4 (m, Ar-C), 19.9-19.6 (m, Ar-Me). HRMS: $611.1495 \mathrm{~m} / \mathrm{z}[\mathrm{M}+\mathrm{H}]^{+}$(calculated: 611.1499$)$. Melting point: $159-161^{\circ} \mathrm{C}$. IR: (ATR, 298 K): 3011 (w), 2918 (w), 2861 (w), 1900 (vw), 1589 (w), 1491 (s), 1445 (w), 1393 (w), 1306 (w), 1261 (w), 1185 (s), 1101 (s), 1082 (s), 1017 (s), 797 (vs), 774 (s), 746 (w), 705 (w), 691 (s) $\mathrm{cm}^{-1}$.

${ }^{1} \mathrm{H}$ NMR $\left(500 \mathrm{MHz}, 298 \mathrm{~K}, \mathrm{C}_{6} \mathrm{D}_{6}\right)$ :

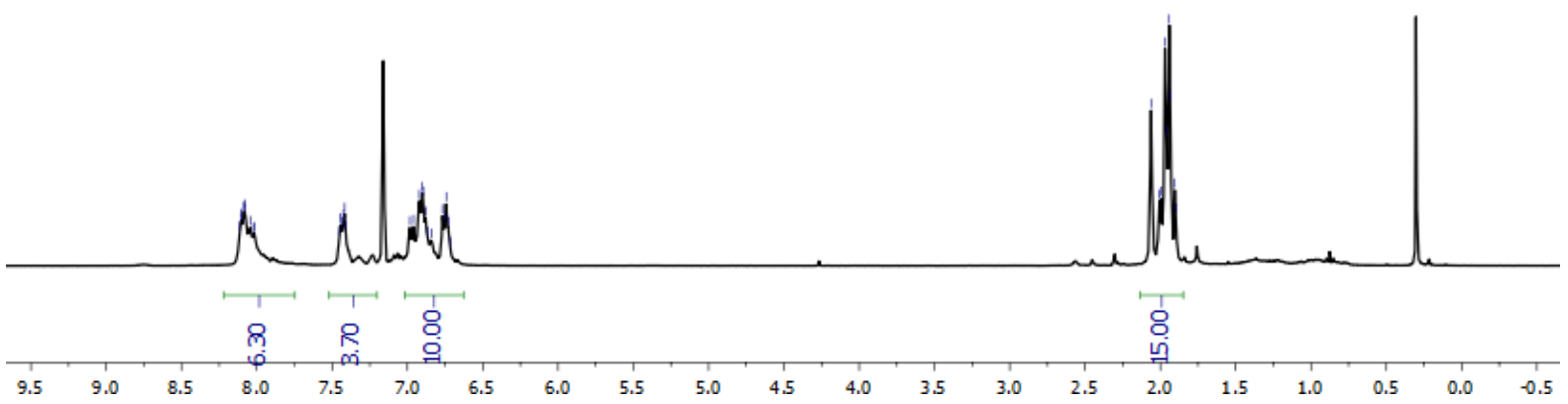


${ }^{31}$ P NMR (162 MHz, 298K, C6 $\left.\mathrm{D}_{6}\right)$ :

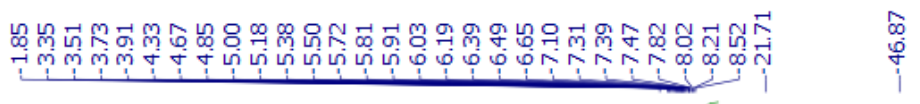

- $(\mathrm{PR})_{6}$

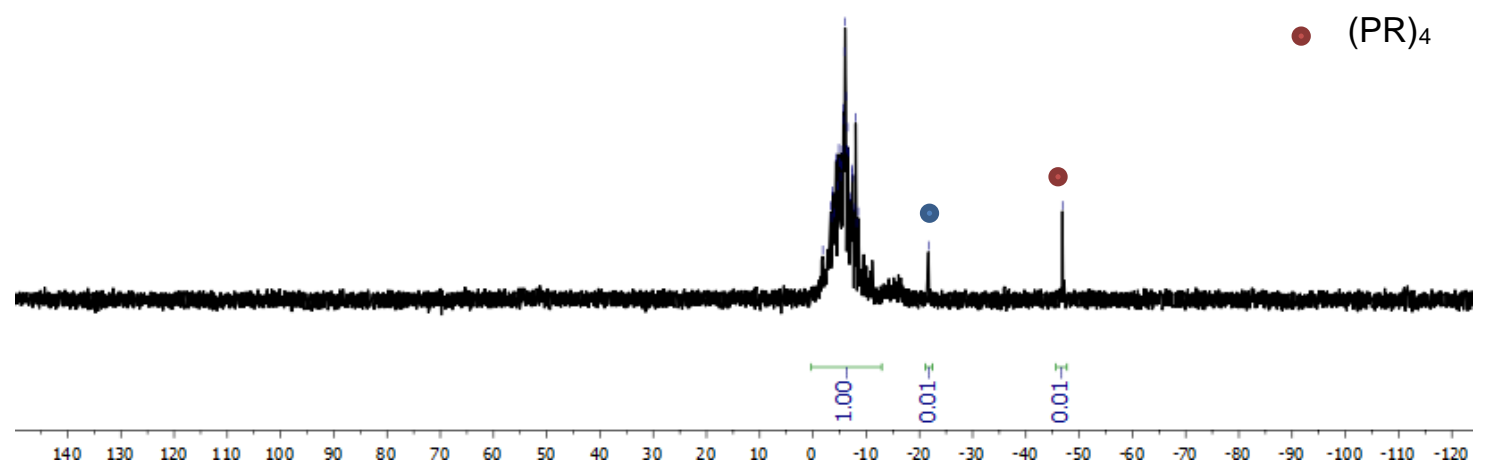

${ }^{13} \mathrm{C}\left\{{ }^{1} \mathrm{H}\right\}$ NMR $\left(101 \mathrm{MHz}, 298 \mathrm{~K}, \mathrm{C}_{6} \mathrm{D}_{6}\right):$

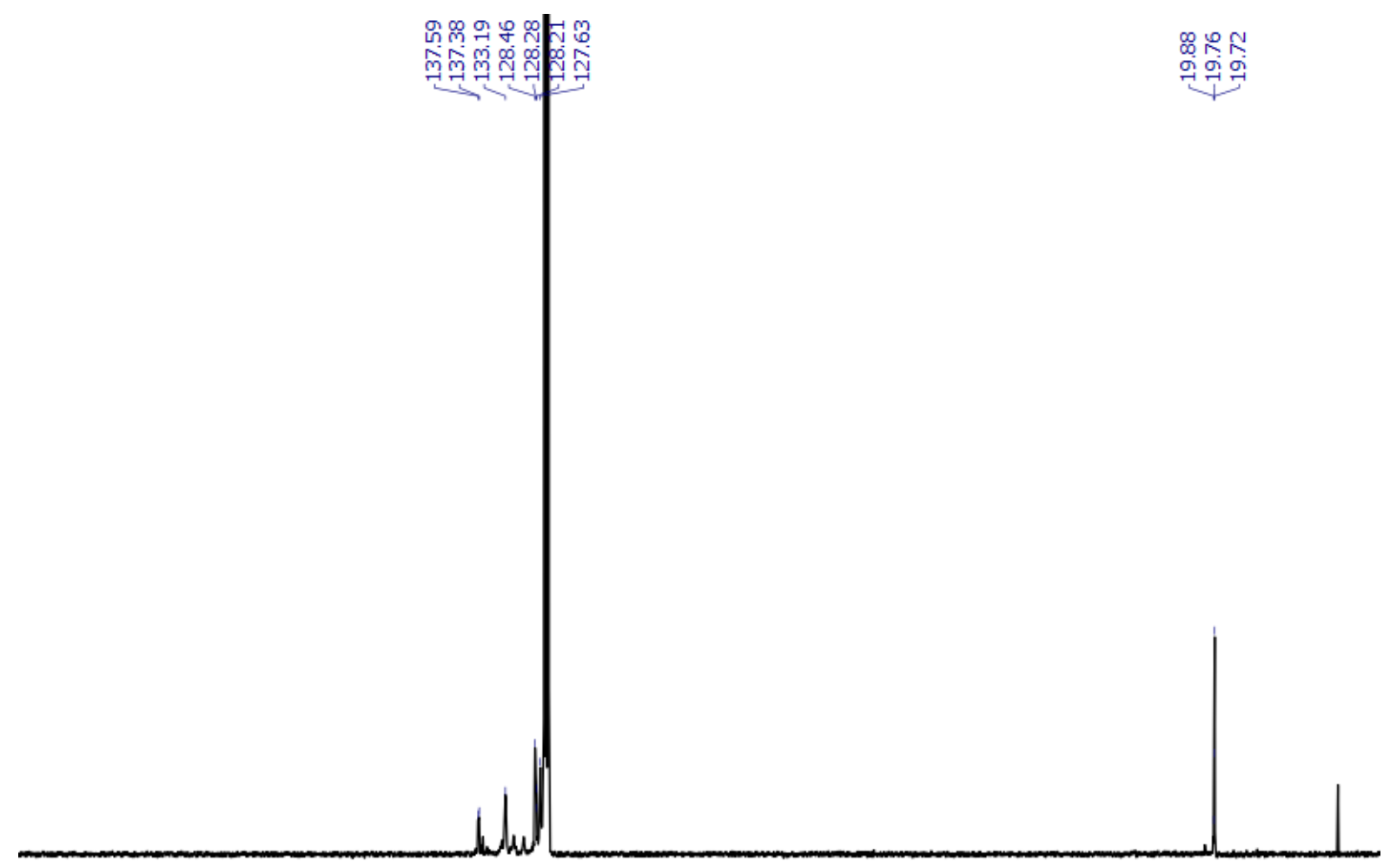

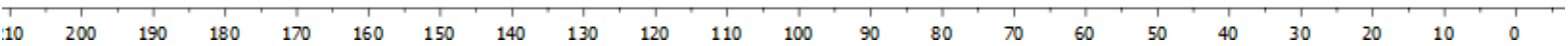


1c:<smiles>COc1ccc(-p2p(-c3ccc(OC)cc3)p(-c3ccc(OC)cc3)p(-c3ccc(OC)cc3)p2-c2ccc(OC)cc2)cc1</smiles>

Isolated as a yellow solid in $94 \%$ total yield as $84.5 \% \mathrm{P}_{5} \mathrm{R}_{5}, 5.0 \% \mathrm{P}_{6} \mathrm{R}_{6}, 4.5 \% \mathrm{P}_{4} \mathrm{R}_{4} .{ }^{1} \mathrm{H}$ NMR $(500 \mathrm{MHz}$, $\left.298 \mathrm{~K}, \mathrm{CD}_{2} \mathrm{Cl}_{2}\right): \delta$ 7.83-7.71 (m, 6H, Ar-H), 7.18-7.13 (m, 3H, Ar-H), 6.92-6.87 (m, 7H, Ar-H), $6.70(\mathrm{~d}$, $4 \mathrm{H}, \mathrm{J}=8.4 \mathrm{~Hz}, \mathrm{Ar}-\mathrm{H}), 3.85-3.75(\mathrm{~m}, 15 \mathrm{H}, \mathrm{O}-\mathrm{Me}) .{ }^{31} \mathrm{P}$ NMR $\left(162 \mathrm{MHz}, 298 \mathrm{~K}, \mathrm{CD}_{2} \mathrm{Cl}_{2}\right): \delta-4.2--14.6$ (m). ${ }^{13} \mathrm{C}\left\{{ }^{1} \mathrm{H}\right\}$ NMR $\left(101 \mathrm{MHz}, 298 \mathrm{~K}, \mathrm{C}_{6} \mathrm{D}_{6}\right): \delta$ 161.4-160.8 (m, Ar-C), 136.6-135.9 (m, Ar-C), 115.0114.2 (Ar-C), 114.1-113.9 (m, Ar-C), 55.8-55.6 (m, O-Me). HRMS: 691.1238 m/z [M+H] $]^{+}$(calculated: 691.1245). Melting point: $192-194^{\circ} \mathrm{C}\left(\right.$ Lit. 188-192 $\left.{ }^{\circ} \mathrm{C}\right) .{ }^{21}$ IR (ATR, $\left.298 \mathrm{~K}\right): 3001$ (vw), $2936(\mathrm{w}), 2833$ (w), 2046 (vw), 1588 (vs), 1564 (s), 1492 (vs), 1457 (s), 1439 (s), 1401 (w), 1281 (s), 1242 (vs), 1174 (vs), 1106 (w), 1085 (s), 1024 (vs), 818 (vs), 794 (vs), 752 (s), 713 (w) cm-1.

${ }^{1} \mathrm{H}$ NMR $\left(500 \mathrm{MHz}, 298 \mathrm{~K}, \mathrm{CD}_{2} \mathrm{Cl}_{2}\right)$ :
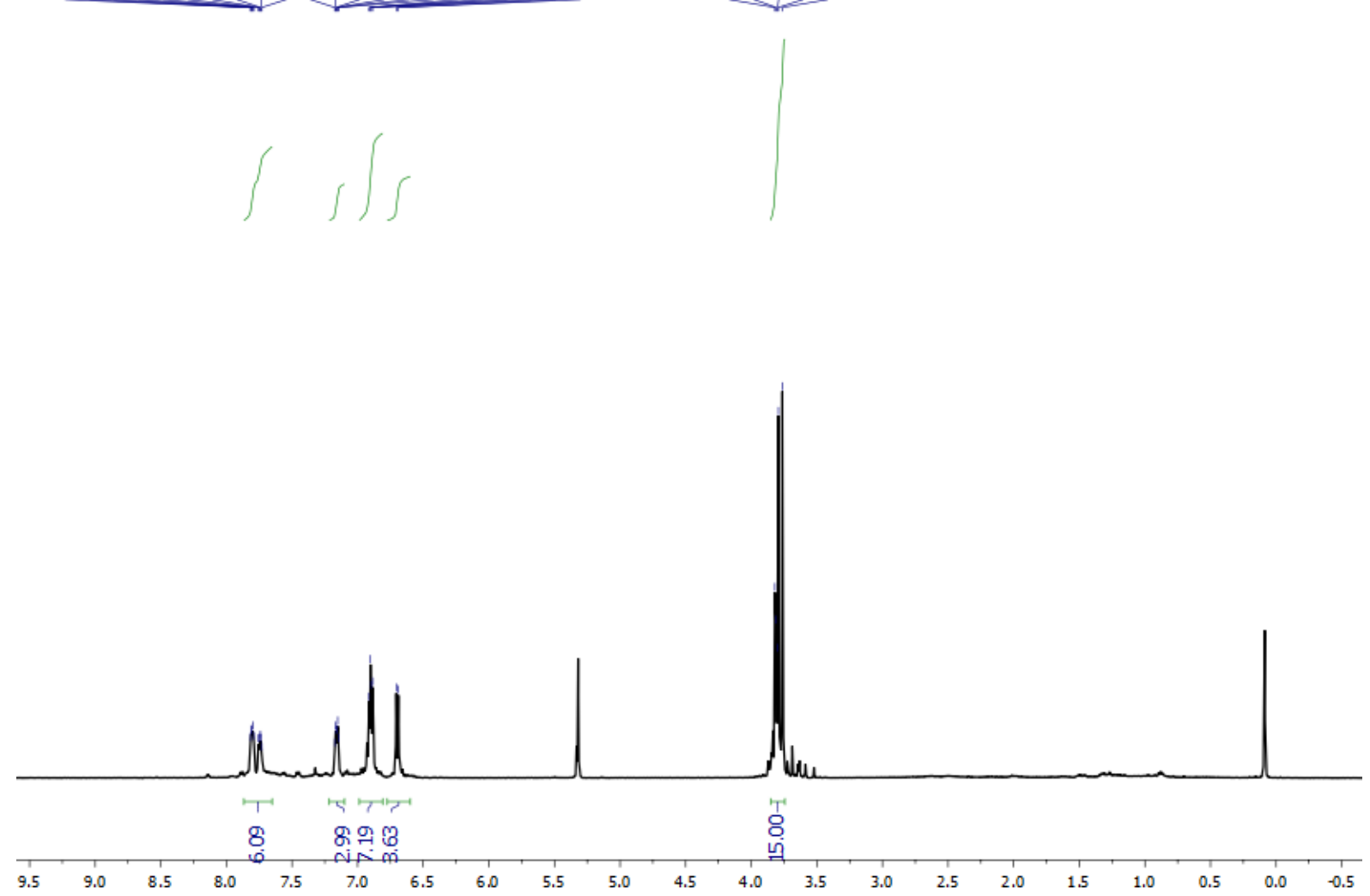
${ }^{31} \mathrm{P}$ NMR (162 MHz, $\left.298 \mathrm{~K}, \mathrm{CD}_{2} \mathrm{Cl}_{2}\right)$ :

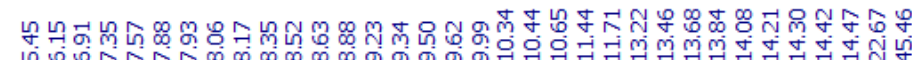

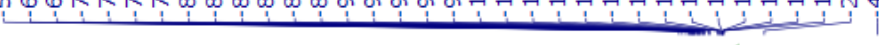

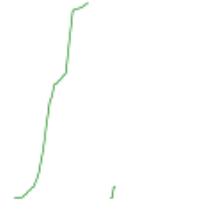

- $(\mathrm{PR})_{6}$

- $(\mathrm{PR})_{4}$

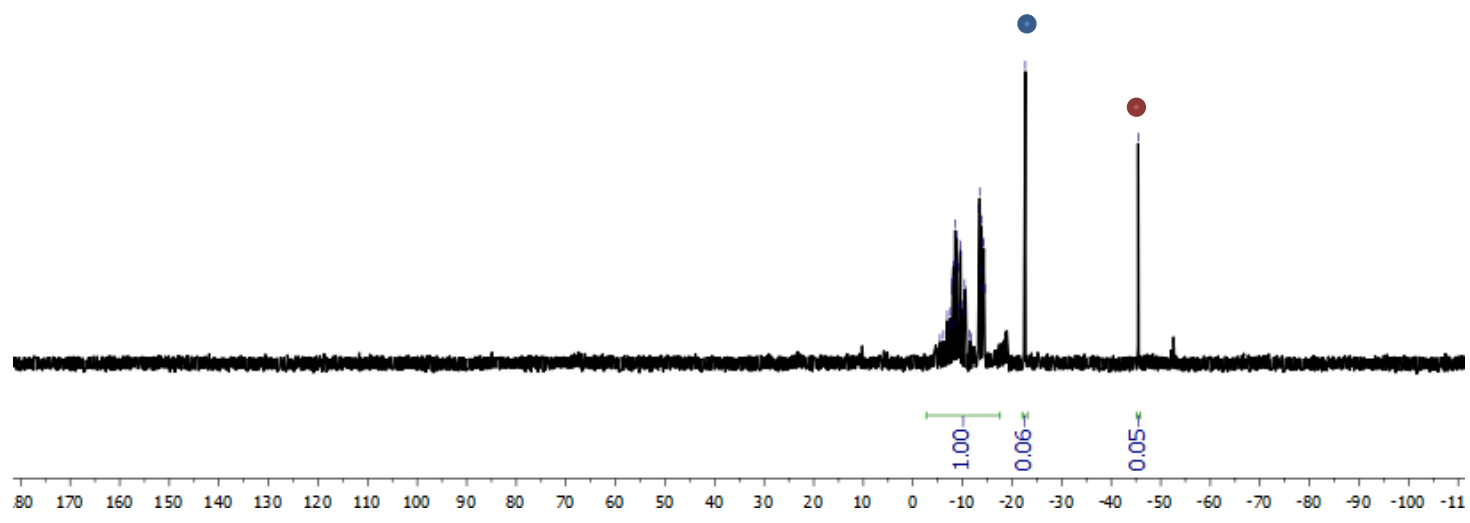

${ }^{13} \mathrm{C}\left\{{ }^{1} \mathrm{H}\right\}$ NMR $\left(101 \mathrm{MHz}, 298 \mathrm{~K}, \mathrm{CD}_{2} \mathrm{Cl}_{2}\right)$ :

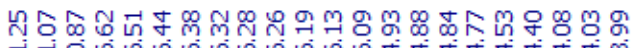

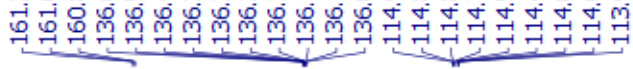

๓ֻ口ำ

织迤造出

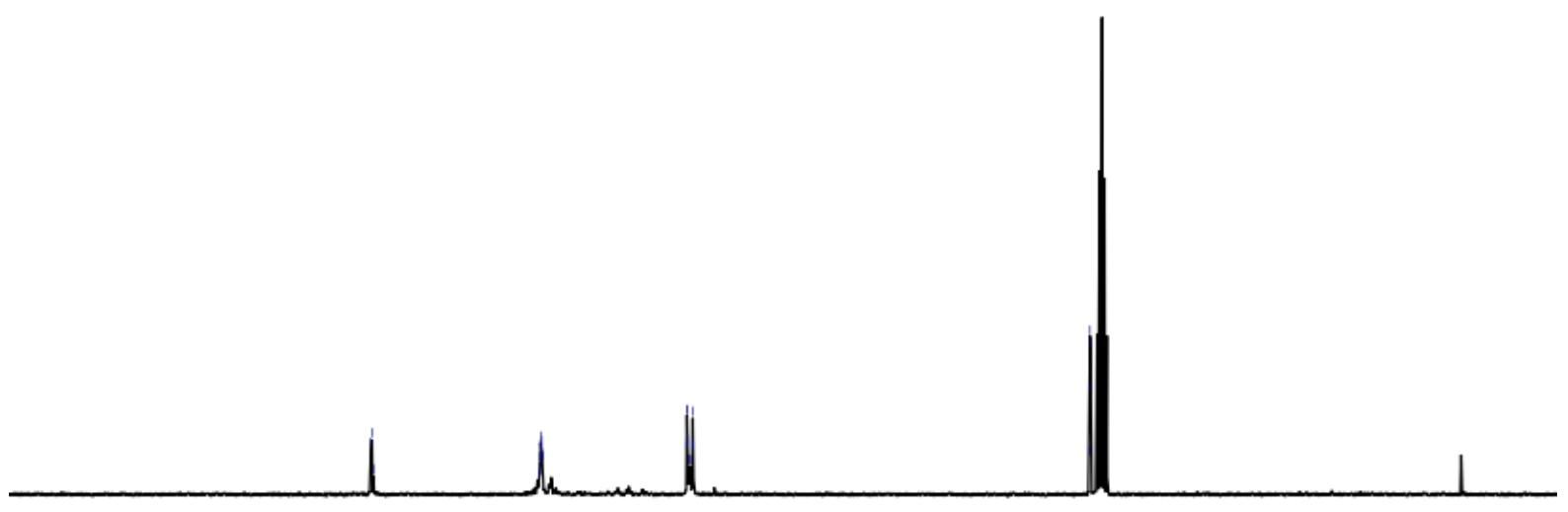

\begin{tabular}{llllllllllllllllllllllllllll}
\hline & 1 & 200 & 190 & 180 & 170 & 160 & 150 & 140 & 130 & 120 & 110 & 100 & 90 & 80 & 70 & 60 & 50 & 40 & 30 & 20 & 10 & 0 & -10
\end{tabular} 
1d:<smiles>FC(F)(F)c1ccc(-p2p(-c3ccc(C(F)(F)F)cc3)p(-c3ccc(C(F)(F)F)cc3)p(-c3ccc(C(F)(F)F)cc3)p2-c2ccc(C(F)(F)F)cc2)cc1</smiles>

Isolated as a white solid in $88 \%$ total yield as $83.9 \% \mathrm{P}_{5} \mathrm{R}_{5}, 0.4 \% \mathrm{P}_{6} \mathrm{R}_{6}, 3.7 \% \mathrm{P}_{4} \mathrm{R}_{4} .{ }^{1} \mathrm{H}$ NMR $(500 \mathrm{MHz}$, $\left.298 \mathrm{~K}, \mathrm{C}_{6} \mathrm{D}_{6}\right): \delta$ 7.82-7.40 (m, 6H, Ar- $H$ ), 7.35-7.18 (m, 6H, Ar- $H$ ), 7.15-7.04 (m, 4H, Ar- $H$ ), 7.04-6.86 $(\mathrm{m}, 4 \mathrm{H}, \mathrm{Ar}-\mathrm{H}) .{ }^{31} \mathrm{P}$ NMR $\left(162 \mathrm{MHz}, 298 \mathrm{~K}, \mathrm{C}_{6} \mathrm{D}_{6}\right): \delta 17.1(\mathrm{t}, \mathrm{J}=256.3 \mathrm{~Hz}), 10.6-4.2(\mathrm{~m}) .{ }^{1{ }^{3} \mathrm{C}}\left\{{ }^{1} \mathrm{H}\right\} \mathrm{NMR}$ $\left(101 \mathrm{MHz}, 298 \mathrm{~K}, \mathrm{C}_{6} \mathrm{D}_{6}\right): \delta$ 138.5, 136.8, 134.4-132.8 (m), 132.6-130.5 (m), 126.4-124.6 (m), 123.3, 121.2. ${ }^{19} \mathrm{~F}$ NMR $\left(470 \mathrm{MHz}, 298 \mathrm{~K}, \mathrm{C}_{6} \mathrm{D}_{6}\right): \delta-62.7$ - $-63.0(\mathrm{~m})$. HRMS: $881.0070 \mathrm{~m} / \mathrm{z}[\mathrm{M}+\mathrm{H}]^{+}$ (calculated: 881.0086). Melting Point: 108-111 ${ }^{\circ} \mathrm{C}$. IR: (ATR, $\left.298 \mathrm{~K}\right): 2924$ (w), 2855 (w), 1912 (vw), 1605 (s), 1568 (vw), 1395 (s), 1317 (vs), 1276 (w), 1262 (w), 1164 (s), 1118 (vs), 1105 (vs), 1087 (vs), 1057 (vs), 1013 (vs), 952 (w), 822 (vs), 729 (w), 695 (s) cm-1.

${ }^{1} \mathrm{H}$ NMR $\left(500 \mathrm{MHz}, 298 \mathrm{~K}, \mathrm{C}_{6} \mathrm{D}_{6}\right)$ :

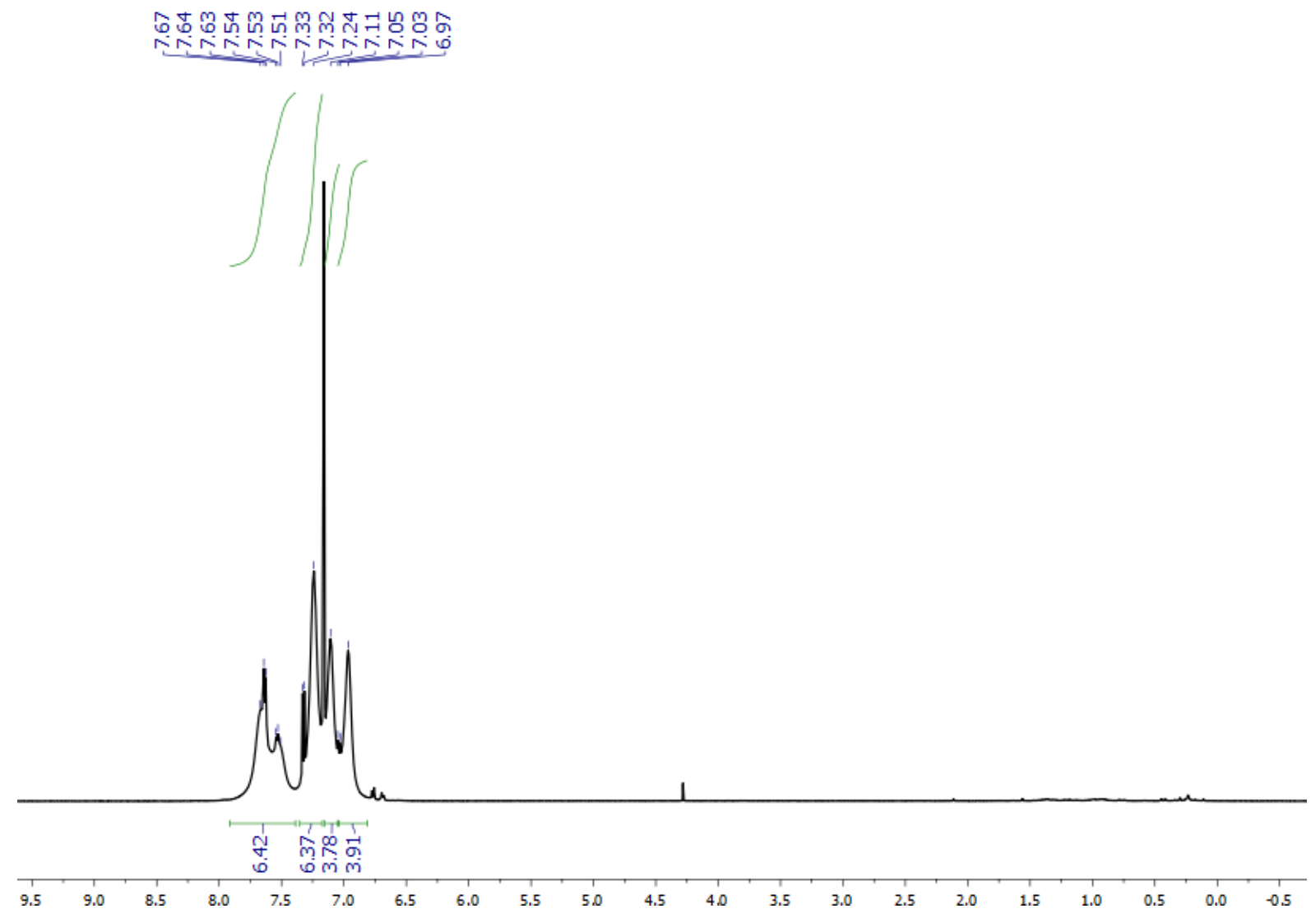


${ }^{31} \mathrm{P}$ NMR $\left(162 \mathrm{MHz}, 298 \mathrm{~K}, \mathrm{C}_{6} \mathrm{D}_{6}\right)$ :

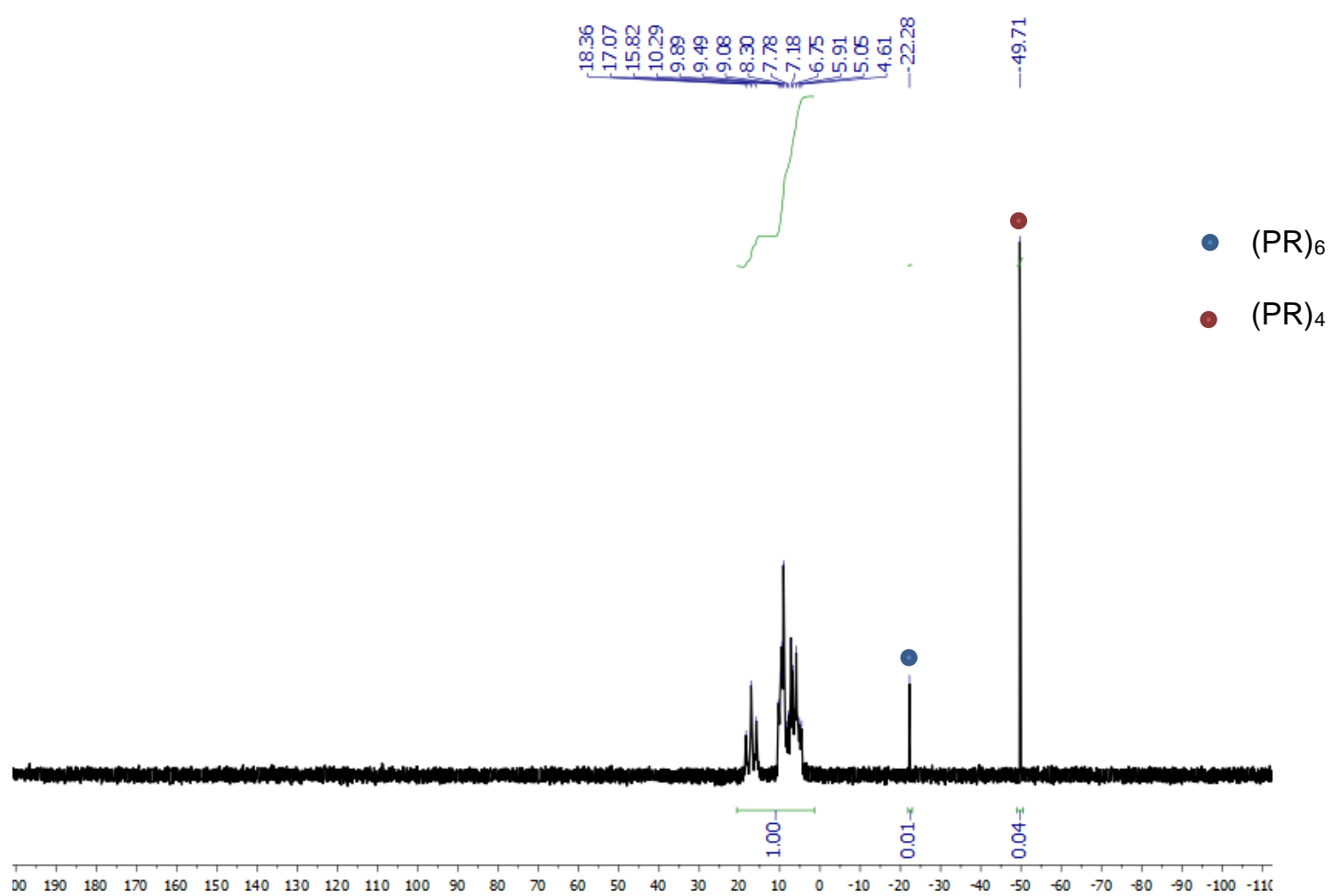

${ }^{13} \mathrm{C}\left\{{ }^{1} \mathrm{H}\right\}$ NMR (101 MHz, $\left.298 \mathrm{~K}, \mathrm{C}_{6} \mathrm{D}_{6}\right)$ :

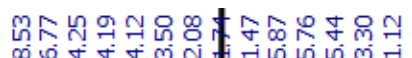

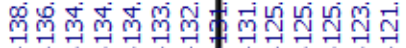

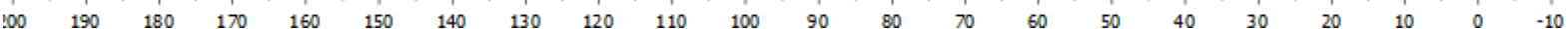


${ }^{19}$ F NMR $\left(470 \mathrm{MHz}, 298 \mathrm{~K}, \mathrm{C}_{6} \mathrm{D}_{6}\right)$ :

mo

บิ่

每

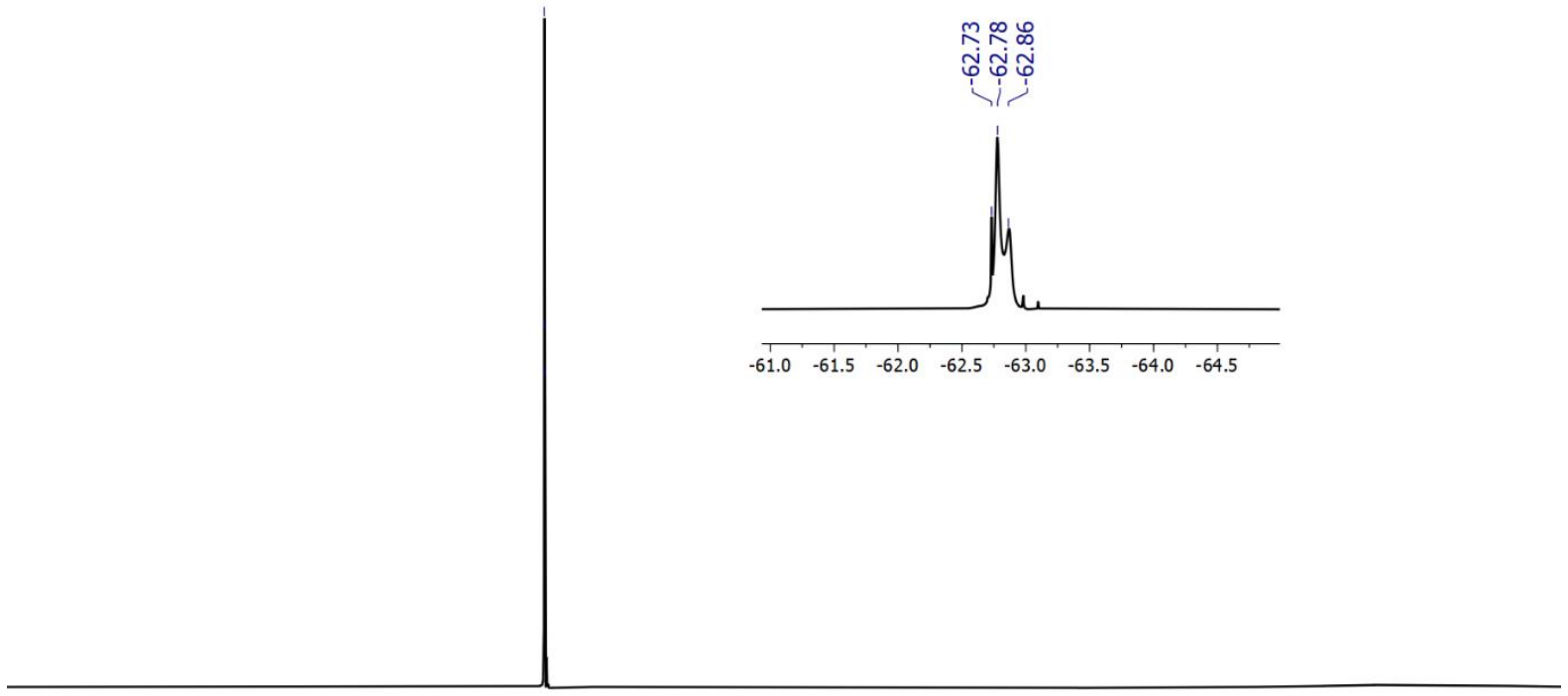

\begin{tabular}{lllllllllllllllllllllllllllllll}
\hline 0 & 10 & 0 & -10 & -20 & -30 & -40 & -50 & -60 & -70 & -80 & -90 & -100 & -110 & -120 & -130 & -140 & -150 & -160 & -170 & -180 & -190 & -200 & -210 & -22 \\
\hline
\end{tabular} 
1e:<smiles>Fc1ccc(-p2p(-c3ccc(F)cc3)p(-c3ccc(F)cc3)p(-c3ccc(F)cc3)p2-c2ccc(F)cc2)cc1</smiles>

Isolated as a white solid in $85 \%$ total yield as $75.9 \% \mathrm{P}_{5} \mathrm{R}_{5}, 5.8 \% \mathrm{P}_{6} \mathrm{R}_{6}, 3.3 \% \mathrm{P}_{4} \mathrm{R}_{4} .{ }^{1} \mathrm{H}$ NMR $(500 \mathrm{MHz}$, $\left.298 \mathrm{~K}, \mathrm{CD}_{2} \mathrm{Cl}_{2}\right): \delta$ 7.95-7.73 (m, 6H, Ar- $\left.H\right), 7.29-7.14(\mathrm{~m}, 4 \mathrm{H}, \mathrm{Ar}-\mathrm{H}), 7.09(\mathrm{t}, 6 \mathrm{H}, \mathrm{J}=8.5 \mathrm{~Hz}, \mathrm{Ar}-\mathrm{H}), 6.70$ $(\mathrm{t}, 4 \mathrm{H}, \mathrm{J}=8.5 \mathrm{~Hz}, \mathrm{Ar}-\mathrm{H}), 3.85-3.75(\mathrm{~m}, 3 \mathrm{H}, \mathrm{O}-\mathrm{Me}) .{ }^{31} \mathrm{P}$ NMR $\left(162 \mathrm{MHz}, 298 \mathrm{~K}, \mathrm{CD}_{2} \mathrm{Cl}_{2}\right): \delta-4.1--12.1$ (m). ${ }^{13} \mathrm{C}\left\{{ }^{1} \mathrm{H}\right\}$ NMR $\left(101 \mathrm{MHz}, 298 \mathrm{~K}, \mathrm{C}_{6} \mathrm{D}_{6}\right): 164.2\left(\mathrm{~d},{ }^{1} \mathrm{~J}_{\mathrm{C}-\mathrm{F}}=249.5 \mathrm{~Hz}, \mathrm{Ar}-\mathrm{C}-\mathrm{F}\right), 137.0-136.0(\mathrm{~m}, \mathrm{Ar}-\mathrm{C})$, 135.3-134.7 (m, Ar-C) 116.8-115.6 (m, Ar-C). HRMS: $631.0233 \mathrm{~m} / \mathrm{z}[\mathrm{M}+\mathrm{H}]^{+}$(calculated: 631.0246). Melting Point: 201-204 ${ }^{\circ} \mathrm{C}$. IR (ATR, 298 K): 3057 (vw), 2964 (vw), 1887 (vw), 1584 (s), 1488 (vs), 1391 (w), 1298 (w), 1261 (vw), 1226 (vs), 1157 (vs), 1093 (s), 1080 (s), 1012 (s), 935 (w), 818 (vs), 756 (w), $704(w) \mathrm{cm}^{-1}$.

${ }^{1} \mathrm{H}$ NMR $\left(500 \mathrm{MHz}, 298 \mathrm{~K}, \mathrm{CD}_{2} \mathrm{Cl}_{2}\right)$ :

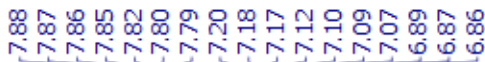
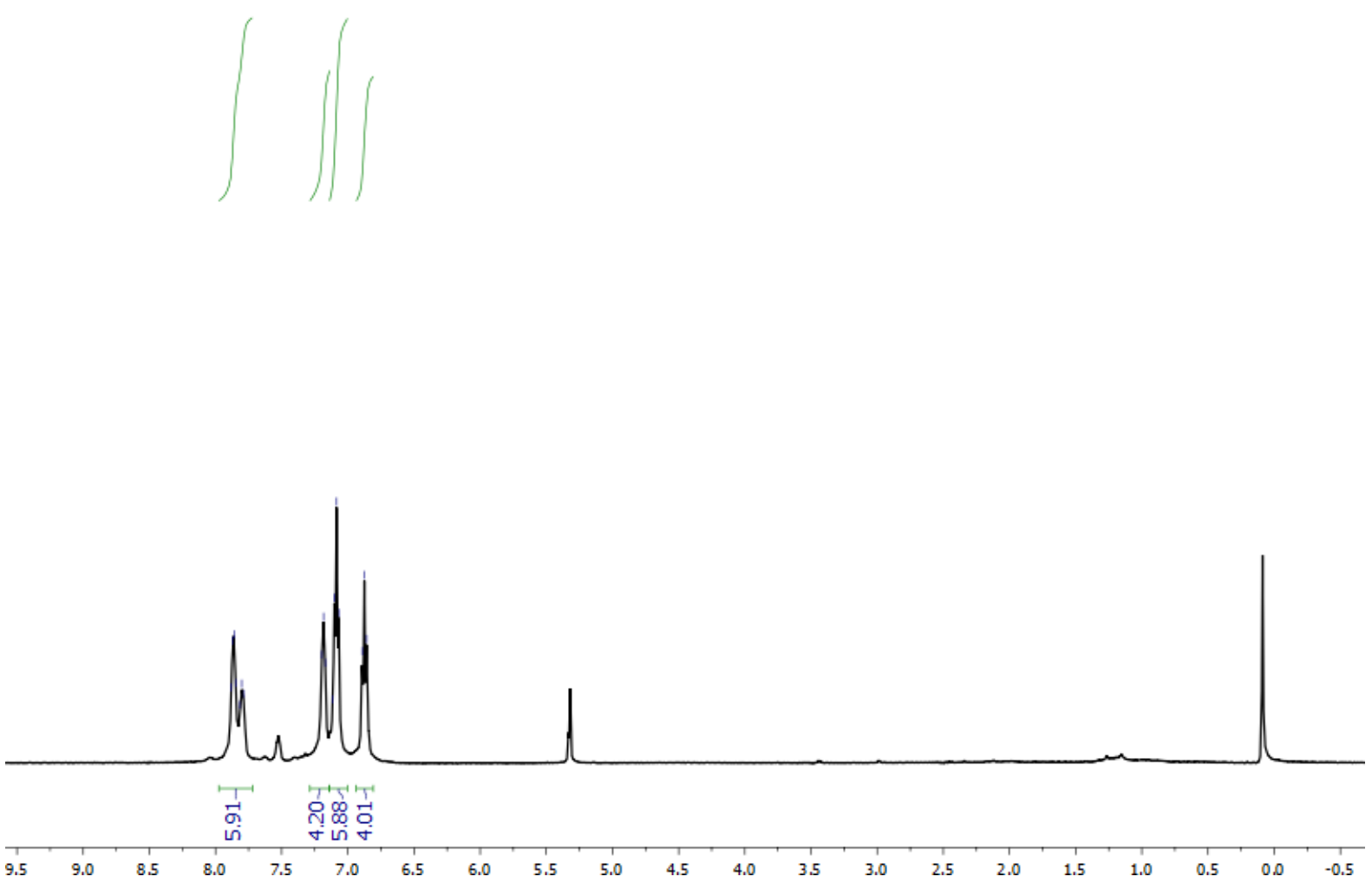
${ }^{31} \mathrm{P}$ NMR $\left(162 \mathrm{MHz}, 298 \mathrm{~K}, \mathrm{CD}_{2} \mathrm{Cl}_{2}\right)$ :

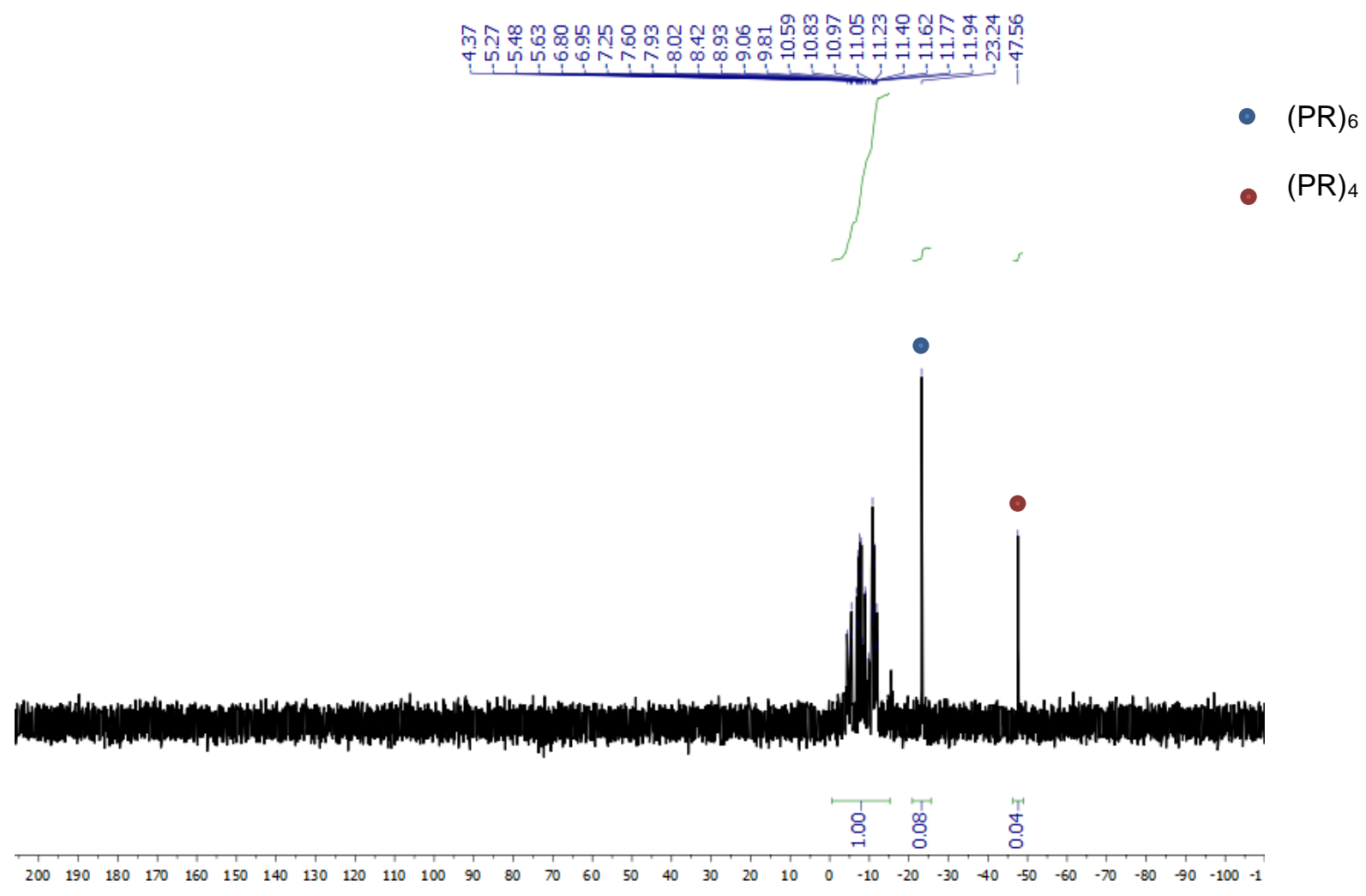

${ }^{13} \mathrm{C}\left\{{ }^{1} \mathrm{H}\right\}$ NMR $\left(101 \mathrm{MHz}, 298 \mathrm{~K}, \mathrm{CD}_{2} \mathrm{Cl}_{2}\right)$ :

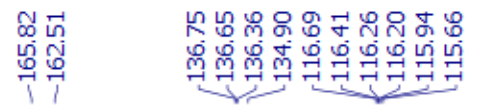

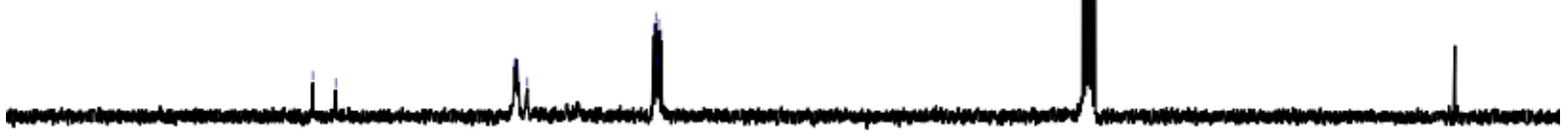

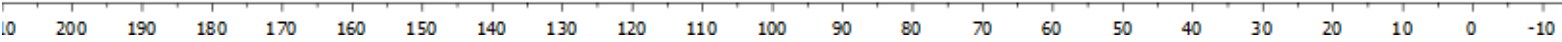


1f:<smiles>c1cpc2c(c1)P(c1cccc3ccccc13)P(c1cccc3ccccc13)P(c1cccc3ccccc13)P(c1cccc3ccccc13)P2c1cccc2ccccc12</smiles>

Not Isolated. Product obtained as a mixture of 5- and 4- membered rings along with 1napthylphosphine in $77 \mathrm{mg}$ yield. Product ratio by ${ }^{31} \mathrm{P}$ NMR: $\mathrm{P}_{5}$ (1-naphthyl) 5 59\%, $\mathrm{P}_{4}$ (1-naphthyl) 4 29\%, 1-naphthylphosphine $11 \%$.

${ }^{31}$ P NMR (162 MHz, $\left.298 \mathrm{~K}, \mathrm{C}_{6} \mathrm{D}_{6}\right)$ :
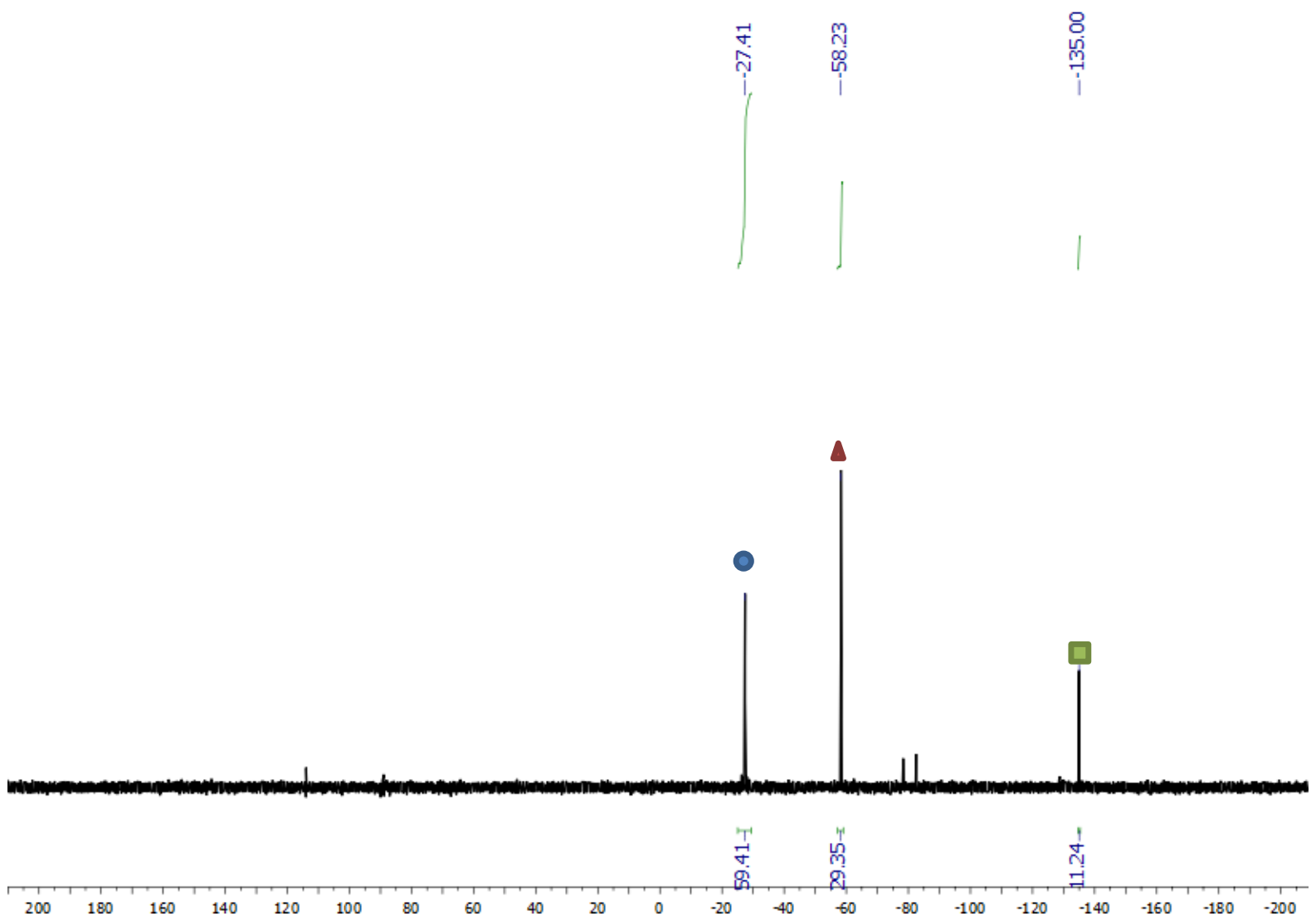

- $(\mathrm{P}(1 \text {-naphthyl }))_{5} \quad \Delta(\mathrm{P}(1 \text {-naphthyl }))_{4} \quad \square \quad$ 1-naphthylphosphine 
1g:<smiles>c1ccc2cc(-p3p(-c4ccc5ccccc5c4)p(-c4ccc5ccccc5c4)p(-c4ccc5ccccc5c4)p3-c3ccc4ccccc4c3)ccc2c1</smiles>

Isolated as a pale yellow solid in $95 \%$ total yield as $87.9 \% \mathrm{P}_{5} \mathrm{R}_{5}, 0.7 \% \mathrm{P}_{6} \mathrm{R}_{6}, 6.4 \% \mathrm{P}_{4} \mathrm{R}_{4} .{ }^{1} \mathrm{H}$ NMR $(500$ $\left.\mathrm{MHz}, 298 \mathrm{~K}, \mathrm{C}_{6} \mathrm{D}_{6}\right): \delta 8.68(\mathrm{~s}(b r), 2 \mathrm{H}), 8.36(\mathrm{~d}, 2 \mathrm{H}, \mathrm{J}=8.2 \mathrm{~Hz}), 8.20-8.13(\mathrm{~m}, 1 \mathrm{H}), 7.98(\mathrm{~s}(b r), 2 \mathrm{H})$, 7.63-7.51 (m, 4H), 7.51-7.38 (m, 7H), $7.35(\mathrm{~d}, 2 \mathrm{H}, \mathrm{J}=8.2 \mathrm{~Hz}), 7.25-6.92(\mathrm{~m}, 15 \mathrm{H}) .{ }^{31} \mathrm{P}$ NMR $(162$ $\left.\mathrm{MHz}, 298 \mathrm{~K}, \mathrm{C}_{6} \mathrm{D}_{6}\right): \delta 2.5--3.05(\mathrm{~m}) .{ }^{13} \mathrm{C}\left\{{ }^{1} \mathrm{H}\right\} \mathrm{NMR}\left(101 \mathrm{MHz}, 298 \mathrm{~K}, \mathrm{C}_{6} \mathrm{D}_{6}\right): \delta 134.6-134.1(\mathrm{~m}), 133.8-$ $132.9(\mathrm{~m}), 132.4-131.9(\mathrm{~m}), 130.9-139.6(\mathrm{~m}), 128.5,128.1,126.7-126.0(\mathrm{~m})$. HRMS: $813.1313 \mathrm{~m} / \mathrm{z}$ [M+Na] ${ }^{+}$(calculated: 813.1319). Melting Point: 257-259 C. IR (ATR, 298 K): 3049 (w), 2919 (w), 2856 (w), $2291(\mathrm{vw}), 1912(\mathrm{vw}), 1762(\mathrm{vw}), 1705(\mathrm{vw}), 1623(\mathrm{w}), 1585(\mathrm{~s}), 1497(\mathrm{~s}), 1456(\mathrm{w}), 1427(\mathrm{w}), 1351$ (w), $1332(\mathrm{w}), 1269(\mathrm{w}), 1239(\mathrm{vw}), 1196(\mathrm{vw}), 1160(\mathrm{w}), 1133(\mathrm{~s}), 1071(\mathrm{~s}), 1015(\mathrm{w}), 852(\mathrm{~s}), 808(\mathrm{vs})$, 765 (w), 729 (vs), 694 (s) $\mathrm{cm}^{-1}$.

${ }^{1} \mathrm{H}$ NMR $\left(500 \mathrm{MHz}, 298 \mathrm{~K}, \mathrm{C}_{6} \mathrm{D}_{6}\right)$ :

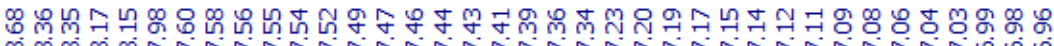

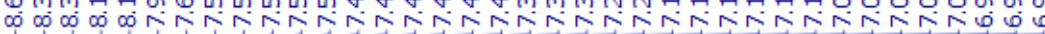
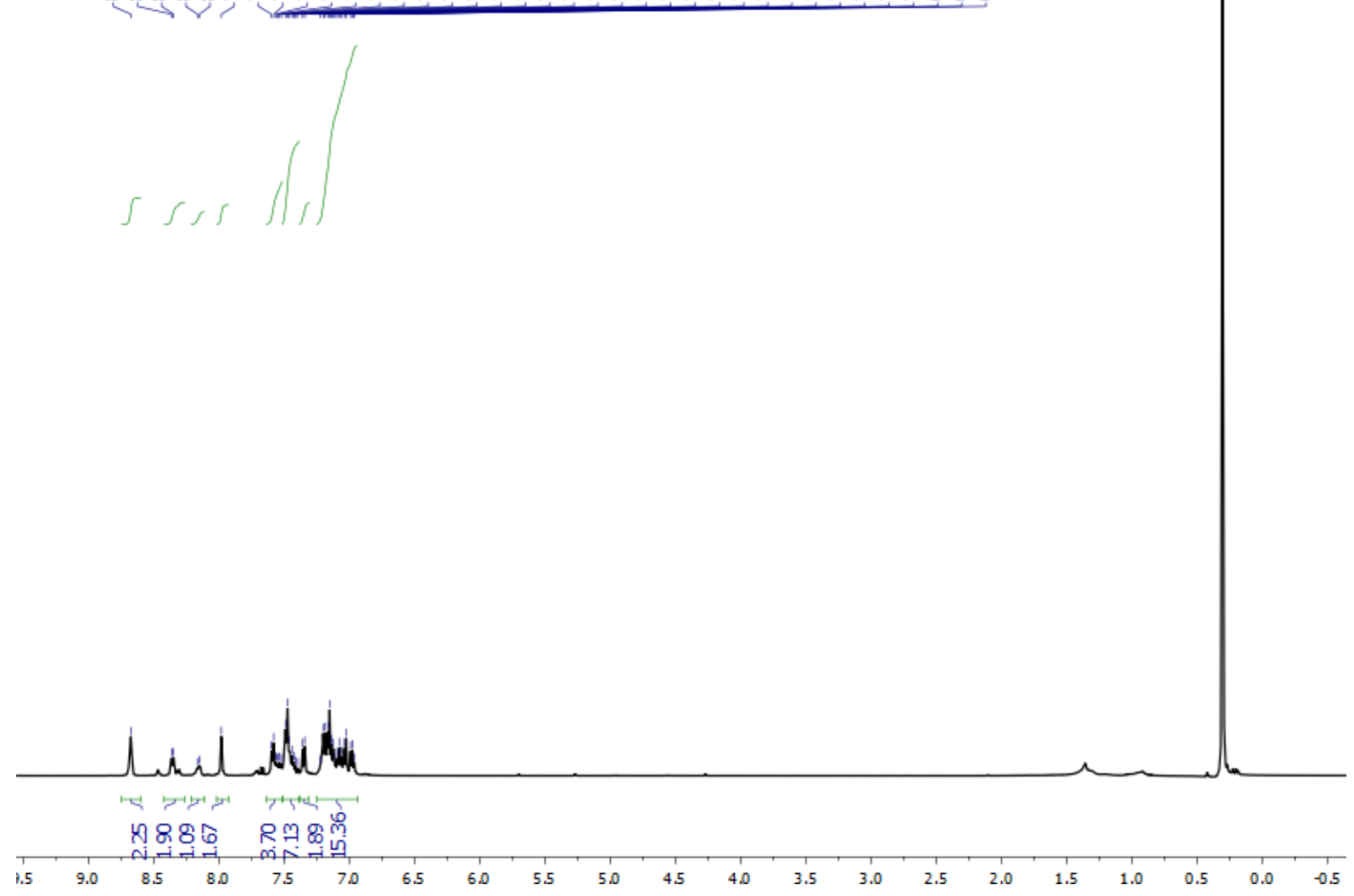
${ }^{31} \mathbf{P}$ NMR (162 MHz, $\left.298 \mathrm{~K}, \mathrm{C}_{6} \mathrm{D}_{6}\right)$ :

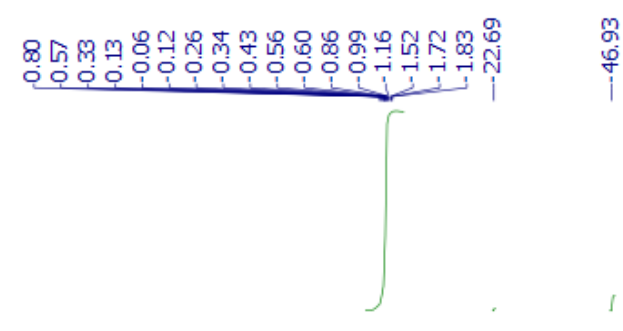

- $(\mathrm{PR})_{6}$

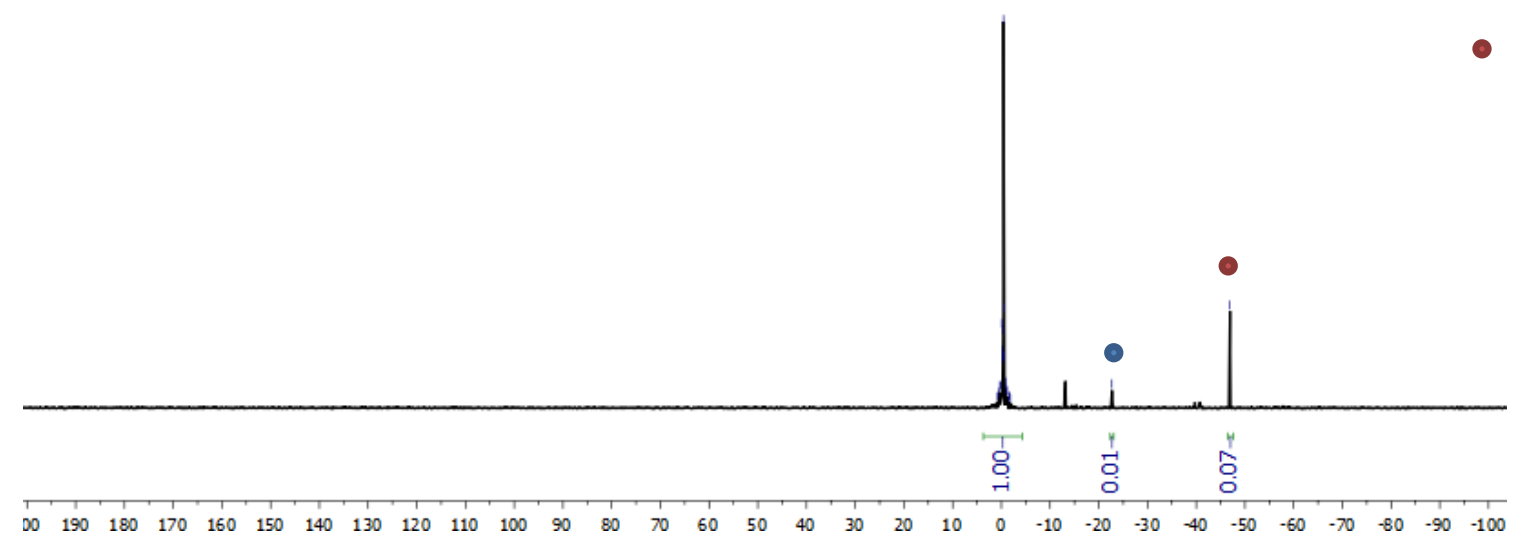

- $(\mathrm{PR})_{4}$

${ }^{13} \mathrm{C}\left\{{ }^{1} \mathrm{H}\right\}$ NMR $\left(101 \mathrm{MHz}, 298 \mathrm{~K}, \mathrm{C}_{6} \mathrm{D}_{6}\right):$

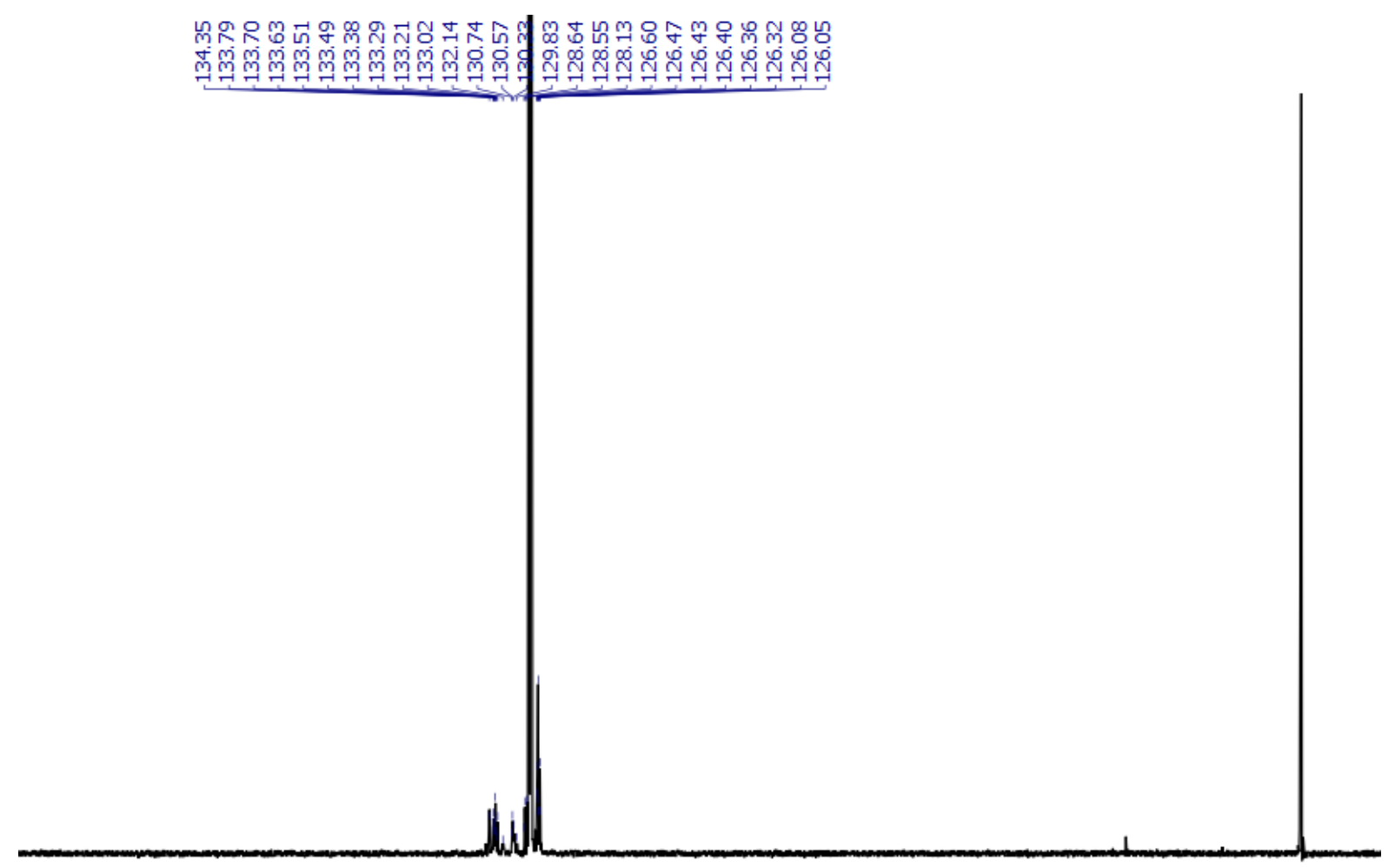


1h:<smiles></smiles>

Isolated as a yellow solid in $63 \%$ yield. ${ }^{31} \mathrm{P}\left\{{ }^{1} \mathrm{H}\right\}$ solid-state NMR $(298 \mathrm{~K}): \delta 23.4--39.0(\mathrm{br}) .{ }^{13} \mathrm{C}\left\{{ }^{1} \mathrm{H}\right\}$ solid-state NMR (298 K): $\delta$ 145.0-199.0 (br). HRMS: $1041.2262 \mathrm{~m} / \mathrm{z}[\mathrm{M}+\mathrm{H}]^{+}$(calculated: 1041.2282). Melting point: $>300^{\circ} \mathrm{C}$. IR (ATR, $\left.298 \mathrm{~K}\right)$ : 3053 (w), 2963 (w), 2271 (vw), $1611(\mathrm{vw}), 1571(\mathrm{vw}), 1489$ $(w), 1447(w), 1437(w), 1364(w), 1260(w), 1243(w), 1145(w), 1087(s), 1019(s), 941(w), 890(s)$, 798 (s), 734 (vs), 714 (vs) $\mathrm{cm}^{-1}$.

${ }^{31} \mathrm{P}\left\{{ }^{1} \mathrm{H}\right\}$ solid-state NMR $(298 \mathrm{~K})$ :

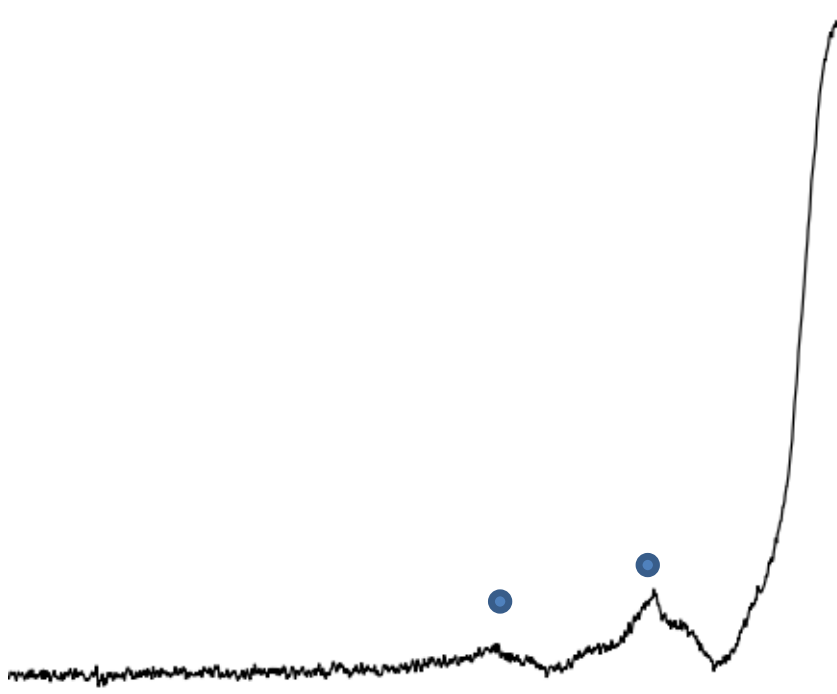


${ }^{13} \mathrm{C}\left\{{ }^{1} \mathrm{H}\right\}$ solid-state NMR $(298 \mathrm{~K})$ :

- Spinning side-bands

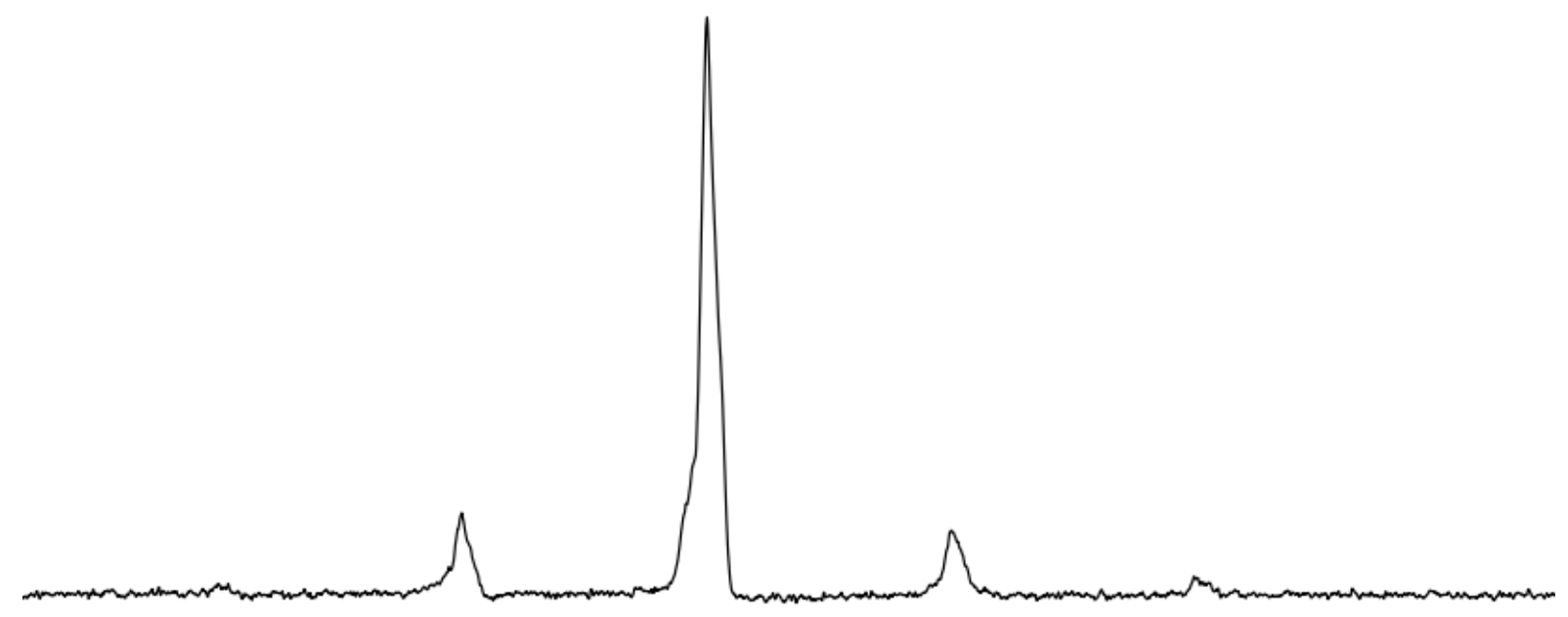

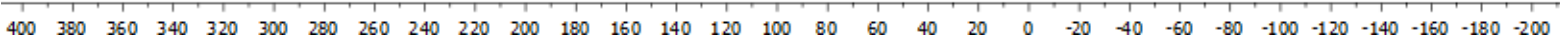


1i:

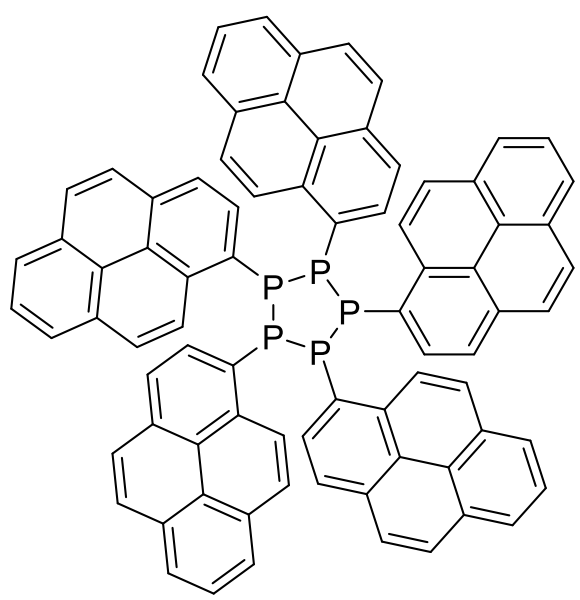

Isolated as a yellow solid in $78 \%$ yield. ${ }^{31} \mathrm{P}\left\{{ }^{1} \mathrm{H}\right\}$ solid-state NMR $(298 \mathrm{~K}): \delta 30--50(\mathrm{br}) .{ }^{13} \mathrm{C}\left\{{ }^{1} \mathrm{H}\right\}$ solidstate NMR (298 K): $\delta$ 142-118 (br). HRMS: $1183.2224 \mathrm{~m} / \mathrm{z}[\mathrm{M}+\mathrm{H}]^{+}$(calculated: 1183.2102). Melting point (decomposition): Yellow to red colour change $251-253^{\circ} \mathrm{C}$. IR (ATR, $\left.298 \mathrm{~K}\right)$ : 3036 (w), 2280 (vw), 1912 (vw), 1582 (w), 1482 (vw), 1456 (vw), 1413 (vw), 1383 (vw), 1243 (vw), 1202 (s), 1177 (w), 1153 (w), 1079 (w), 955 (s), 836 (vs), 817 (s), 750 (s), 710 (vs), 678 (w) cm-1.

${ }^{31} \mathrm{P}\left\{{ }^{1} \mathrm{H}\right\}$ solid-state NMR $(298 \mathrm{~K})$ : 


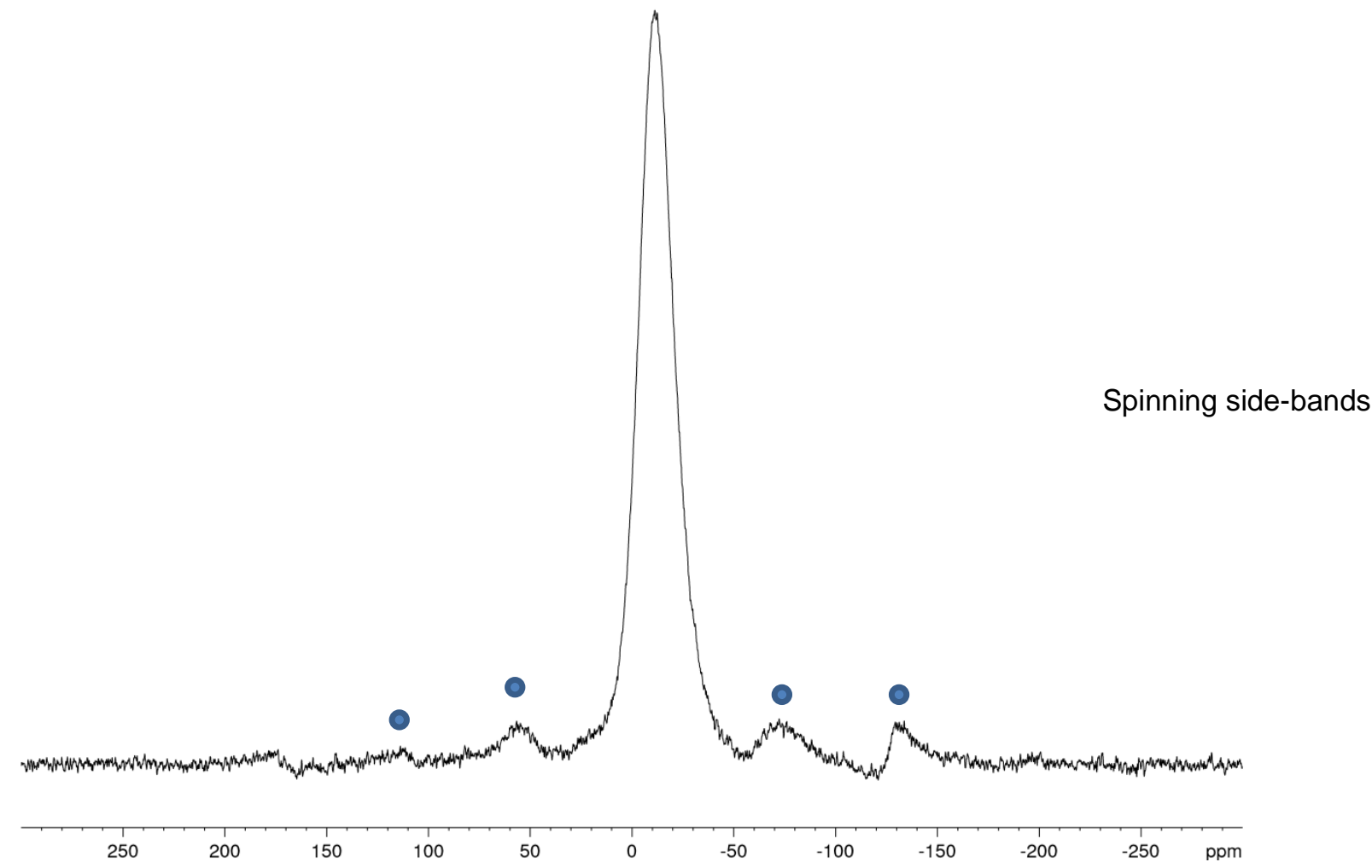

${ }^{13} \mathrm{C}\left\{{ }^{1} \mathrm{H}\right\}$ solid-state NMR (298 K):

- Spinning side-bands 


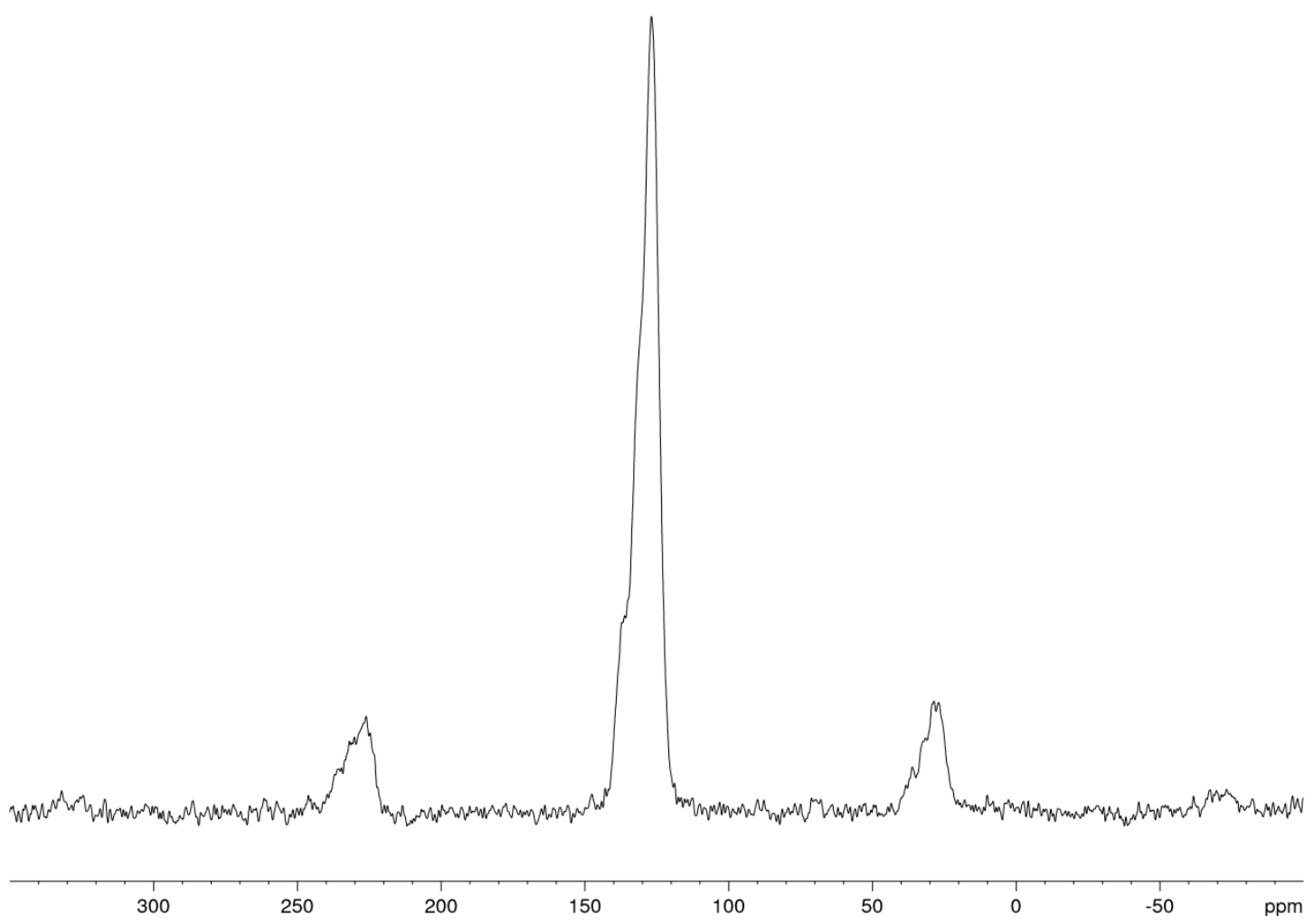

8. Spectroscopic Data Figure 2 2a: 
<smiles></smiles>

Isolated as a white solid in $72 \%$ yield. ${ }^{1} \mathbf{H}$ NMR $\left(500 \mathrm{MHz}, 298 \mathrm{~K}, \mathrm{CD}_{2} \mathrm{Cl}_{2}\right): \delta 1.94(\mathrm{~d}, 7 \mathrm{H}, \mathrm{J}=12.9 \mathrm{~Hz})$, 1.86-1.72 (m, 12H), 1.71-1.61 (m, 6H), 1.34-1.16 (m, 12H), 1.15-0.99 (m, 7H). ${ }^{31}$ P NMR (162 MHz, 298 $\left.\mathrm{K}, \mathrm{CD}_{2} \mathrm{Cl}_{2}\right): \delta-66.7(\mathrm{~s}) .{ }^{13} \mathrm{C}\left\{{ }^{1} \mathrm{H}\right\}$ NMR $\left(101 \mathrm{MHz}, 298 \mathrm{~K}, \mathrm{CD}_{2} \mathrm{Cl}_{2}\right): 39.3,30.2-29.9(\mathrm{~m}), 27.5,26.8$. The values are in accordance to the literature. ${ }^{19}$ HRMS: $457.2465 \mathrm{~m} / \mathrm{z}[\mathrm{M}+\mathrm{H}]^{+}$(calculated: 457.2466). Melting point: $224-225^{\circ} \mathrm{C}\left(\right.$ Lit. $\left.222-224^{\circ} \mathrm{C}\right) .{ }^{22}$

${ }^{1} \mathrm{H}$ NMR $\left(500 \mathrm{MHz}, 298 \mathrm{~K}, \mathrm{CD}_{2} \mathrm{Cl}_{2}\right)$ :

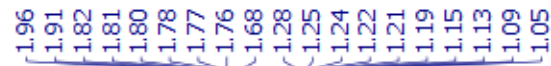
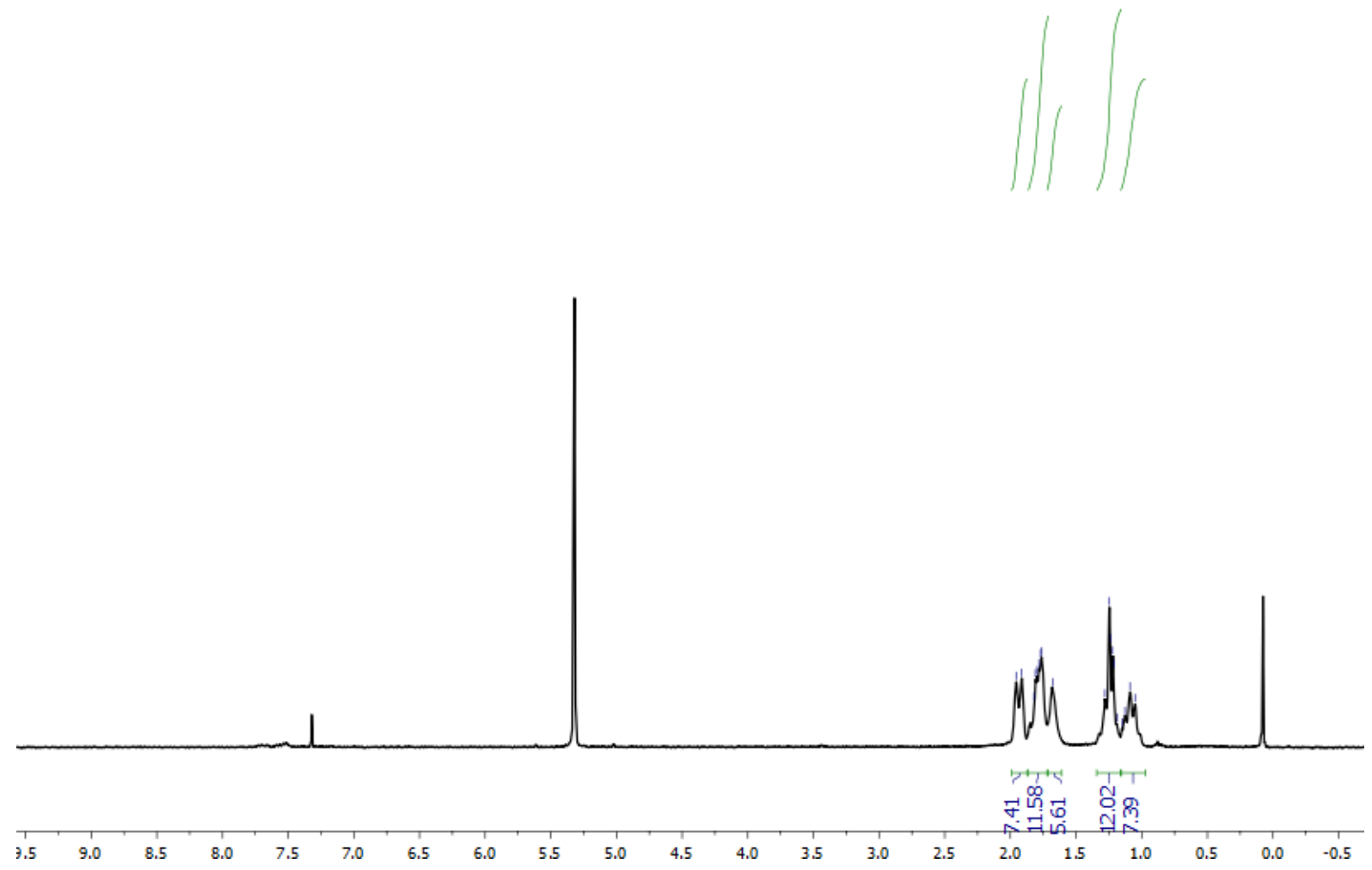

${ }^{31} \mathrm{P}$ NMR $\left(162 \mathrm{MHz}, 298 \mathrm{~K}, \mathrm{CD}_{2} \mathrm{Cl}_{2}\right)$ : 


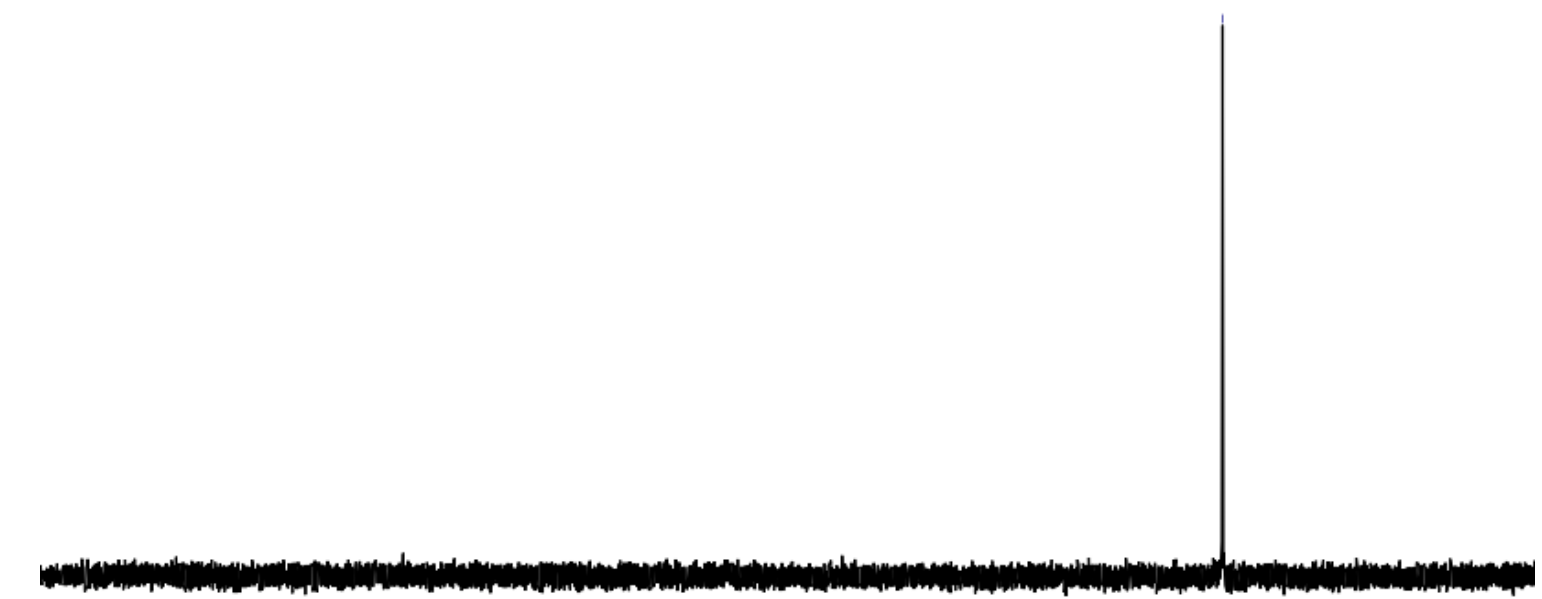

$\begin{array}{lllllllllllllllllllllllllllllll}140 & 130 & 120 & 110 & 100 & 90 & 80 & 70 & 60 & 50 & 40 & 30 & 20 & 10 & 0 & -10 & -20 & -30 & -40 & -50 & -60 & -70 & -80 & -90 & -100 & -110 & -120\end{array}$ ${ }^{13} \mathbf{C}\left\{{ }^{1} \mathrm{H}\right\}$ NMR $\left(101 \mathrm{MHz}, 298 \mathrm{~K}, \mathrm{CD}_{2} \mathrm{Cl}_{2}\right)$ :
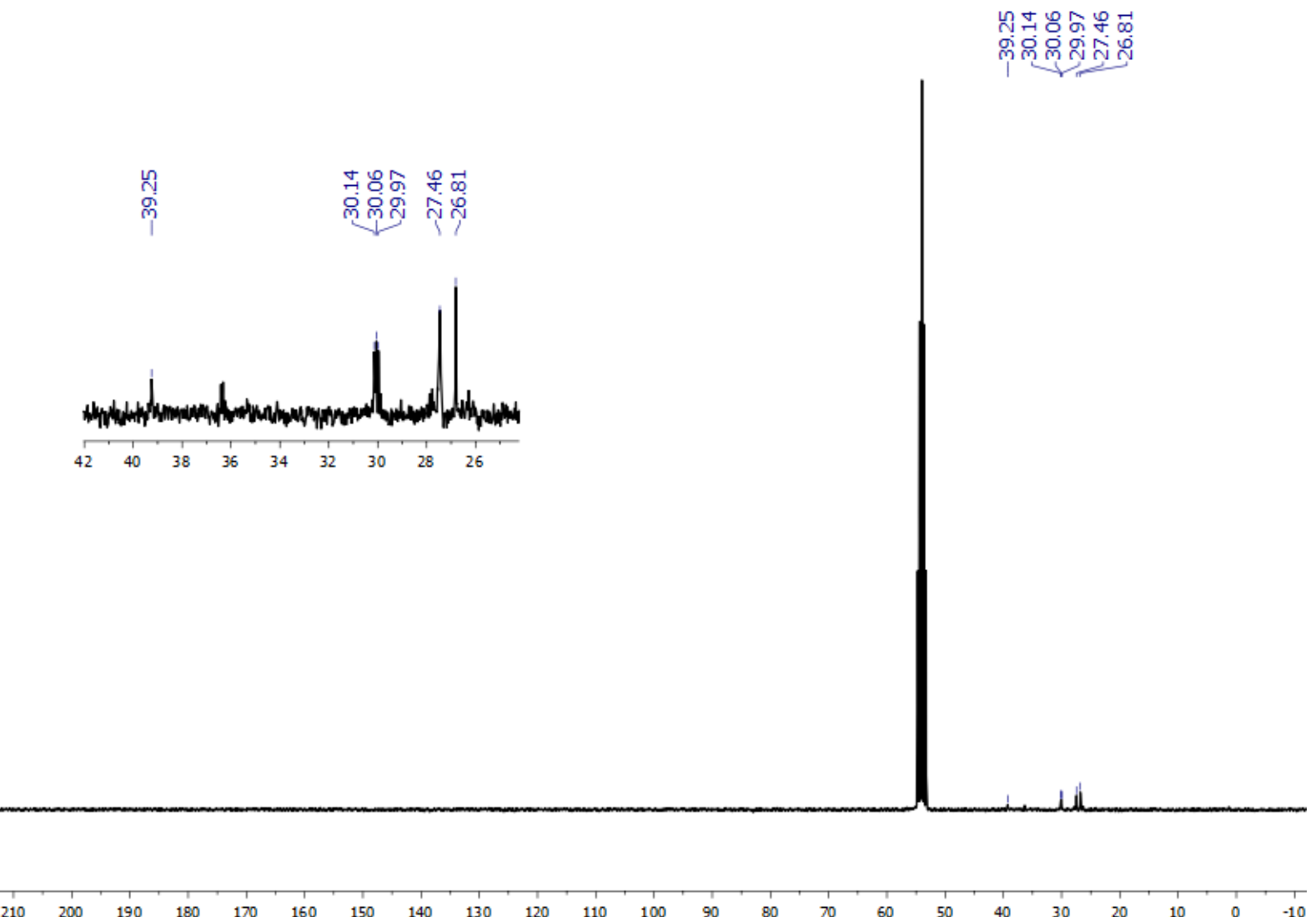

2b: 
<smiles>c1ccc(Cp2p(Cc3ccccc3)p(Cc3ccccc3)p(Cc3ccccc3)p2Cc2ccccc2)cc1</smiles>

Isolated as a colourless oil in $83 \%$ total yield as $78.8 \% \mathrm{P}_{5} \mathrm{R}_{5}, 0.0 \% \mathrm{P}_{6} \mathrm{R}_{6}, 4.2 \% \mathrm{P}_{4} \mathrm{R}_{4} .{ }^{1} \mathrm{H}$ NMR $(500 \mathrm{MHz}$, $\left.298 \mathrm{~K}, \mathrm{C}_{6} \mathrm{D}_{6}\right): \delta 7.23$ (d, 4H, J = 7.5 Hz, Ar-H), 7.20-7.17 (m, 4H, Ar-H), 7.15-7.05 (m, 12H, Ar-H), 7.02$6.94(\mathrm{~m}, 5 \mathrm{H}, \mathrm{Ar}-\mathrm{H})$ 3.27-3.10 (m, 4H, P-C $\left.\mathrm{Z}^{-}\right), 3.08-2.89\left(\mathrm{~m}, 6 \mathrm{H}, \mathrm{P}-\mathrm{CH}_{2^{-}}\right) .{ }^{31} \mathrm{P}$ NMR $(162 \mathrm{MHz}, 298 \mathrm{~K}$, $\left.\mathrm{C}_{6} \mathrm{D}_{6}\right): \delta$ 4.1-1.4 (m, 1P), -2.3 - -5.1 (m, 2P), -13.7 (ps-ddd, $\left.2 \mathrm{P}, \mathrm{J}=153.6 \mathrm{~Hz}, 83.9 \mathrm{~Hz}, 31.9 \mathrm{~Hz}\right) .{ }^{13} \mathrm{C}\left\{{ }^{1} \mathrm{H}\right\}$ NMR $\left(101 \mathrm{MHz}, 298 \mathrm{~K}, \mathrm{C}_{6} \mathrm{D}_{6}\right)$ : 139.8-139.5 (m, Ar-C), 129.7-129.4 (m, Ar-C), 128.9 (Ar-C), 128.7 (ArC), 128.6-128.5 (m, Ar-C), 126.7 (Ar-C), 126.5 (Ar-C), 126.4 (d, J = 2.3 Hz, Ar-C), 35.4-35.0 (m, P-CH ), 34.5-33.9 (m, P-CH $\left.2^{-}\right), 30.0-29.6\left(\mathrm{~m}, \mathrm{P}-\mathrm{CH}_{2}-\right)$. HRMS: $611.1482 \mathrm{~m} / \mathrm{z}[\mathrm{M}+\mathrm{H}]^{+}$(calculated: 611.1499$)$. IR: (ATR, $298 \mathrm{~K})$ : 3058 (w), 3025 (w), 2904 (vw), 1867 (vw), 1598 (s), 1581 (w), 1492 (vs), 1451 (s), $1412(w), 1264$ (vw), 1207 (w), 1181 (w), 1156 (vw), 1062 (w), 1028 (w), 907 (w), $812(w), 761$ (vs), 694 (vs) $\mathrm{cm}^{-1}$.

${ }^{1} \mathbf{H}$ NMR $\left(500 \mathrm{MHz}, 298 \mathrm{~K}, \mathrm{C}_{6} \mathrm{D}_{6}\right)$ :

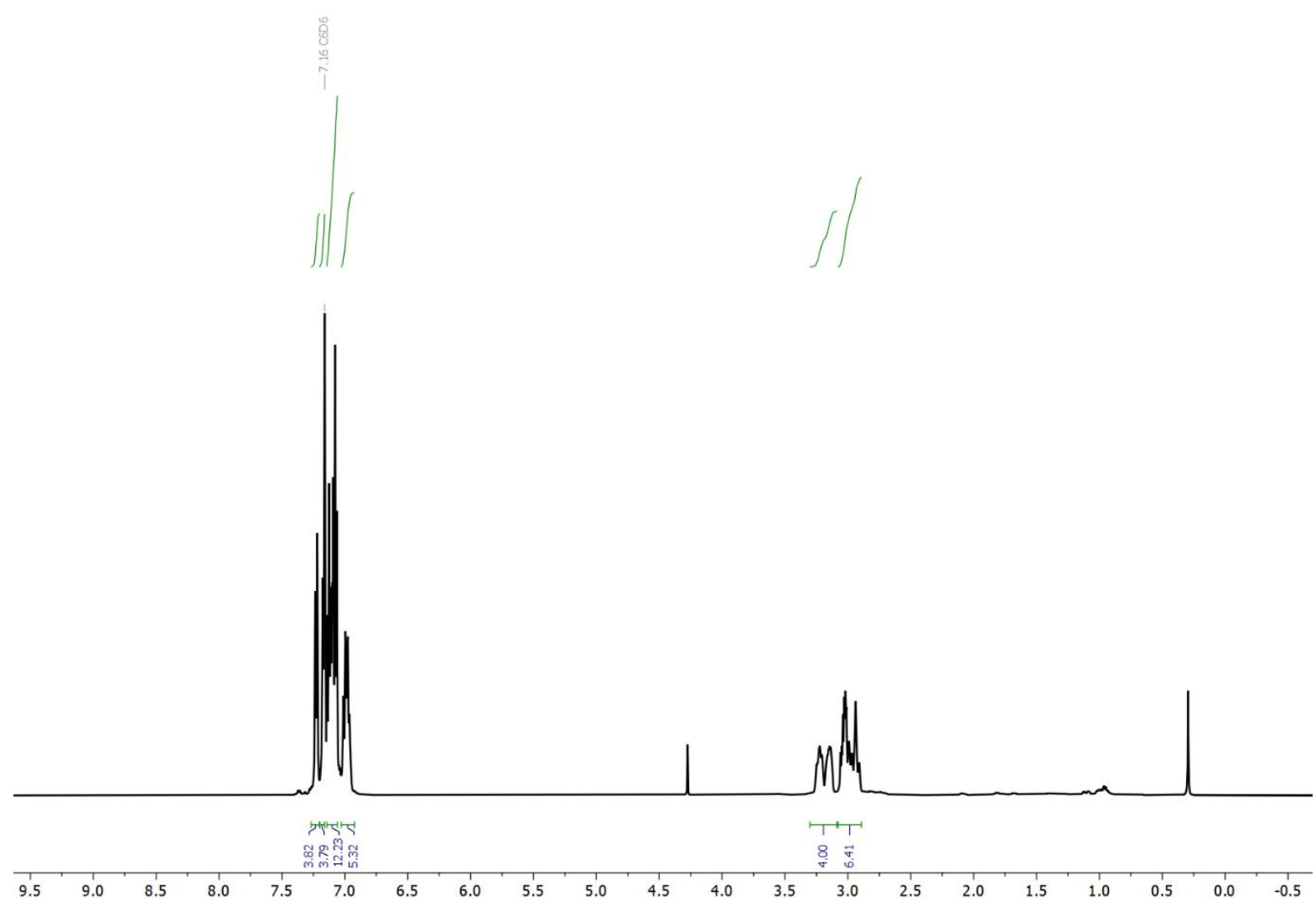

${ }^{31}$ P NMR (162 MHz, $\left.298 \mathrm{~K}, \mathrm{C}_{6} \mathrm{D}_{6}\right)$ : 


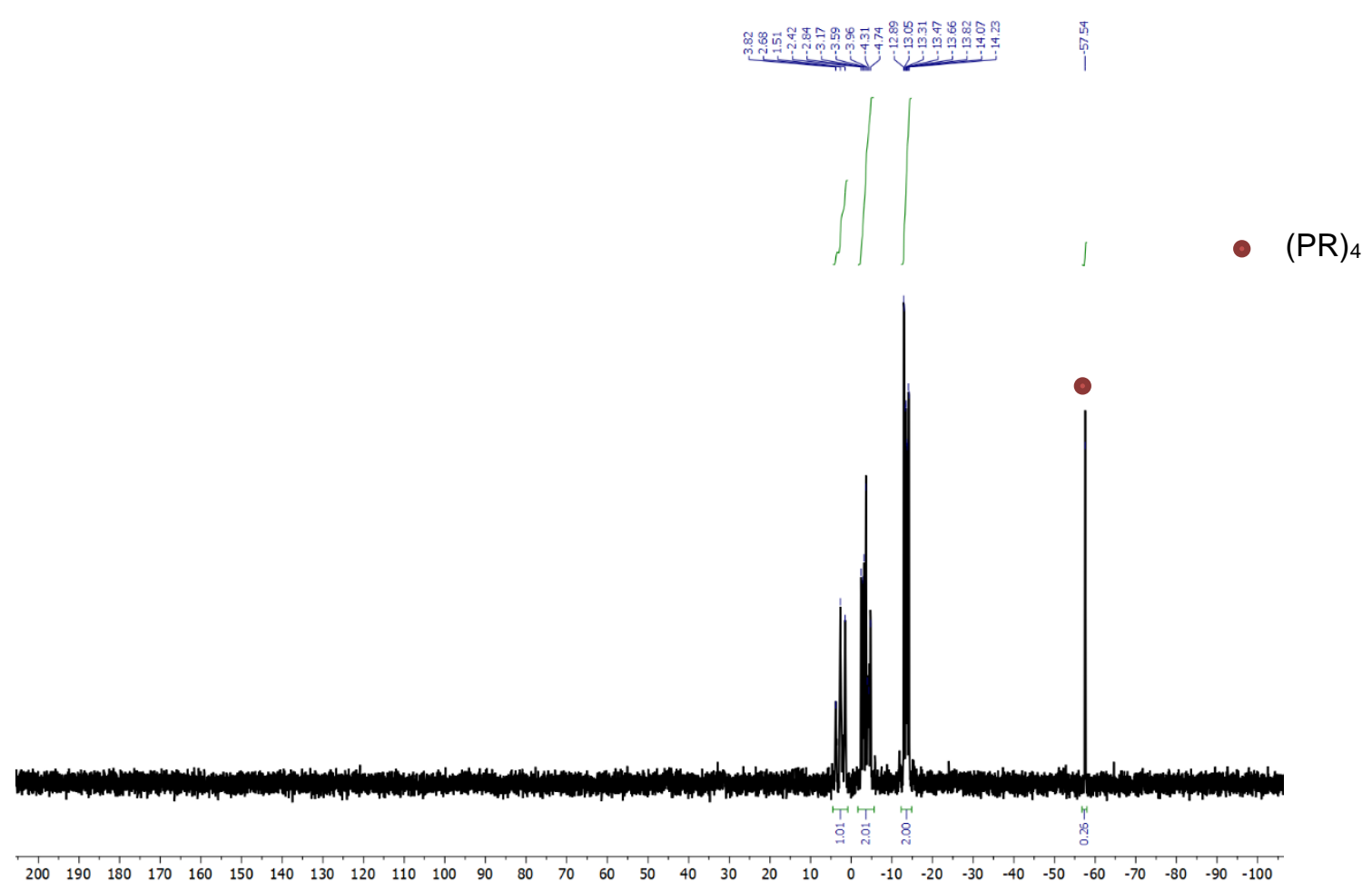

${ }^{13} \mathbf{C}\left\{{ }^{1} \mathrm{H}\right\}$ NMR $\left(101 \mathrm{MHz}, 298 \mathrm{~K}, \mathrm{C}_{6} \mathrm{D}_{6}\right)$ :

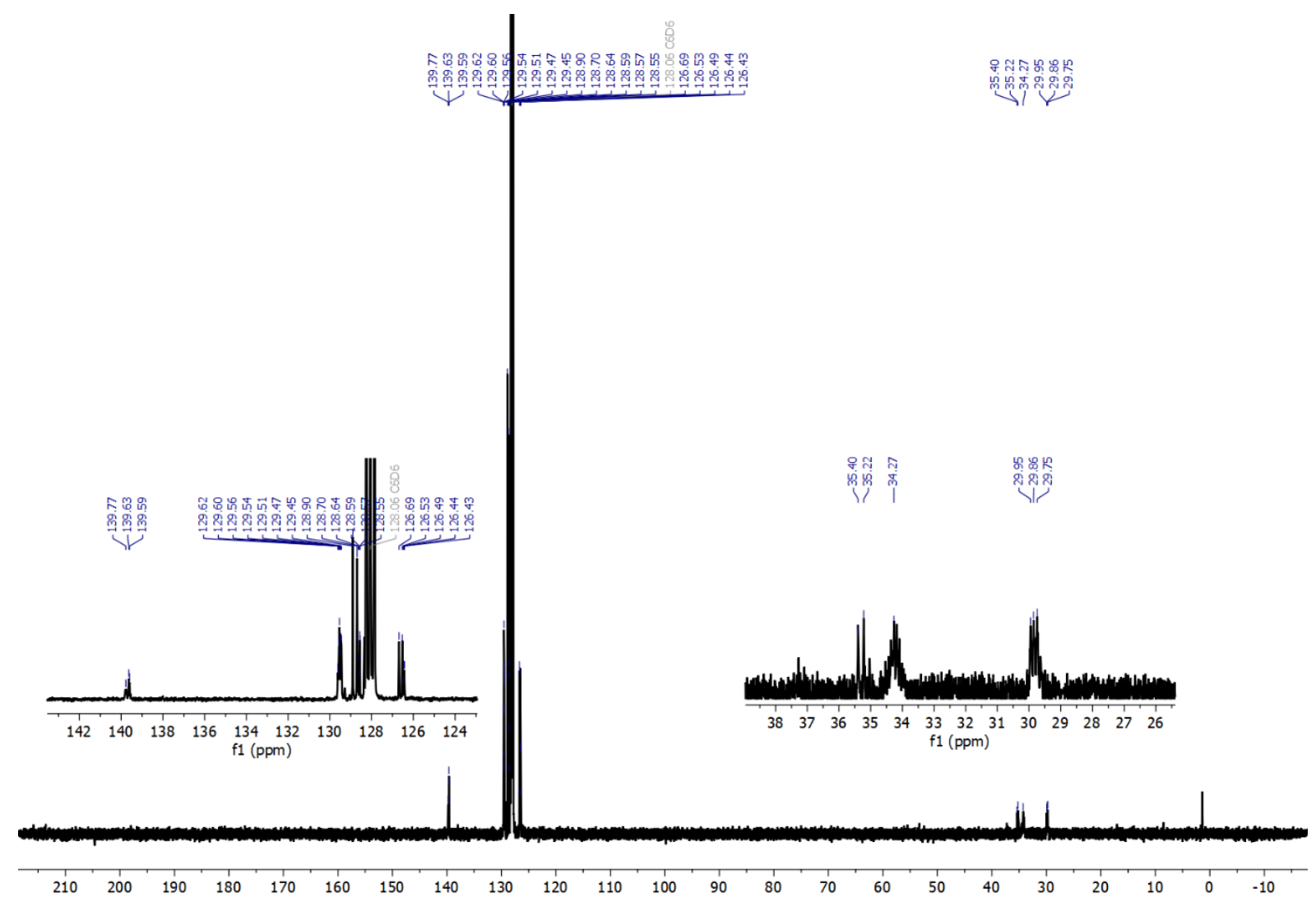

2c: 


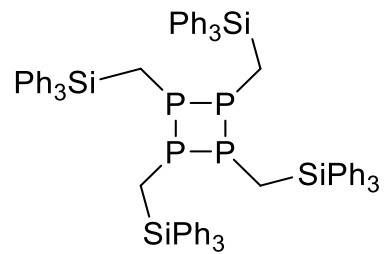

Isolated as a white solid in $38 \%$ yield. ${ }^{1} \mathrm{H}$ NMR $\left(500 \mathrm{MHz}, 298 \mathrm{~K}, \mathrm{CD}_{2} \mathrm{Cl}_{2}\right): \delta 7.37$ (d, $24 \mathrm{H}, \mathrm{J}=6.5 \mathrm{~Hz}$, Ar- $H$ ), 7.27 (t, $12 \mathrm{H}, \mathrm{J}=7.4 \mathrm{~Hz}, \mathrm{Ar}-H), 7.19($ at, $24 \mathrm{H}, \mathrm{J}=7.4 \mathrm{~Hz}, \mathrm{Ar}-H), 1.08\left(\mathrm{aq}, 8 \mathrm{H}, \mathrm{J}=5.1 \mathrm{~Hz},-\mathrm{P}-\mathrm{CH}_{2}\right.$ ). ${ }^{31} \mathrm{P}$ NMR $\left(162 \mathrm{MHz}, 298 \mathrm{~K}, \mathrm{CD}_{2} \mathrm{Cl}_{2}\right): \delta-46.5 .{ }^{13} \mathrm{C}\left\{{ }^{1} \mathrm{H}\right\} \mathrm{NMR}\left(101 \mathrm{MHz}, 298 \mathrm{~K}, \mathrm{CD}_{2} \mathrm{Cl}_{2}\right): \delta 136.7(\mathrm{Ar}-$ C), $135.4(\mathrm{Ar}-\mathrm{C}), 130.1$ (Ar-C), $128.1(\mathrm{Ar}-\mathrm{C}), 14.4\left(\mathrm{P}-\mathrm{CH}_{2}-\right)$. HRMS: $1217.3411 \mathrm{~m} / \mathrm{z}[\mathrm{M}+\mathrm{H}]^{+}$(calculated: 1217.3421). Melting point: $239-240^{\circ} \mathrm{C}$.

${ }^{1} \mathrm{H}$ NMR $\left(500 \mathrm{MHz}, 298 \mathrm{~K}, \mathrm{CD}_{2} \mathrm{Cl}_{2}\right)$ :

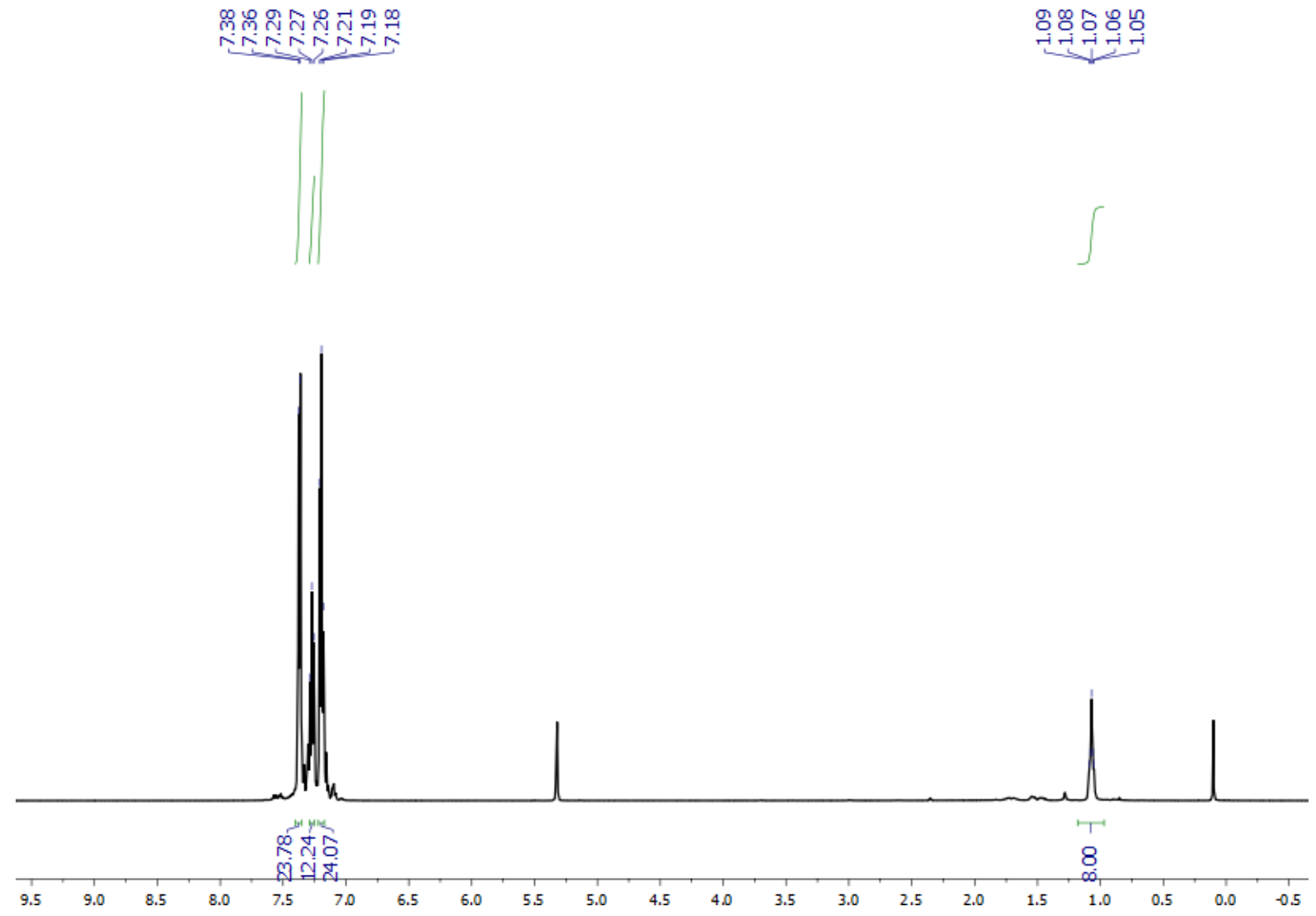

${ }^{31} \mathrm{P}$ NMR (162 MHz, $\left.298 \mathrm{~K}, \mathrm{CD}_{2} \mathrm{Cl}_{2}\right)$ : 


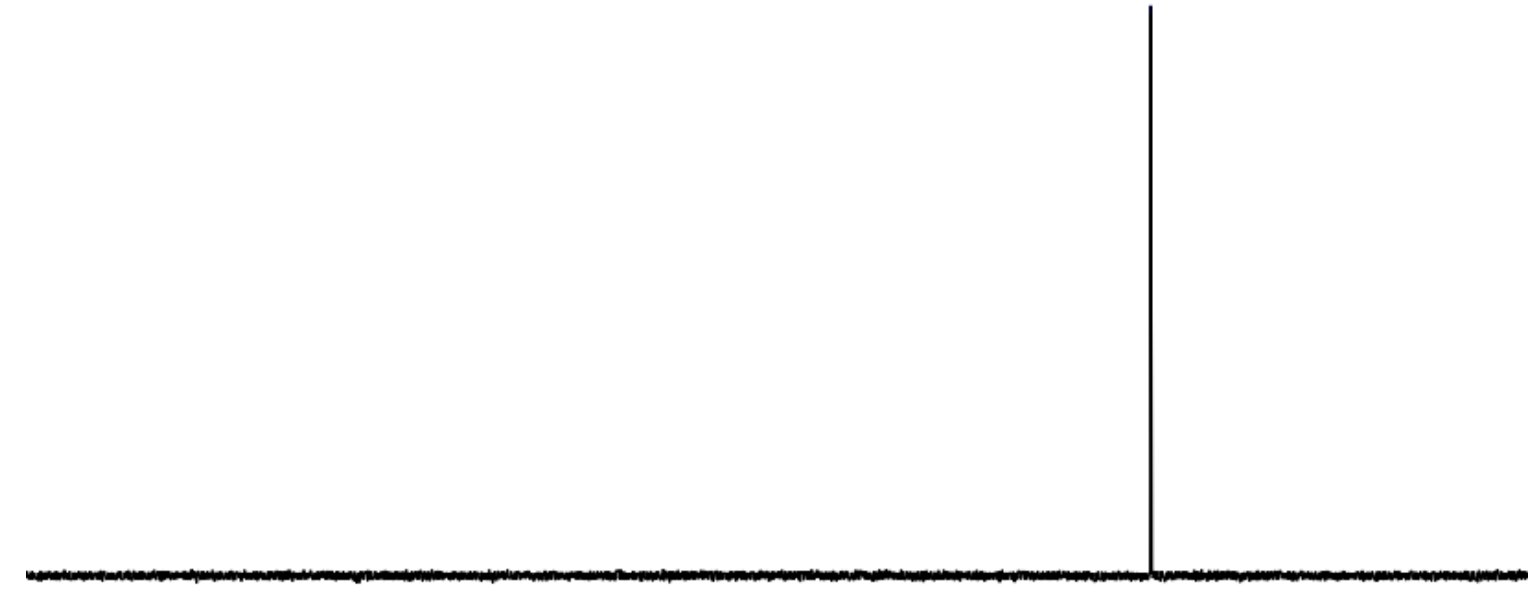

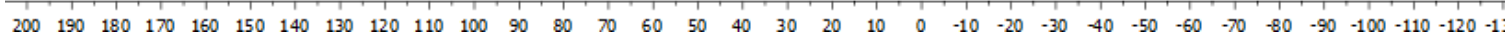
${ }^{13} \mathrm{C}\left\{{ }^{1} \mathrm{H}\right\}$ NMR $\left(101 \mathrm{MHz}, 298 \mathrm{~K}, \mathrm{CD}_{2} \mathrm{Cl}_{2}\right)$ :
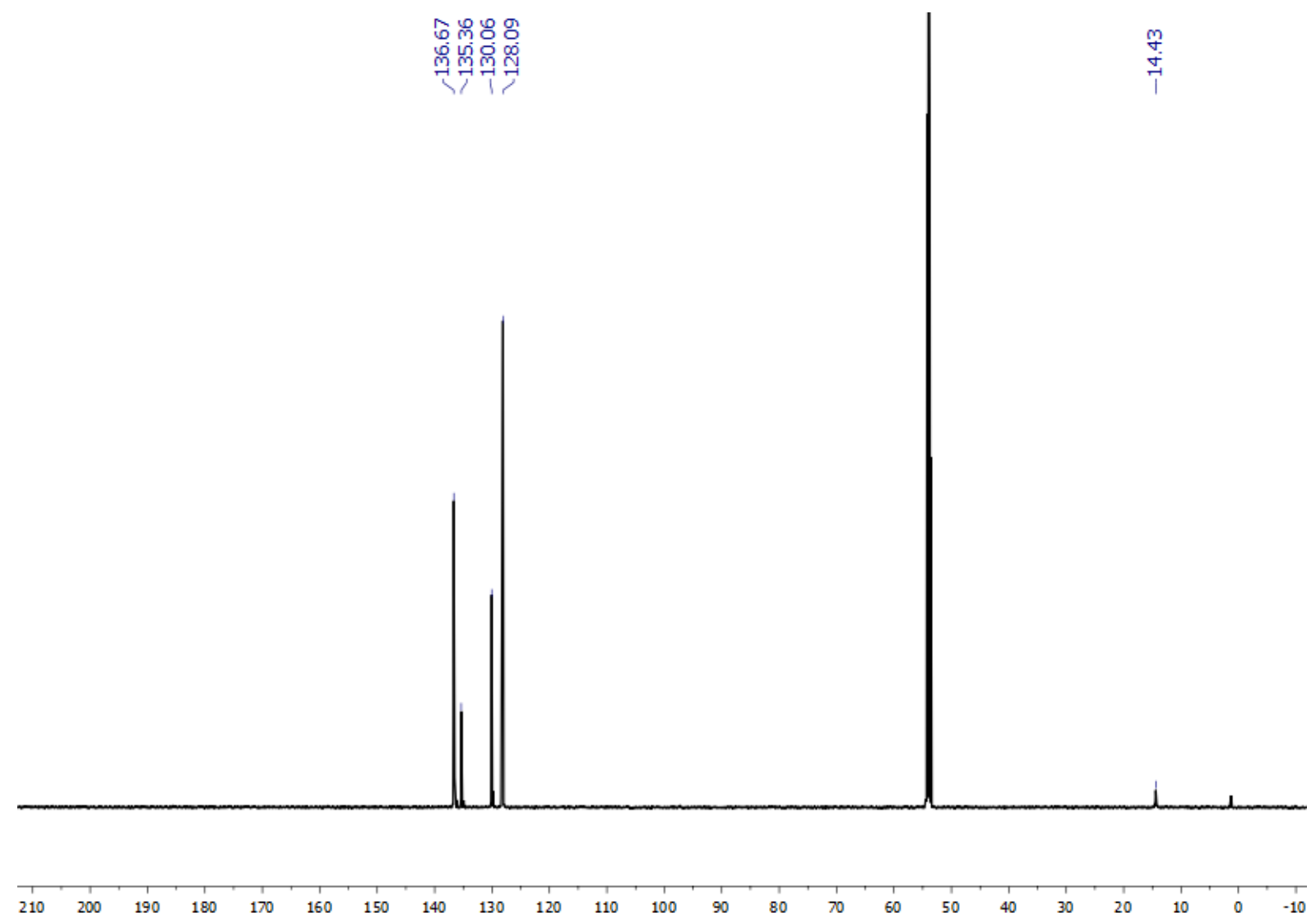

2d: 
<smiles>C[Si](C)(C)Cp1p(C[Si](C)(C)C)p(C[Si](C)(C)C)p([Si](C)(C)C)p1C[Si](C)(C)C</smiles>

Isolated as a colourless oil in $46 \%$ yield. ${ }^{1} \mathrm{H}$ NMR $\left(500 \mathrm{MHz}, 298 \mathrm{~K}, \mathrm{C}_{6} \mathrm{D}_{6}\right): \delta 1.57-1.31\left(\mathrm{~m}, 10 \mathrm{H}, \mathrm{P}-\mathrm{CH}_{2}\right.$ ), 0.29-0.18 (m, $45 \mathrm{H}, \mathrm{SiMe} 3) .{ }^{31} \mathrm{P}$ NMR $\left(162 \mathrm{MHz}, 298 \mathrm{~K}, \mathrm{C}_{6} \mathrm{D}_{6}\right): \delta 23.8-16.3(\mathrm{~m}) .{ }^{13} \mathrm{C}\left\{{ }^{1} \mathrm{H}\right\}$ NMR $(101$ $\left.\mathrm{MHz}, 298 \mathrm{~K}, \mathrm{C}_{6} \mathrm{D}_{6}\right):$ 14.2-13.2 (m, P-CH $\left.2^{-}\right)$, 8.7-7.8 (m, P- $\left.\mathrm{CH}_{2-}\right)$, 0.7- -0.5 (m, -SiMe $)$. HRMS: 591.1906 $\mathrm{m} / \mathrm{z}[\mathrm{M}+\mathrm{H}]^{+}$(calculated: 591.1911). IR (ATR, $\left.298 \mathrm{~K}\right): 2956(\mathrm{w}), 2280(\mathrm{w}), 1454(\mathrm{vw}), 1427(\mathrm{w}), 1330$ (w), 1248 (w), 1114 (s), 1065 (w), 998 (w), 811 (vs), 789 (s), 731 (s), 700 (vs) cm-1.

${ }^{1} \mathrm{H}$ NMR $\left(500 \mathrm{MHz}, 298 \mathrm{~K}, \mathrm{C}_{6} \mathrm{D}_{6}\right)$ :

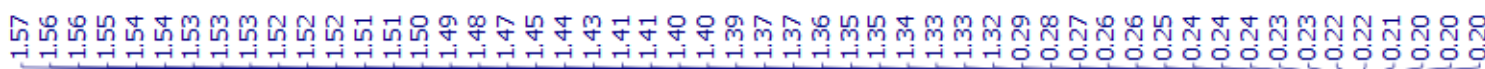

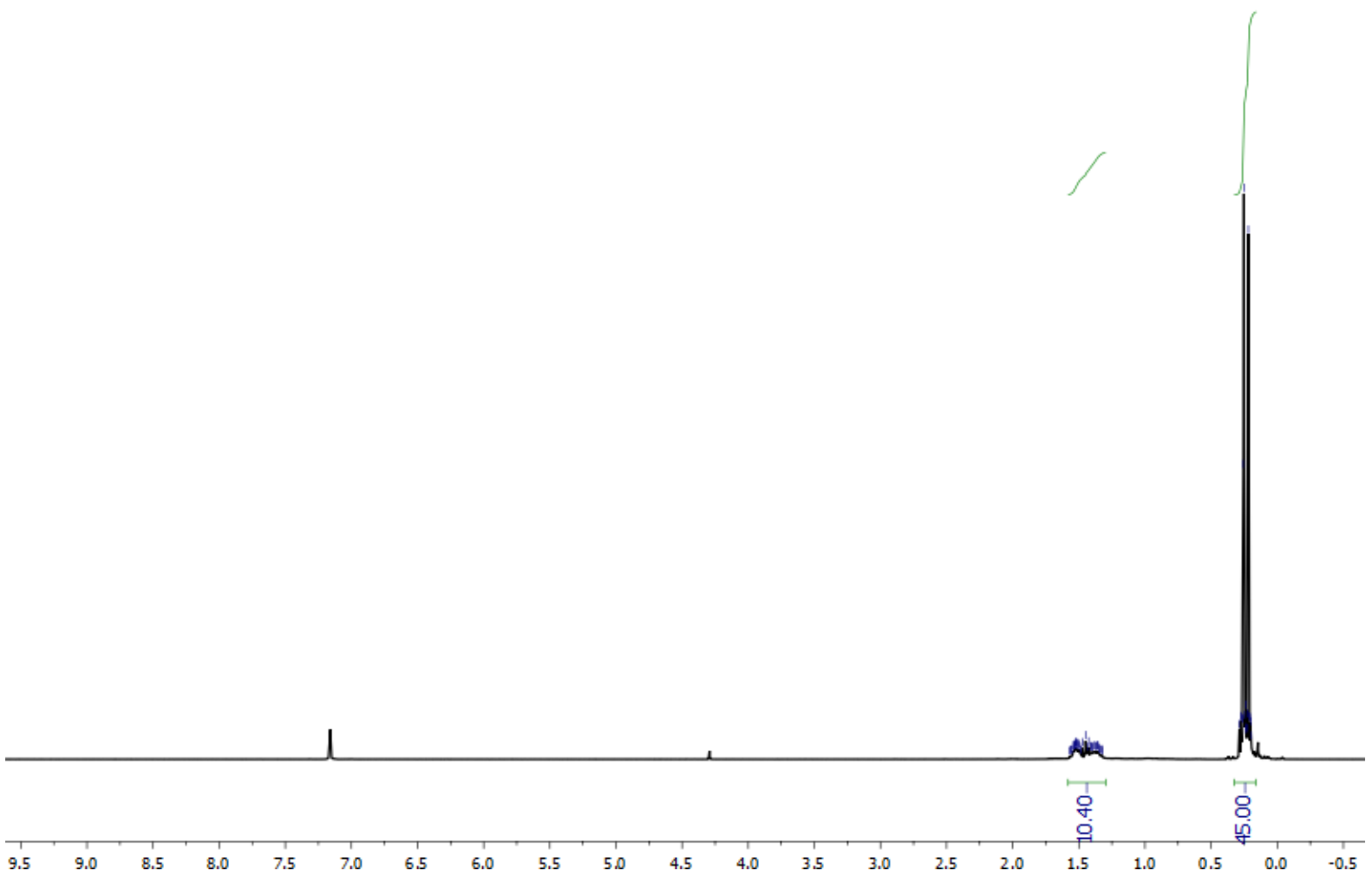

${ }^{31} \mathrm{P}$ NMR (162 MHz, $\left.298 \mathrm{~K}, \mathrm{C}_{6} \mathrm{D}_{6}\right)$ : 


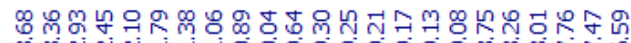

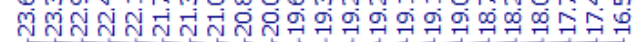

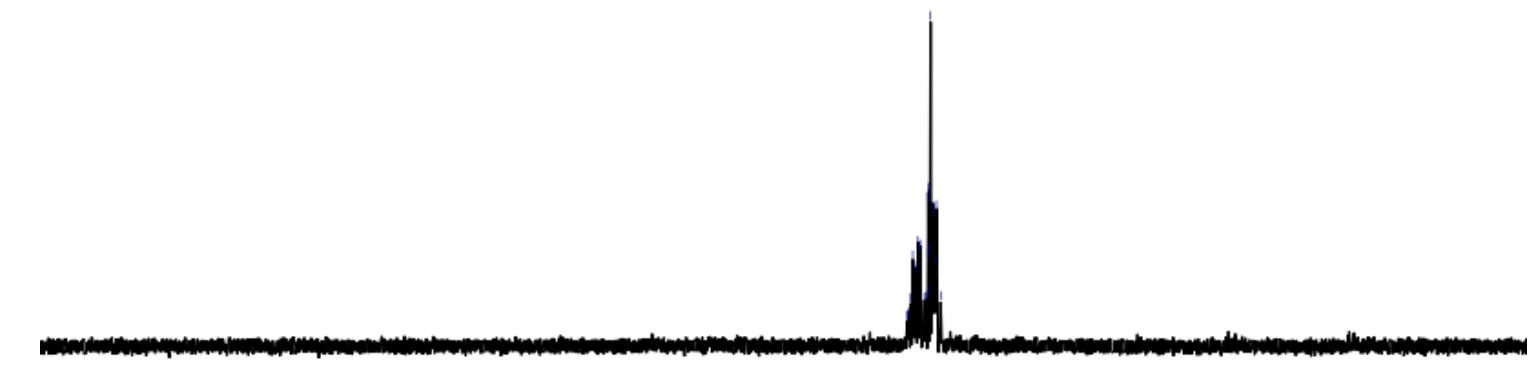

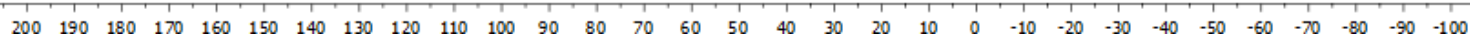
${ }^{13} \mathrm{C}\left\{{ }^{1} \mathrm{H}\right\}$ NMR $\left(101 \mathrm{MHz}, 298 \mathrm{~K}, \mathrm{C}_{6} \mathrm{D}_{6}\right):$

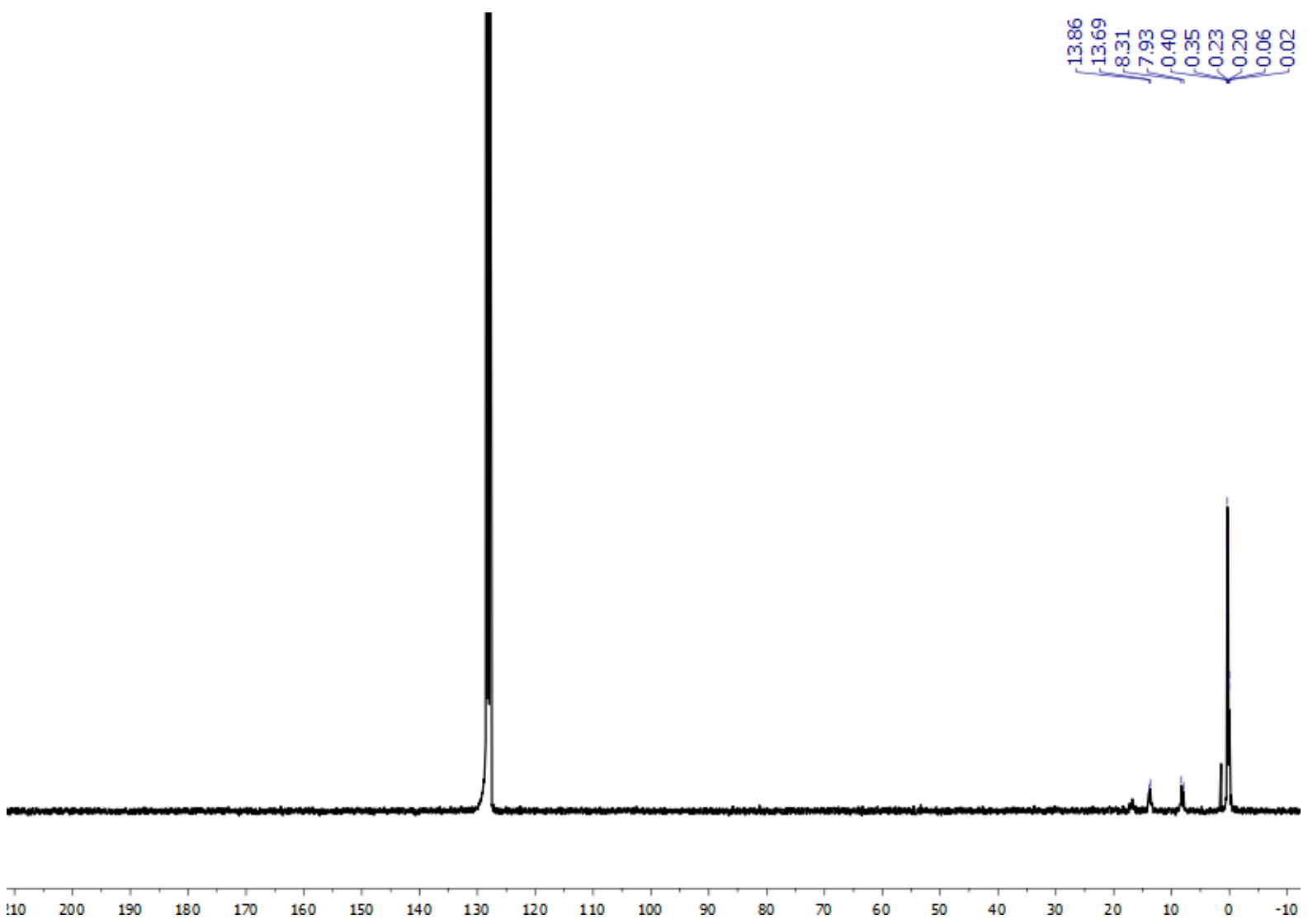

2e: 
<smiles>C[Si](C)(Cp1p(C[Si](C)(C)c2ccccc2)p(C[Si](C)(C)c2ccccc2)p([Si](C)(C)C[Si](C)(C)c2ccccc2)p1C[Si](C)(C)c1ccccc1)c1ccccc1</smiles>

Isolated as a colourless oil in $48 \%$ total yield as $47.6 \% \mathrm{P}_{5} \mathrm{R}_{5}, 0.0 \% \mathrm{P}_{6} \mathrm{R}_{6}, 0.4 \% \mathrm{P}_{4} \mathrm{R}_{4} .{ }^{1} \mathrm{H}$ NMR $(500 \mathrm{MHz}$, $\left.298 \mathrm{~K}, \mathrm{C}_{6} \mathrm{D}_{6}\right): \delta$ 7.40-7.28 (m, 10H, Ar- H), 7.08-6.97 (m, $\left.15 \mathrm{H}, \mathrm{Ar}-\mathrm{H}\right), 1.49-1.21\left(\mathrm{~m}, 10 \mathrm{H}, \mathrm{P}-\mathrm{CH}_{2}\right)$, 0.36$0.19(\mathrm{~m}, 30 \mathrm{H}, \mathrm{SiMe}) .{ }^{31} \mathrm{P}$ NMR $\left(162 \mathrm{MHz}, 298 \mathrm{~K}, \mathrm{C}_{6} \mathrm{D}_{6}\right): \delta 22.8-13.0(\mathrm{~m}) \cdot{ }^{13} \mathrm{C}\left\{{ }^{1} \mathrm{H}\right\} \mathbf{N M R}(101 \mathrm{MHz}, 298$ $\mathrm{K}, \mathrm{C}_{6} \mathrm{D}_{6}$ ): $\delta$ 139.3-139.1 (m, Ar-C), 134.4-134.0 (m, Ar-C), 129.6-129.4 (m, Ar-C), 128.2-128.1 (m, ArC), 13.2-12.4 (m, -P-CH $\left.2^{-}\right), 8.0-7.81$ (m, -P- $\left.\mathrm{CH}_{2}-\right),-0.8--1.7$ (m, SiMe $)$. HRMS: $901.2682 \mathrm{~m} / \mathrm{z}[\mathrm{M}+\mathrm{H}]^{+}$ (calculated: 901.2693). IR (ATR, 298 K): 3068 (vw), 3048 (vw), 3022 (vw), 2954 (w), 1589 (vw), 1487 (vw), 1426 (s), 1360 (w), 1300 (w), 1247 (s), 1113 (s), 811 (vs), 779 (vs), 728 (vs), 697 (vs) cm-1.

${ }^{1} \mathrm{H}$ NMR $\left(500 \mathrm{MHz}, 298 \mathrm{~K}, \mathrm{C}_{6} \mathrm{D}_{6}\right)$ :

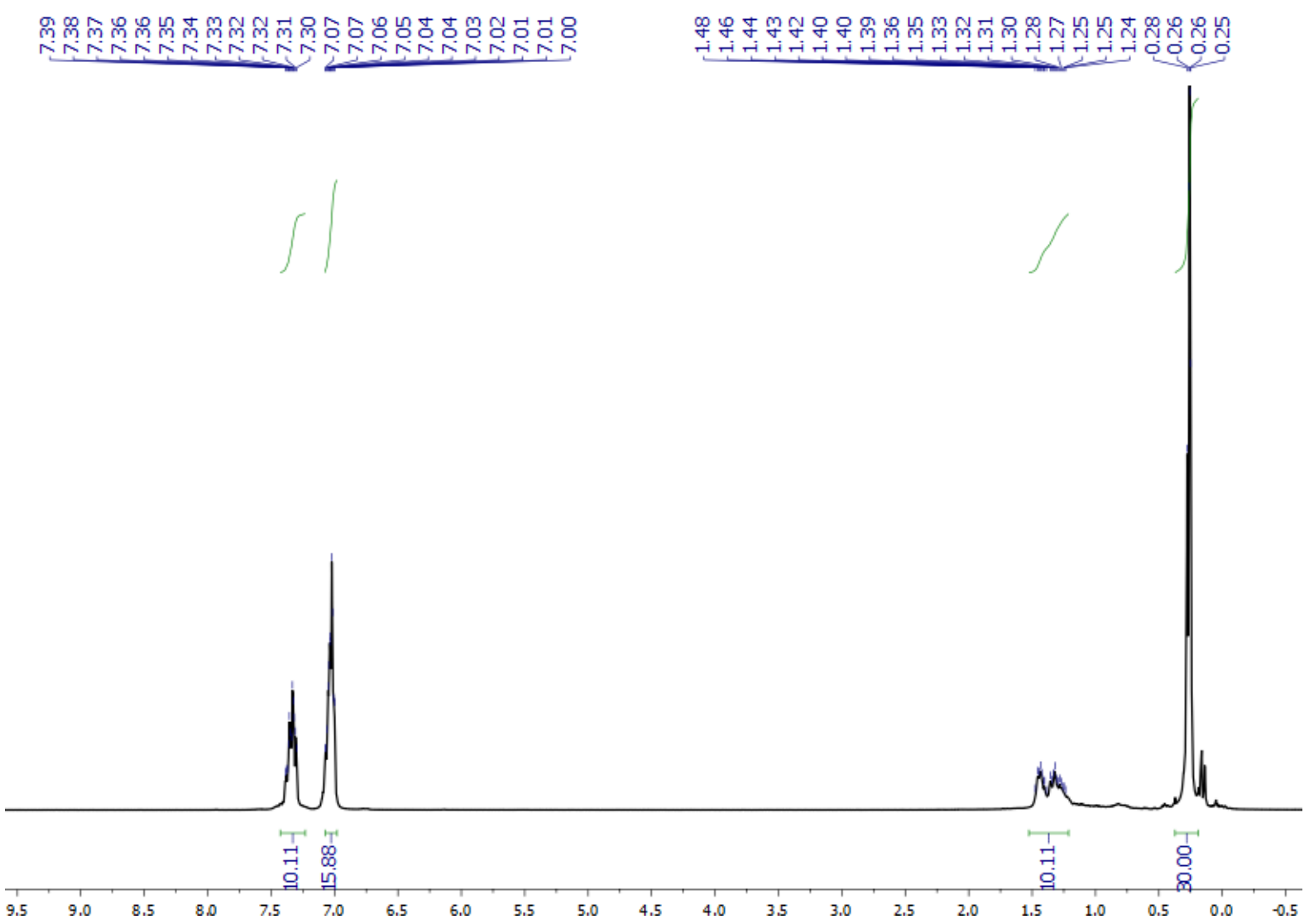

${ }^{31} \mathbf{P}$ NMR (162 MHz, $\left.298 \mathrm{~K}, \mathrm{C}_{6} \mathrm{D}_{6}\right)$ : 


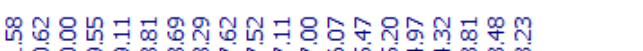

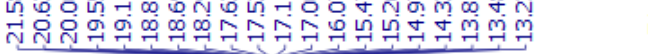

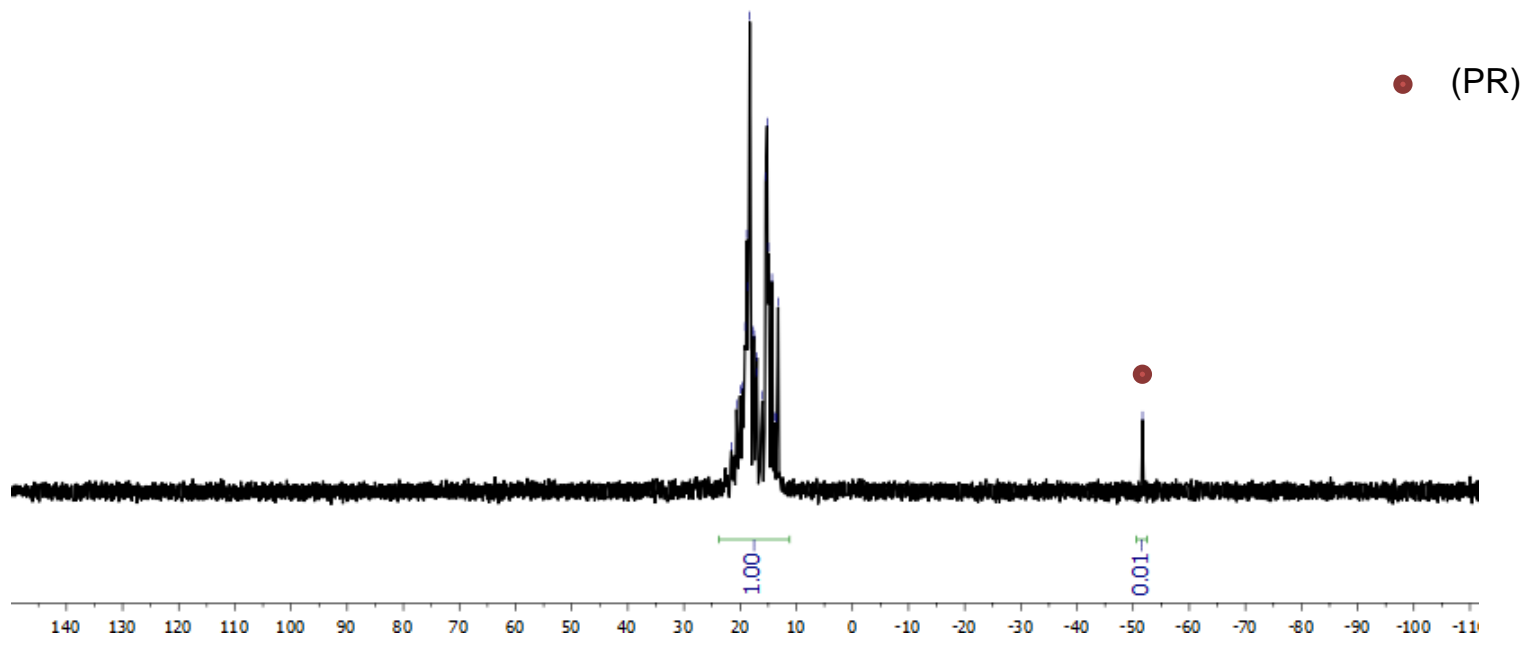

${ }^{13} \mathbf{C}\left\{{ }^{1} \mathrm{H}\right\}$ NMR $\left(101 \mathrm{MHz}, 298 \mathrm{~K}, \mathrm{C}_{6} \mathrm{D}_{6}\right)$ :

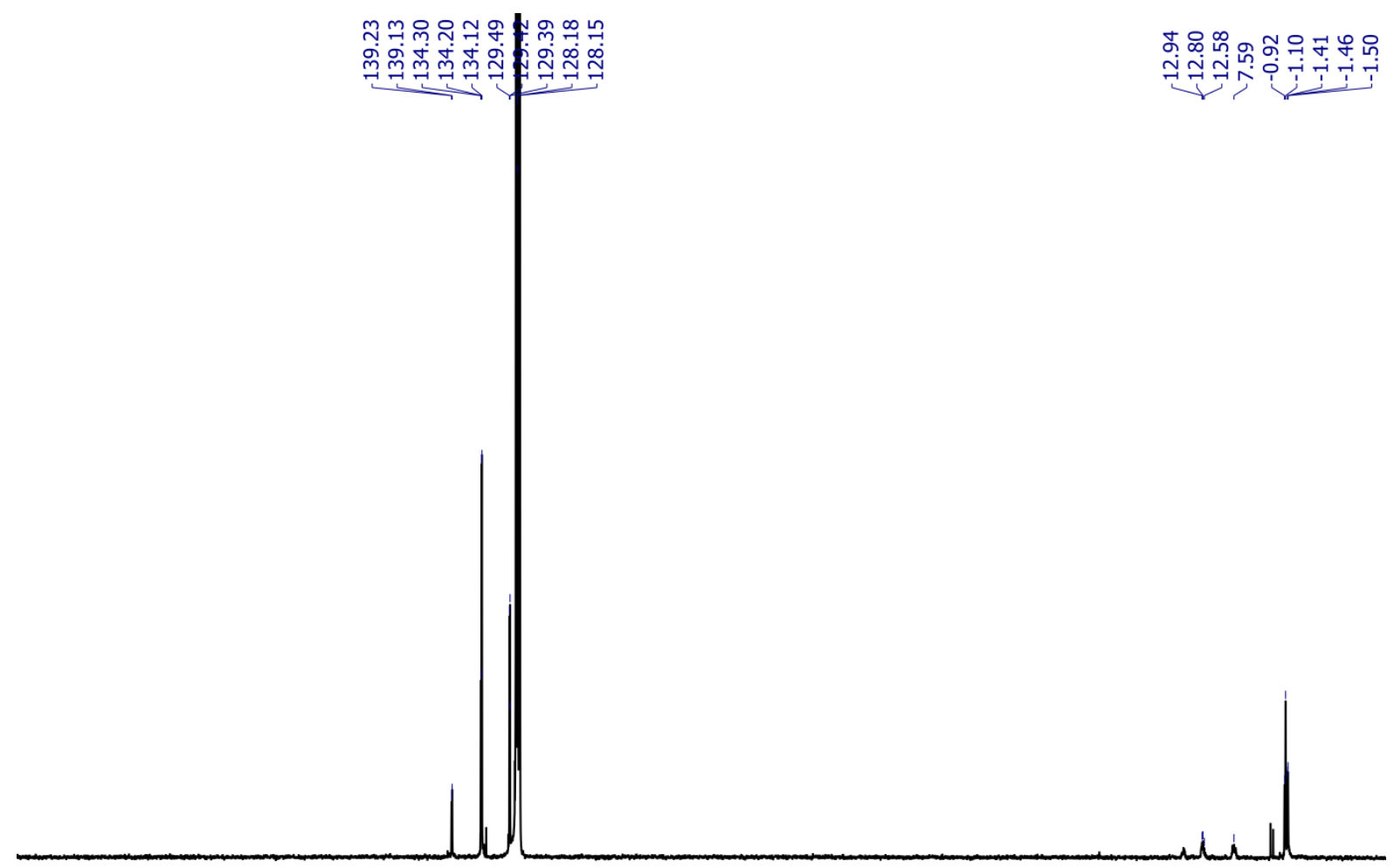

2f: 


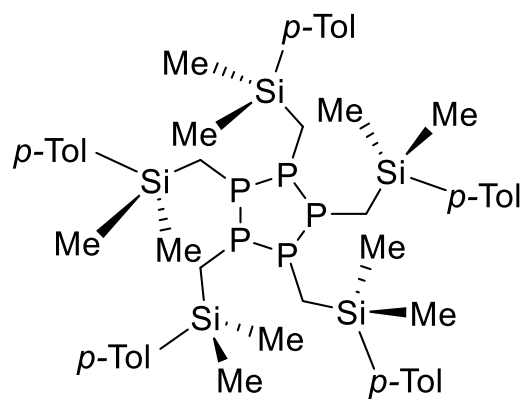

Isolated as a colourless oil in $41 \%$ total yield as $40.2 \% \mathrm{P}_{5} \mathrm{R}_{5}, 0.1 \% \mathrm{P}_{6} \mathrm{R}_{6}, 0.7 \% \mathrm{P}_{4} \mathrm{R}_{4} .{ }^{1} \mathrm{H}$ NMR $(500 \mathrm{MHz}$, $298 \mathrm{~K}, \mathrm{CD}_{2} \mathrm{Cl}_{2}$ ): $\delta$ 7.43-7.32 (m, 10H, Ar-H), 7.21-7.11 (m, $\left.10 \mathrm{H}, \mathrm{Ar}-\mathrm{H}\right), 2.33$ (s, 15H, Ar-Me) 1.36-1.16 $\left(\mathrm{m}, 10 \mathrm{H}, \mathrm{P}-\mathrm{CH}_{2}\right), 0.38-0.28(\mathrm{~m}, 30 \mathrm{H}, \mathrm{SiMe}) .{ }^{31} \mathrm{P}$ NMR $\left(162 \mathrm{MHz}, 298 \mathrm{~K}, \mathrm{CD}_{2} \mathrm{Cl}_{2}\right)$ : $\delta 22.3-14.3(\mathrm{~m})$. ${ }^{13} \mathrm{C}\left\{{ }^{1} \mathrm{H}\right\}$ NMR $\left(101 \mathrm{MHz}, 298 \mathrm{~K}, \mathrm{CD}_{2} \mathrm{Cl}_{2}\right):$ 139.5-139.3 (m, Ar-C), 136.1-135.7 (m, Ar-C), 134-5-134.0 (m, Ar-C), 129.2-128.9 (m, Ar-C), 21.7 (s, Ar-Me), 13.2-12.4 (m, - $\left.\mathrm{P}-\mathrm{CH}_{2}-\right)$, 8.2-7.3 (m, - $\left.\mathrm{P}-\mathrm{CH}_{2}-\right)$, -0.6- 1.6 (m, SiMe $)$. HRMS: $971.3471 \mathrm{~m} / \mathrm{z}$ [M+H] ${ }^{+}$(calculated: 971.3475$)$. IR (ATR, $\left.298 \mathrm{~K}\right): 3010$ (vw), 2954 (w), $1773(\mathrm{vw}), 1695(\mathrm{w}), 1603(\mathrm{w}), 1494(\mathrm{vw}), 1391(\mathrm{vw}), 1363(\mathrm{vw}), 1329(\mathrm{vw}), 1312(\mathrm{vw}), 1295(\mathrm{vw})$, 1246 (s), 1175 (w), 1106 (vs), 1083 (w), 1021 (w), 962 (w), 817 (vs), 793 (vs), 731 (vs), 714 (s), 692 (s) $\mathrm{cm}^{-1}$.

${ }^{1} \mathrm{H}$ NMR $\left(500 \mathrm{MHz}, 298 \mathrm{~K}, \mathrm{CD}_{2} \mathrm{Cl}_{2}\right)$ :

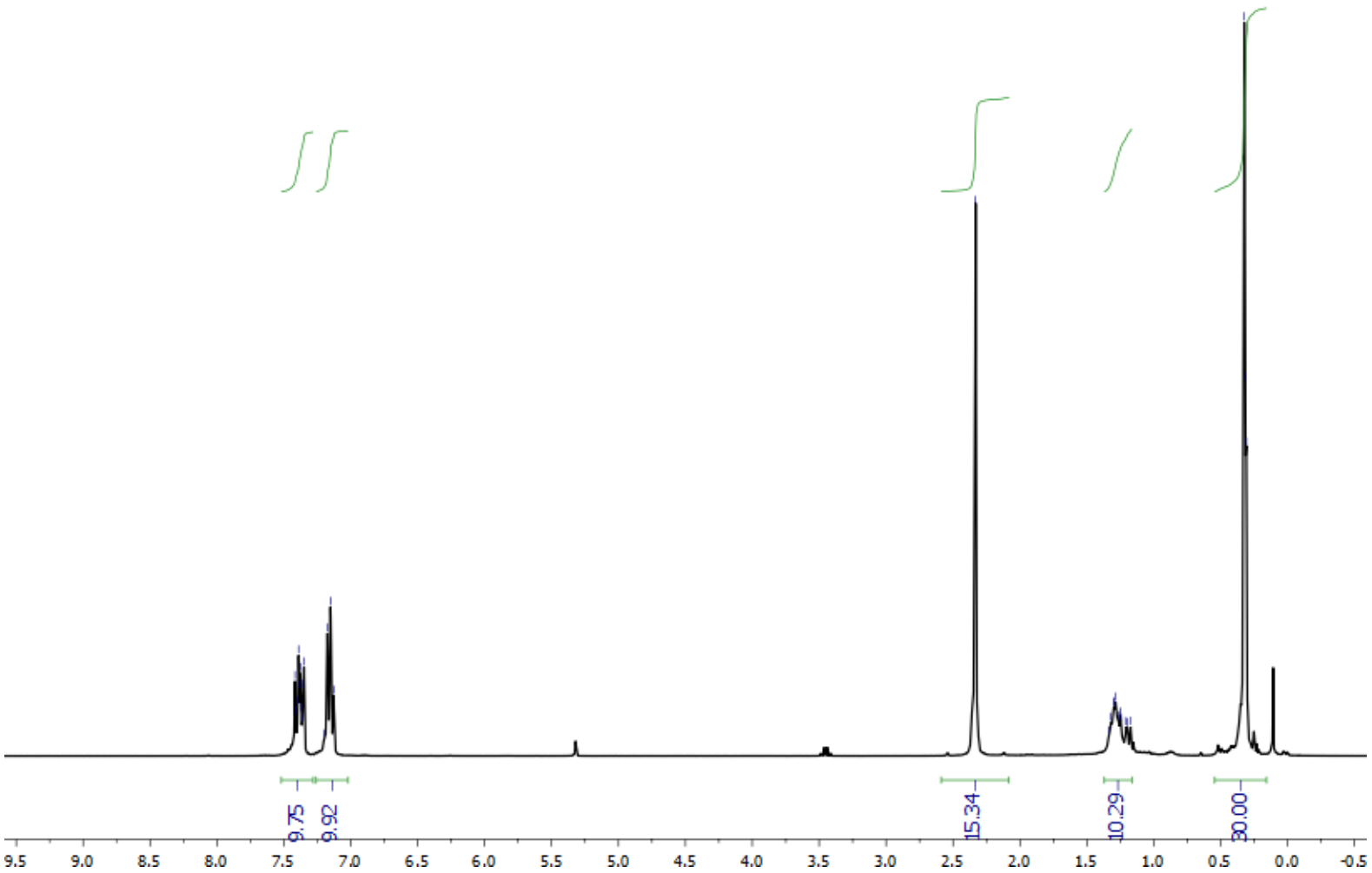

${ }^{31} \mathbf{P}$ NMR (162 MHz, $\left.298 \mathrm{~K}, \mathrm{CD}_{2} \mathrm{Cl}_{2}\right)$ : 


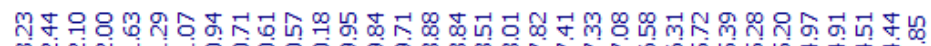

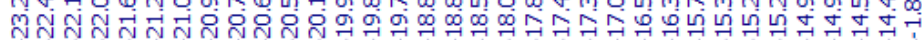

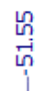

- $(\mathrm{PR})_{6}$

- $(\mathrm{PR})_{4}$

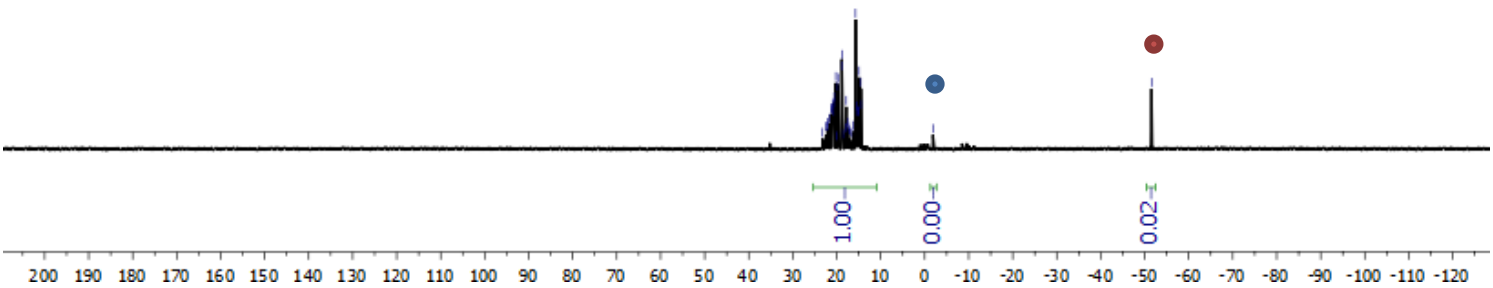

${ }^{13} \mathrm{C}\left\{{ }^{1} \mathrm{H}\right\}$ NMR $\left(101 \mathrm{MHz}, 298 \mathrm{~K}, \mathrm{CD}_{2} \mathrm{Cl}_{2}\right)$ :

นกำ

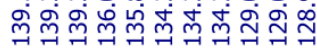

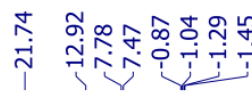

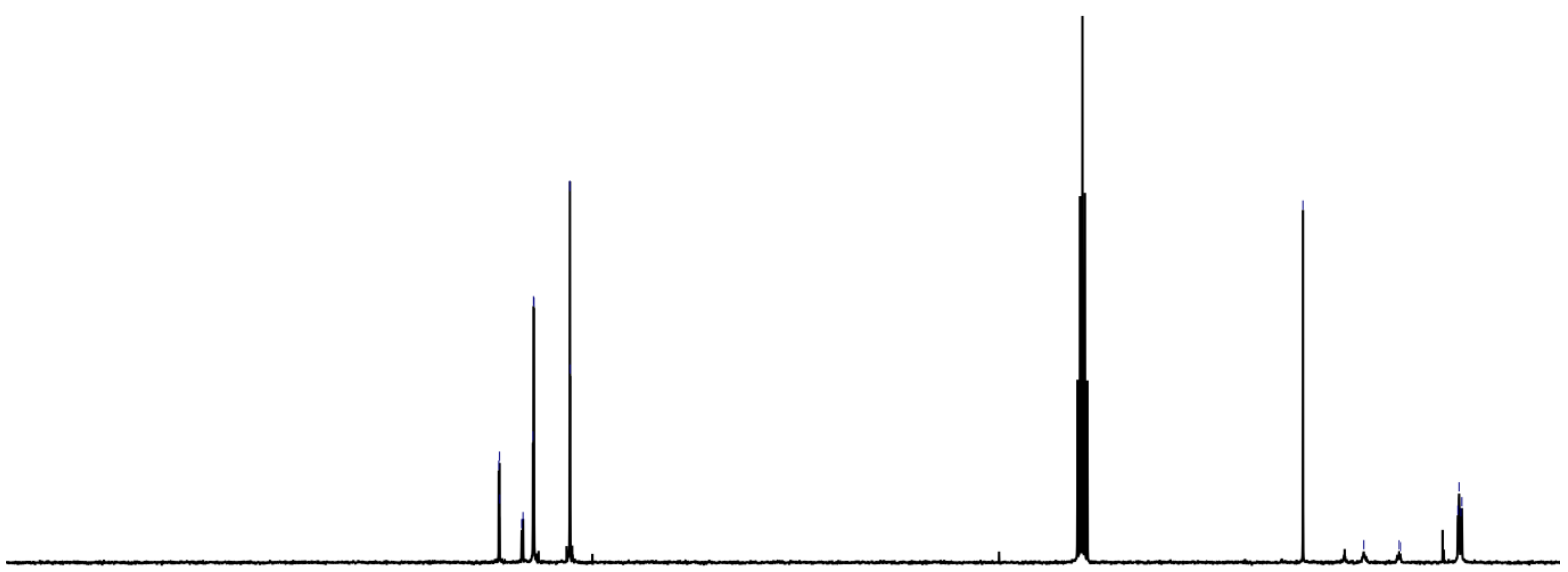

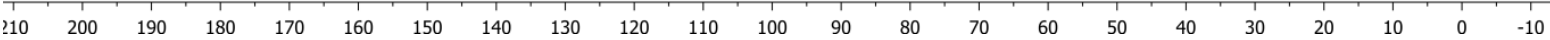




\section{Conversion for Alkyldichlorophosphines Without $\mathrm{Fe}(\mathrm{acac})_{3}$}

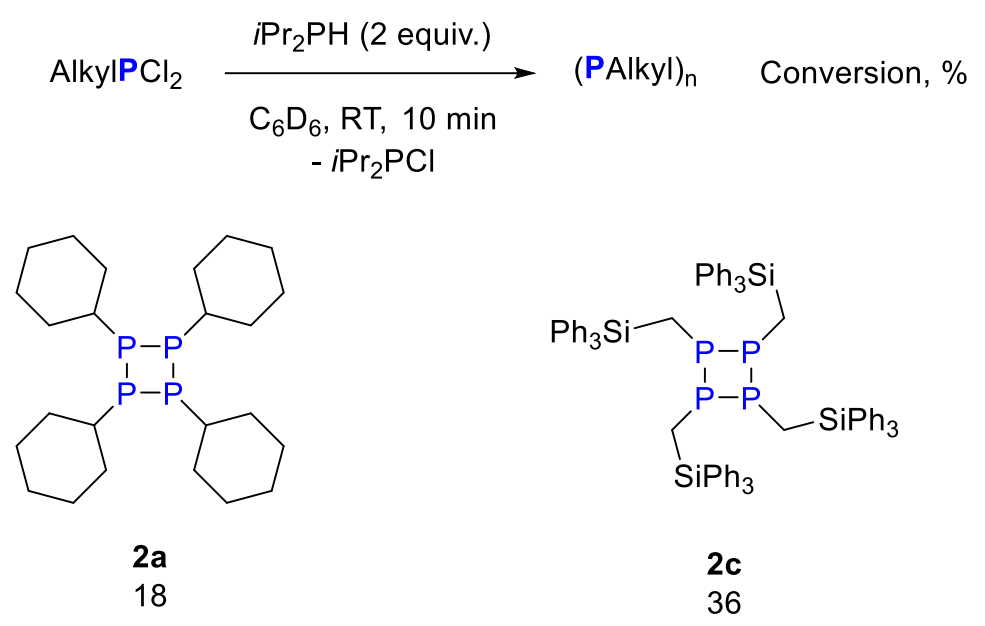<smiles>C[SiH2]CP1C(C[SiH3])P(C[SiH3])P1C[SiH2]C</smiles>

2d

33

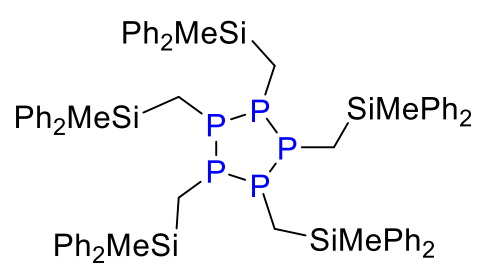

$2 e$

40

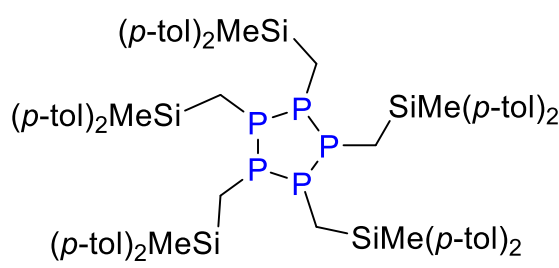

$2 \mathrm{f}$

45

Figure S1: Substrate Scope for Formation of Cyclopolyphosphines from Alkyldichlorophosphines in the Absence of $\mathrm{Fe}(\mathrm{acac})_{3}$. Conditions: $0.5 \mathrm{mmol} \mathrm{RPCl}_{2}, 1 \mathrm{mmol} \mathrm{Pr}_{2} \mathrm{PH}, 0.6 \mathrm{~mL} \mathrm{C}_{6} \mathrm{D}_{6}, \mathrm{RT}, 10 \mathrm{mins}$. Estimate conversions calculated by the integration of product signals against starting material via ${ }^{31} \mathrm{P}$ NMR spectroscopy.

Table S1: Formation of $\mathbf{2 d}$ using different additives. ${ }^{a}$

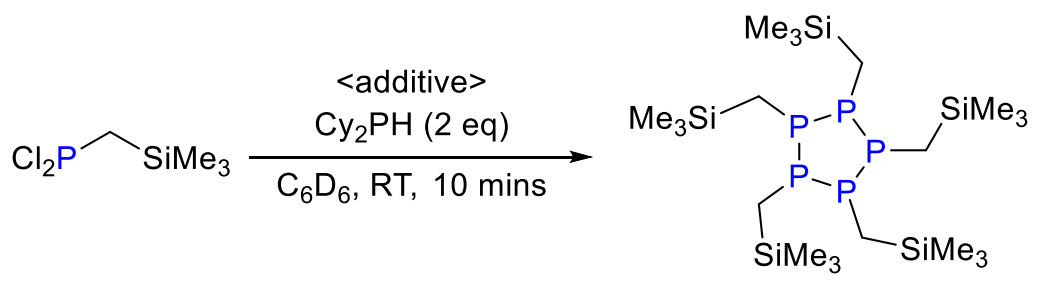

$\begin{array}{ccc}\text { Entry } & \text { Additive } & \begin{array}{c}\text { Conversion } \\ \%\end{array} \\ \mathbf{1} & 10 \mathrm{~mol} \% \mathrm{Fe}(\mathrm{acac})_{3} & >99 \\ \mathbf{2} & 2 \text { eq. } \mathrm{Et}_{3} \mathrm{~N} & 0 \\ \mathbf{3} & 2 \text { eq. } \mathrm{NaOtBu} & 34 \\ \mathbf{4} & 10 \mathrm{~mol} \% \mathrm{Ni}(\mathrm{acac})_{2} & 67 \\ \mathbf{5} & 10 \mathrm{~mol} \% \mathrm{~V}(\mathrm{O})(\mathrm{acac})_{3} & 78\end{array}$

aConditions: $\mathrm{Me}_{3} \mathrm{SiCH}_{2} \mathrm{PCl}_{2}$ (94 mg, $0.5 \mathrm{mmol}$ ), $0.6 \mathrm{~mL} \mathrm{C}_{6} \mathrm{D}_{6}$, additive (10 mol\% / 2 eq.), $\mathrm{Cy}_{2} \mathrm{PH}(220 \mu \mathrm{L}, 1 \mathrm{mmol})$. ${ }^{b}$ Estimate conversions calculated by the integration of product signals against starting material via ${ }^{31} \mathrm{P}$ NMR spectroscopy. 


\section{Optimisation of Formation of Aryl-diphosphines}

Table S2. Optimisation of Aryl-diphosphine Formation via Dehydrochlorinationa

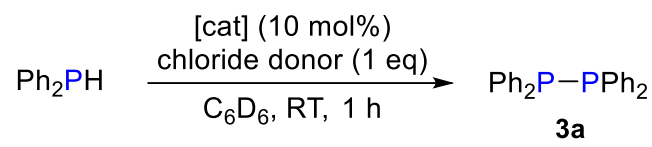

\begin{tabular}{|c|c|c|c|c|}
\hline Entry & Solvent & Catalyst & $\begin{array}{l}\text { Chloride } \\
\text { Donor }\end{array}$ & $\begin{array}{c}\text { Conversion / } \\
\%\end{array}$ \\
\hline 1 & $\mathrm{C}_{6} \mathrm{D}_{6}$ & None & $\mathrm{Cy}_{2} \mathrm{PCl}$ & 14 \\
\hline 2 & $\mathrm{C}_{6} \mathrm{D}_{6}$ & $\mathrm{Fe}(\mathrm{acac}) 3_{3}^{\mathrm{c}}$ & $\mathrm{Cy}_{2} \mathrm{PCl}$ & 58 \\
\hline 3 & $\mathrm{C}_{6} \mathrm{D}_{6}$ & $\mathrm{Fe}(\mathrm{acac})_{3}$ & $\mathrm{Cy}_{2} \mathrm{PCl}$ & 93 \\
\hline 4 & $\mathrm{C}_{6} \mathrm{D}_{6}$ & $\mathrm{Ni}(\text { acac })_{2}$ & $\mathrm{Cy}_{2} \mathrm{PCl}$ & 35 \\
\hline 5 & $\mathrm{C}_{6} \mathrm{D}_{6}$ & $\mathrm{VO}(\mathrm{acac})_{2}$ & $\mathrm{Cy}_{2} \mathrm{PCl}$ & 56 \\
\hline 6 & THF & $\mathrm{Fe}(\mathrm{acac})_{3}$ & $\mathrm{Cy}_{2} \mathrm{PCl}$ & 72 \\
\hline 7 & Toluene & $\mathrm{Fe}(\mathrm{acac})_{3}$ & $\mathrm{Cy}_{2} \mathrm{PCl}$ & 81 \\
\hline 8 & $\mathrm{Et}_{2} \mathrm{O}$ & $\mathrm{Fe}(\mathrm{acac})_{3}$ & $\mathrm{Cy}_{2} \mathrm{PCl}$ & 83 \\
\hline 9 & $\mathrm{DCM}$ & $\mathrm{Fe}(\mathrm{acac})_{3}$ & $\mathrm{Cy}_{2} \mathrm{PCl}$ & 79 \\
\hline 10 & THF & $\mathrm{Fe}(\mathrm{acac})_{3}$ & $\mathrm{Pr}_{2} \mathrm{PCl}$ & 72 \\
\hline 11 & $\mathrm{C}_{6} \mathrm{D}_{6}$ & $\mathrm{Fe}(\mathrm{acac})_{3}$ & $t \mathrm{Bu}_{2} \mathrm{PCl}$ & 0 \\
\hline 12 & $\mathrm{C}_{6} \mathrm{D}_{6}$ & $\mathrm{NaOtBu} u^{d}$ & $\mathrm{Cy}_{2} \mathrm{PCl}$ & 8 \\
\hline 13 & $\mathrm{C}_{6} \mathrm{D}_{6}$ & $\mathrm{NaHMDS}^{d}$ & $\mathrm{Cy}_{2} \mathrm{PCl}$ & 16 \\
\hline 14 & $\mathrm{C}_{6} \mathrm{D}_{6}$ & $\mathrm{Et}_{3} \mathrm{~N}^{\mathrm{d}}$ & $\mathrm{Cy}_{2} \mathrm{PCl}$ & 23 \\
\hline
\end{tabular}

aConditions: $0.5 \mathrm{mmol} \mathrm{Ph}_{2} \mathrm{PH}, 0.5 \mathrm{mmol}$ chloride donor, $0.6 \mathrm{~mL}$ solvent. ${ }^{\mathrm{b}}$ Estimate conversions calculated by integration of product signal against starting phosphine via ${ }^{31} \mathrm{P}$ NMR. ${ }^{\mathrm{c}} 5 \mathrm{~mol} \%$. ${ }^{\mathrm{d}} 100 \mathrm{~mol} \%$. 


\section{General Procedure for the Formation of Aryl-diphosphines via $\mathrm{Fe}(\mathrm{acac})_{3}$ Mediated Dehydrochlorination}

$\mathrm{Fe}(\mathrm{acac})_{3}(8.8 \mathrm{mg}, 10 \mathrm{~mol} \%)$ was added to a J-Young NMR tube in $0.6 \mathrm{~mL} \mathrm{C} 6 \mathrm{D}_{6}$. Aryl-phosphine $(0.25$ $\mathrm{mmol}$ ) was then added before the addition of dicyclohexylchlorophosphine $(0.25 \mathrm{mmol}, 55.2 \mu \mathrm{L})$. After one hour at room temperature (3d: 2 hours at room temperature), volatiles were removed in vacuo and the resulting residue was dissolved in toluene before passing through a short silica plug, eluting with more toluene. Volatiles were again removed in vacuo to obtain the product mixture. Spectroscopic yields were then obtained by integration against a triethylphosphite internal standard in the ${ }^{31} \mathrm{P}\left\{{ }^{1} \mathrm{H}\right\}$ inverse-gated NMR spectrum. 


\section{Spectroscopic Data Table 2}

3a<smiles>CP(c1ccccc1)P(c1ccccc1)c1ccccc1</smiles>

93\% spectroscopic yield. Not isolated. ${ }^{31} \mathrm{P}\left\{{ }^{1} \mathrm{H}\right\}$ NMR $\left(162 \mathrm{MHz}, 298 \mathrm{~K}, \mathrm{C}_{6} \mathrm{D}_{6}\right): \delta-14.6$. Crude data comparable to literature reports. ${ }^{23}$

${ }^{31} \mathrm{P}\left\{{ }^{1} \mathrm{H}\right\}$ NMR $\left(162 \mathrm{MHz}, 298 \mathrm{~K}, \mathrm{C}_{6} \mathrm{D}_{6}\right)$ :

- $3 a$

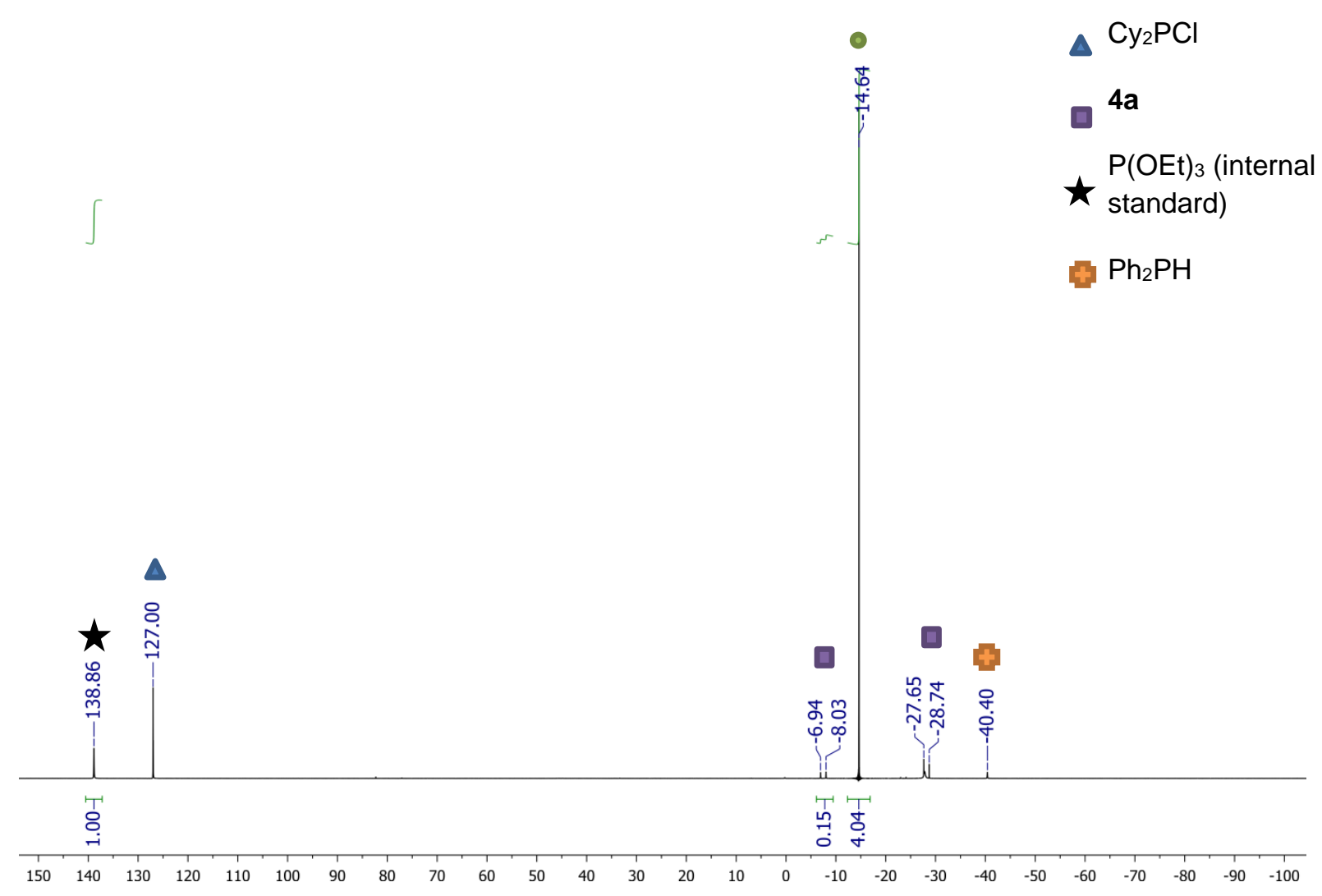


3b

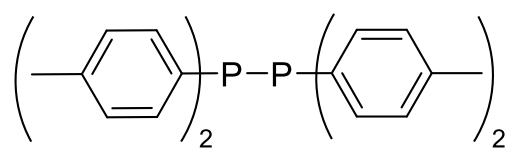

99\% spectroscopic yield. Not isolated. ${ }^{31} \mathrm{P}\left\{{ }^{1} \mathrm{H}\right\} \mathbf{N M R}\left(162 \mathrm{MHz}, 298 \mathrm{~K}, \mathrm{C}_{6} \mathrm{D}_{6}\right): \delta-17.3$. Crude data comparable to literature reports. ${ }^{23}$

${ }^{31} \mathrm{P}\left\{{ }^{1} \mathrm{H}\right\} \mathbf{N M R}\left(162 \mathrm{MHz}, 298 \mathrm{~K}, \mathrm{C}_{6} \mathrm{D}_{6}\right)$ :

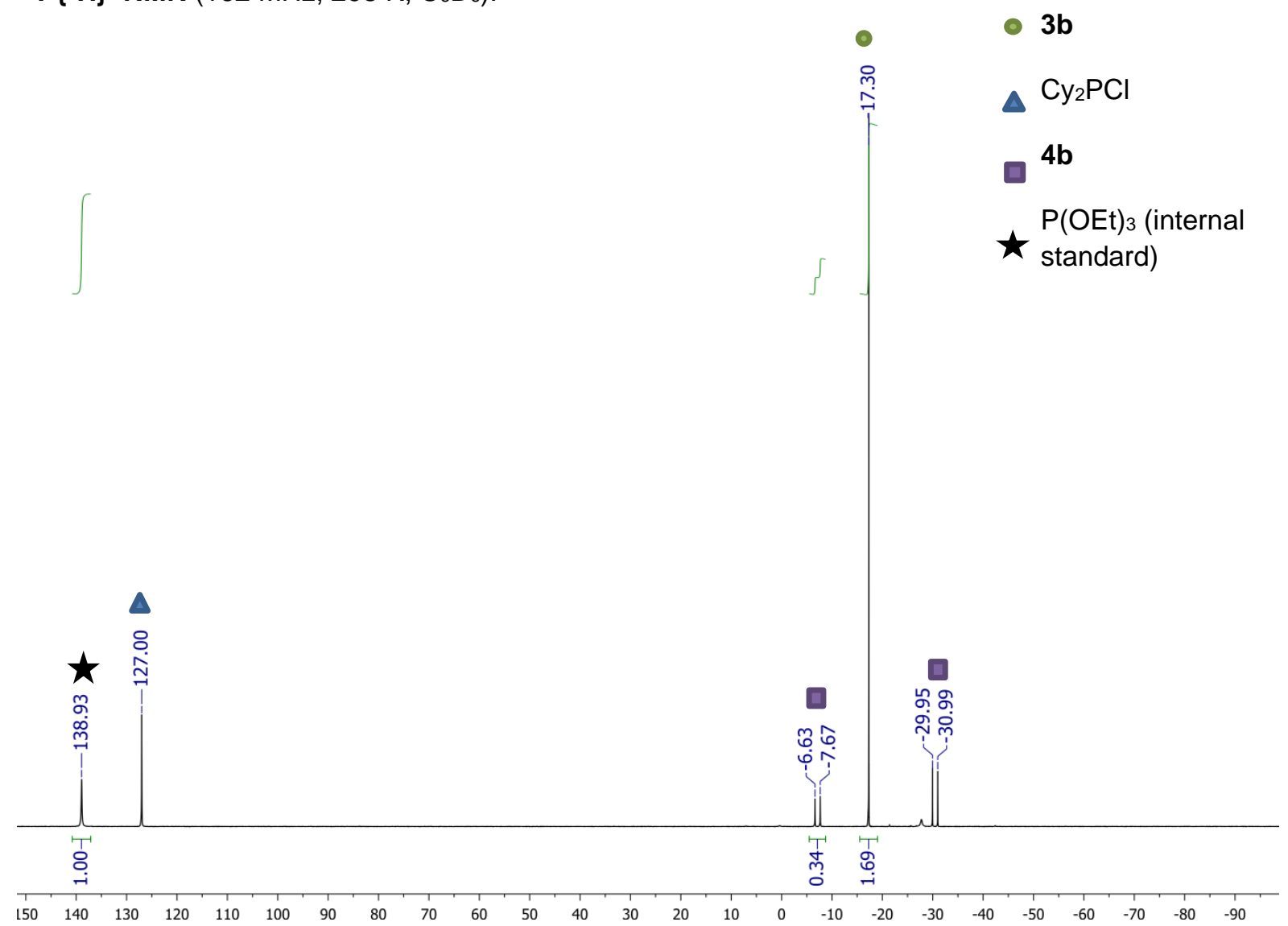


$3 c$

$(\mathrm{MeO}-\mathrm{I})_{2} \mathrm{P}-\mathrm{P}$

$88 \%$ spectroscopic yield. Not isolated. ${ }^{31} \mathrm{P}\left\{{ }^{1} \mathrm{H}\right\} \mathrm{NMR}\left(162 \mathrm{MHz}, 298 \mathrm{~K}, \mathrm{C}_{6} \mathrm{D}_{6}\right): \delta-18.8$. Crude data comparable to literature reports. ${ }^{23}$

${ }^{31} \mathbf{P}\left\{{ }^{1} \mathrm{H}\right\} \mathbf{N M R}\left(162 \mathrm{MHz}, 298 \mathrm{~K}, \mathrm{C}_{6} \mathrm{D}_{6}\right)$ :

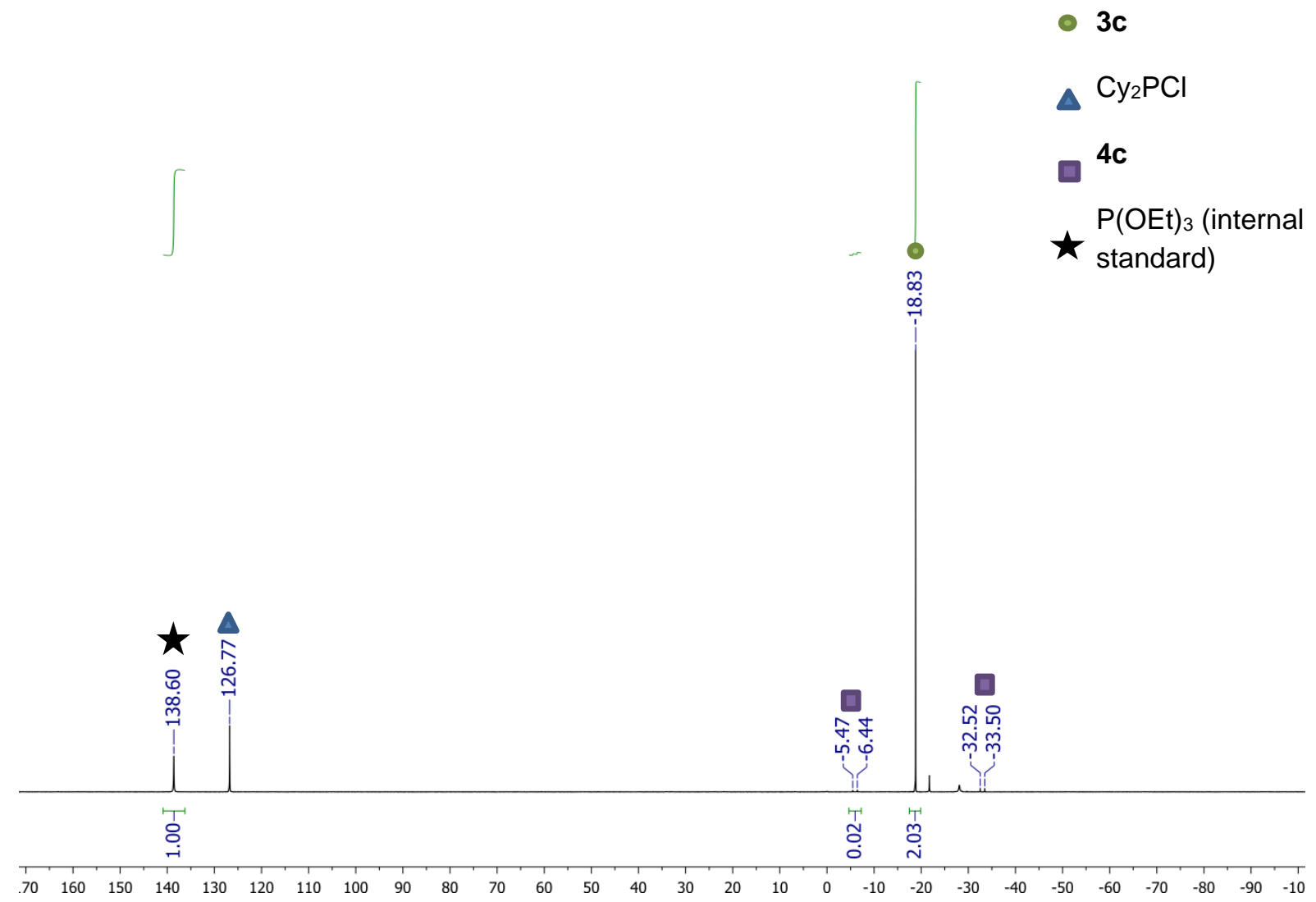


3d

$\left(\mathrm{F}_{3} \mathrm{C}-\mathrm{I}-\mathrm{P}-\mathrm{P}-\mathrm{CF}_{3}\right)_{2}$

$72 \%$ spectroscopic yield. Not isolated. ${ }^{31} \mathrm{P}\left\{{ }^{1} \mathrm{H}\right\} \mathbf{N M R}\left(162 \mathrm{MHz}, 298 \mathrm{~K}, \mathrm{C}_{6} \mathrm{D}_{6}\right): \delta-14.1$. Crude data comparable to literature reports. ${ }^{23}$

${ }^{31} \mathbf{P}\left\{{ }^{1} \mathrm{H}\right\}$ NMR (162 MHz, $\left.298 \mathrm{~K}, \mathrm{C}_{6} \mathrm{D}_{6}\right)$ :

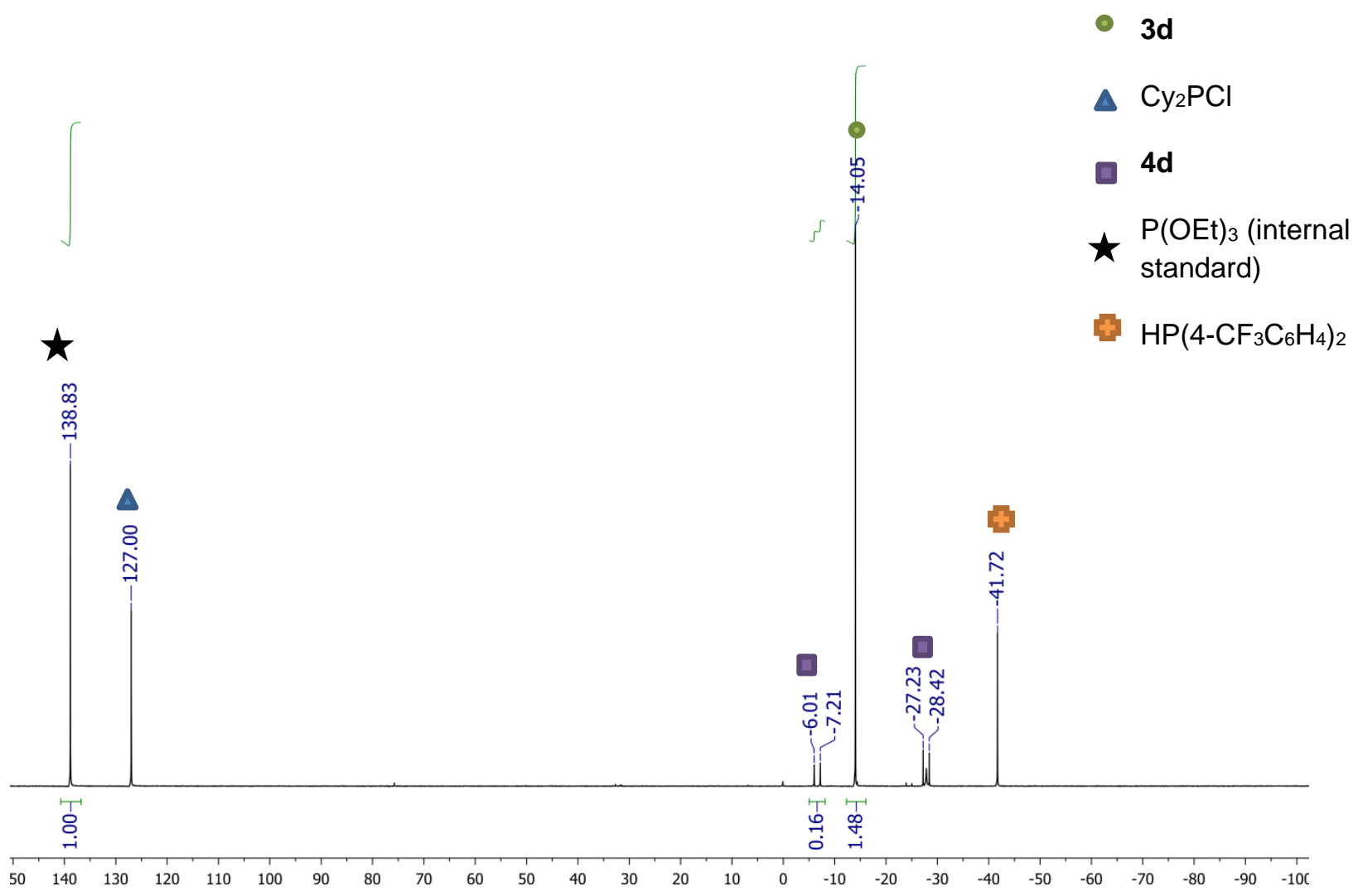


$3 e$

$\left(\mathrm{F}-\mathrm{I}-\mathrm{P}-\mathrm{P}-(\square-\mathrm{F})_{2}\right.$

$61 \%$ spectroscopic yield. Not isolated. ${ }^{31} \mathrm{P}\left\{{ }^{1} \mathrm{H}\right\}$ NMR $\left(162 \mathrm{MHz}, 298 \mathrm{~K}, \mathrm{C}_{6} \mathrm{D}_{6}\right): \delta-17.6$. Crude data comparable to literature reports. ${ }^{23}$

${ }^{31} \mathrm{P}\left\{{ }^{1} \mathrm{H}\right\}$ NMR (162 MHz, $\left.298 \mathrm{~K}, \mathrm{C}_{6} \mathrm{D}_{6}\right)$ :

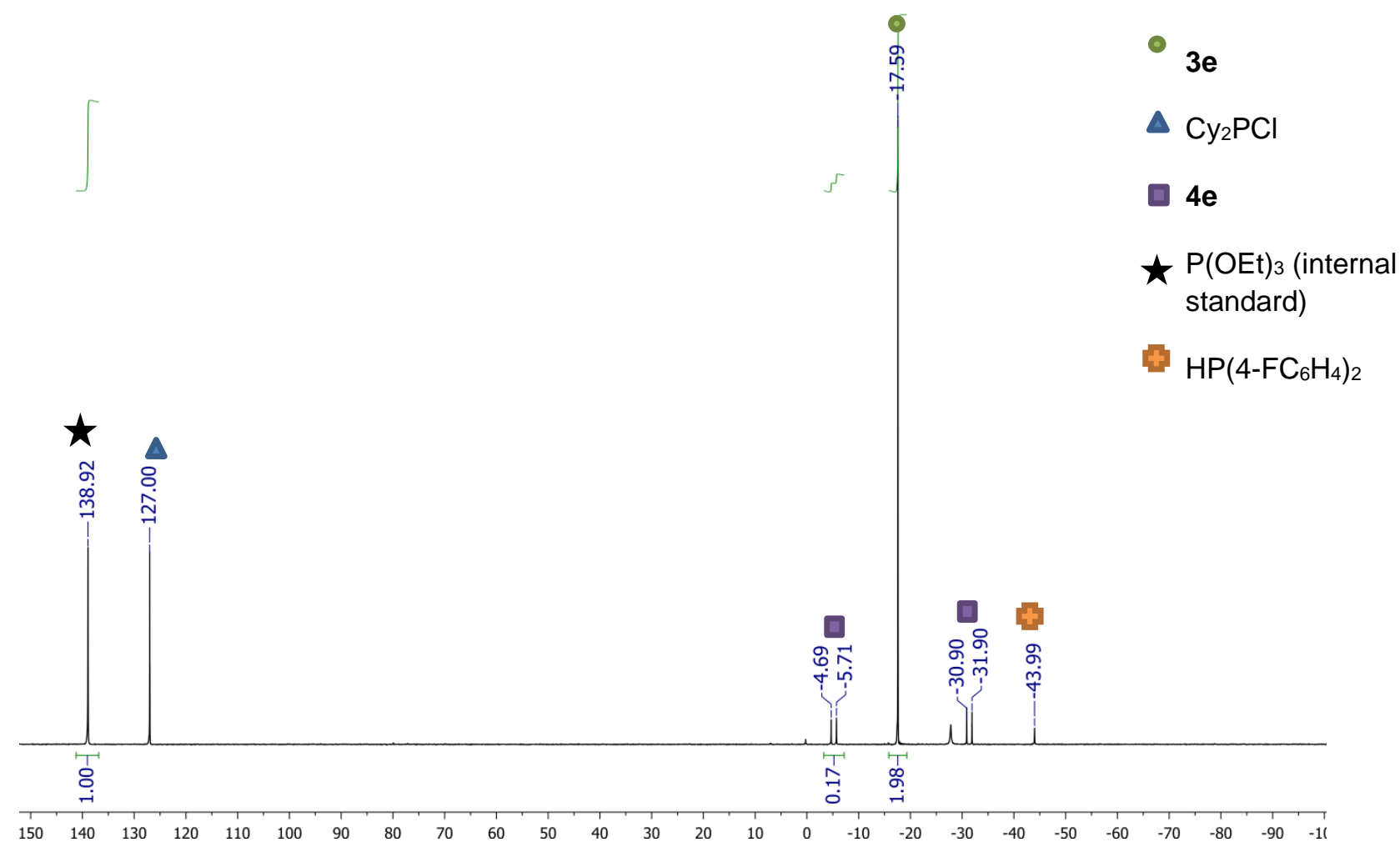


3f

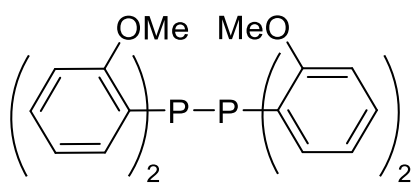

$43 \%$ spectroscopic yield. Not isolated. ${ }^{31} \mathrm{P}\left\{{ }^{1} \mathrm{H}\right\} \mathrm{NMR}\left(162 \mathrm{MHz}, 298 \mathrm{~K}, \mathrm{C}_{6} \mathrm{D}_{6}\right): \delta-44.8$. Crude data comparable to literature reports. ${ }^{23}$

${ }^{31} \mathrm{P}\left\{{ }^{1} \mathrm{H}\right\}\left(162 \mathrm{MHz}, 298 \mathrm{~K}, \mathrm{C}_{6} \mathrm{D}_{6}\right):$

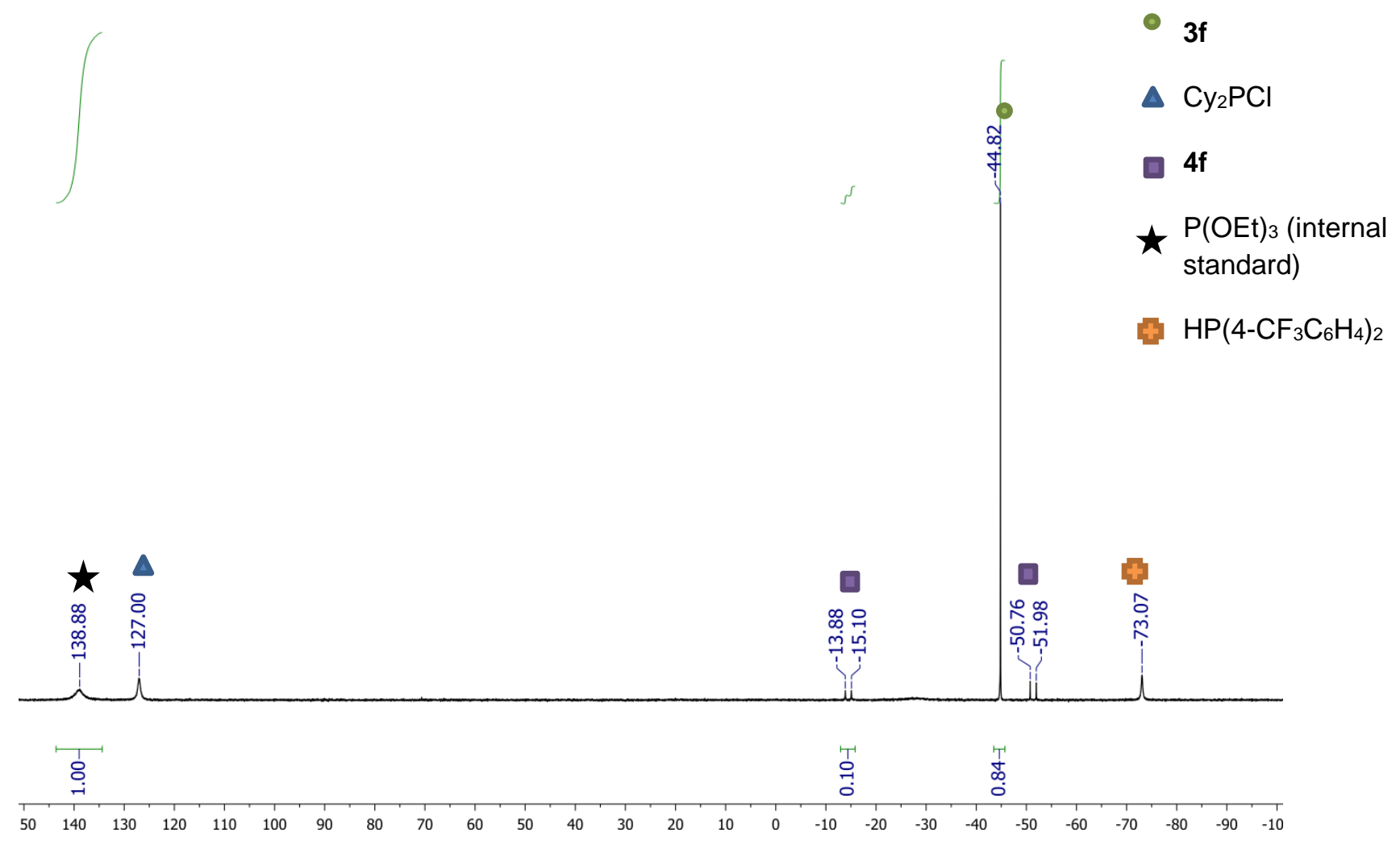




\section{Vacuum Transfer Experiment}

To investigate the hypothesis that the $\mathrm{HCl}$ liberated in the dehydrochlorination reaction was directly reacting with the $\mathrm{Fe}(\mathrm{acac})_{3}$ to yield acetylacetone (protonated ligand) and iron chloride, the reaction to form diphosphine 1a was repeated (at a slight scale up) and the resulting reaction mixture was distilled under vacuum.

Procedure:

$\mathrm{Fe}(\mathrm{acac})_{3}\left(25 \mathrm{mg}, 10 \mathrm{~mol} \%\right.$ ) was added to a J-Young Schlenk in $1.0 \mathrm{~mL} \mathrm{C}_{6} \mathrm{D}_{6}$. Diphenylphosphine (120 $\mu \mathrm{L}, 0.69 \mathrm{mmol})$ was then added before the addition of dicyclohexylchlorophosphine $(0.69 \mathrm{mmol}, 152$ $\mu \mathrm{L})$. After one hour at room temperature the volatiles in the reaction mixture were transferred via vacuum to a separate flask. To this distillate was added a dioxane internal standard $(20 \mu \mathrm{L})$ and the solution analysed by ${ }^{1} \mathrm{H}$ NMR.

Formation of $0.188 \mathrm{mmol}$ of acetyl acetone was observed by ${ }^{1} \mathrm{H}$ NMR, corresponding to an $89 \%$ conversion of Fe-bound ligand to free acetylacetone.

${ }^{1} \mathrm{H}$ NMR $\left(500 \mathrm{MHz}, 298 \mathrm{~K}, \mathrm{C}_{6} \mathrm{D}_{6}\right)$ :

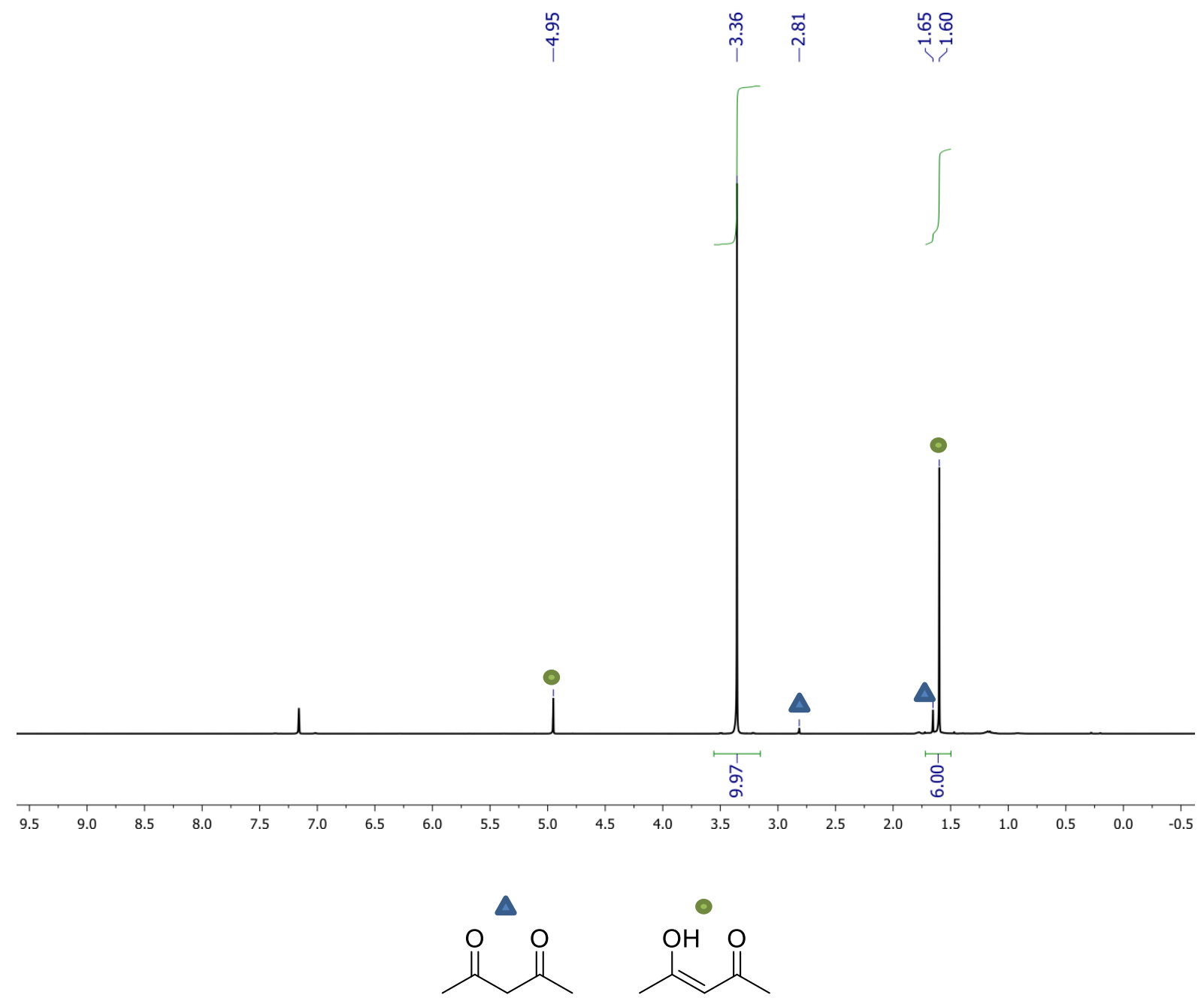




\section{Radical Trap Experiments}

For cyclopolyphosphine formation: In a J-Young's NMR tube containing $\mathrm{C}_{6} \mathrm{D}_{6}(0.6 \mathrm{~mL})$, dichlorophenylphosphine $(68 \mu \mathrm{L}, 0.5 \mathrm{mmol}$ ) was added along with (chloromethyl)cyclopropane $(46 \mu \mathrm{L}$, $0.5 \mathrm{mmol})$. Dicyclohexylphosphine $(220 \mu \mathrm{L}, 1.0 \mathrm{mmol})$ was then added. After $10 \mathrm{mins}$ at RT, $93 \%$ conversion to $\mathrm{P}_{5} \mathrm{Ph}_{5}(\mathbf{1 a})$ was observed by ${ }^{31} \mathrm{P}$ NMR.

For diphosphine formation: In a J-Young's NMR tube containing $\mathrm{C}_{6} \mathrm{D}_{6}(0.6 \mathrm{~mL})$, diphenylphosphine $(87 \mu \mathrm{L}, 0.5 \mathrm{mmol})$ was added along with (chloromethyl)cyclopropane $(46 \mu \mathrm{L}, 0.5 \mathrm{mmol})$. chlorodicyclohexylphosphine $(110 \mu \mathrm{L}, 1.0 \mathrm{mmol})$ was then added. After 10 mins at RT, $89 \%$ conversion to $\mathrm{P}_{2} \mathrm{Ph}_{4}(\mathbf{3 a})$ was observed by ${ }^{31} \mathrm{P} \mathrm{NMR}$. 


\section{HCI Stability Experiment}

To test if the cyclopolyphosphines were unstable to $\mathrm{HCl}$ (and hence the $\mathrm{Fe}(\mathrm{acac})_{3}$ was necessary in some cases to quench excess $\mathrm{HCl}$ before decomposition), an experiment was set up to bubble $\mathrm{HCl}$ gas through a solution of $\mathbf{2 c}$.

Following a literature procedure to produce $\mathrm{HCl}$ gas, ${ }^{24} \mathrm{CaCl}_{2}(5 \mathrm{~g})$ was placed in a three-necked round-bottomed flask with a dropping funnel containing $37 \% \mathrm{HCl}(10 \mathrm{~mL})$ attached. A cannula was bridged between this flask and a Schlenk tube containing $40 \mathrm{mg} 2 \mathrm{c}$ in $5 \mathrm{~mL} \mathrm{DCM}$. $\mathrm{HCl}$ was added slowly to the $\mathrm{CaCl}_{2}$ at a rate to maintain constant bubbling of $\mathrm{HCl}$ through the solution of $\mathbf{2 b}$. After 30 mins of bubbling, volatiles were removed in vacuo. Analysis of the resulting solid showed complete degradation of the $\mathbf{2} \mathbf{c}$ to $\mathrm{Ph}_{3} \mathrm{SiCH}_{2} \mathrm{PH}_{2}$ (an oxide signal was also observed).

${ }^{31} \mathbf{P}$ NMR (162 MHz, $\left.298 \mathrm{~K}, \mathrm{C}_{6} \mathrm{D}_{6}\right)$ :

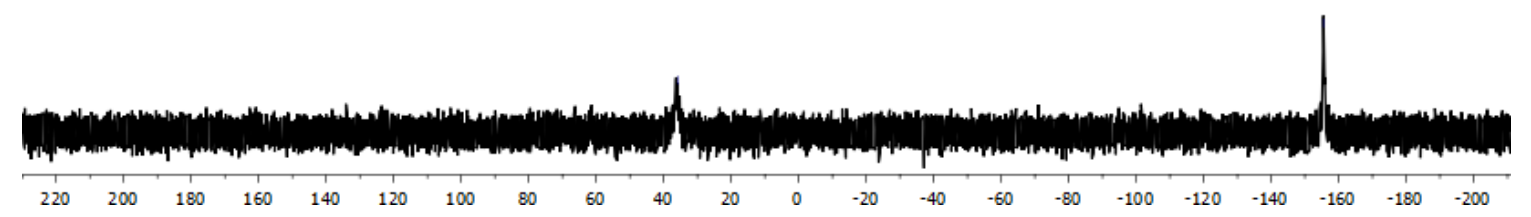




\section{Crystallographic Information}

Table S3. Crystal Data and Structure Refinement for $\mathbf{1 b}$ and $\mathbf{1 e .}$

Compound

Empirical formula

Formula weight

Temperature/K

Crystal system

Space group

$\mathrm{a} / \AA$

$\mathrm{b} / \AA$

$\mathrm{c} / \AA$

$\alpha /{ }^{\circ}$

$\beta /{ }^{\circ}$

$\gamma /{ }^{\circ}$

Volume/ $\AA^{3}$

$\mathrm{Z}$

$\rho_{\text {calc }} \mathrm{g} / \mathrm{cm}^{3}$

$\mu / \mathrm{mm}^{-1}$

$\mathrm{F}(000)$

Crystal size $/ \mathrm{mm}^{3}$

Radiation

$2 \Theta$ range for data

collection ${ }^{\circ}$

Index ranges

Reflections collected

Independent reflections

Data/restraints/parameters

Goodness-of-fit on $\mathrm{F}^{2}$

Final $\mathrm{R}$ indexes $[\mathrm{I}>=2 \sigma(\mathrm{I})]$

Final $\mathrm{R}$ indexes [all data]

Largest diff. peak/hole / e $\AA^{-3}$
$1 \mathbf{b}$

$\mathrm{C}_{35} \mathrm{H}_{35} \mathrm{P}_{5}$

610.48

$150.00(10)$

monoclinic

$\mathrm{P} 21 / \mathrm{c}$

$10.48163(17)$

$8.62157(13)$

$35.2744(5)$

90

92.1726(13)

90

$3185.39(8)$

4

1.273

2.834

1280.0

$0.131 \times 0.097 \times 0.087$

$\mathrm{Cu} \mathrm{K \alpha}(\lambda=1.54184)$

8.442 to 146.282

$-12 \leq \mathrm{h} \leq 12,-10 \leq \mathrm{k} \leq 10$, $-43 \leq 1 \leq 28$

27732

$6327\left[\mathrm{R}_{\text {int }}=0.0335, \mathrm{R}_{\text {sigma }}=\right.$ 0.0272]

$6327 / 0 / 366$

1.121

$\mathrm{R}_{1}=0.0514, \mathrm{wR}_{2}=0.1342$

$\mathrm{R}_{1}=0.0565, \mathrm{wR}_{2}=0.1377$

$0.77 /-0.42$ 1e

$\mathrm{C}_{30} \mathrm{H}_{20} \mathrm{~F}_{5} \mathrm{P}_{5}$

630.31

100.0

monoclinic

$\mathrm{P} 21 / \mathrm{c}$

12.2296(5)

$10.9727(5)$

20.6263(9)

90

91.1070(10)

90

2767.4(2)

4

1.513

0.385

1280.0

$0.261 \times 0.16 \times 0.04$

$\operatorname{MoK} \alpha(\lambda=0.71073)$

3.95 to 55.818

$-16 \leq \mathrm{h} \leq 16,-14 \leq \mathrm{k} \leq 14,-$ $27 \leq 1 \leq 27$

189482

$6609\left[R_{\text {int }}=0.0450, R_{\text {sigma }}=\right.$ $0.0155]$

$6609 / 0 / 361$

1.060

$\mathrm{R}_{1}=0.0305, \mathrm{wR}_{2}=0.0765$

$\mathrm{R}_{1}=0.0372, \mathrm{wR}_{2}=0.0796$

$0.94 /-0.34$ 
Table S4. Crystal Data and Structure Refinement for 1e' and $\mathbf{2 b}$.

Identification code

Empirical formula

Formula weight

Temperature/K

Crystal system

Space group

$\mathrm{a} / \AA$

$\mathrm{b} / \AA$

$\mathrm{c} / \AA$

$\alpha^{\circ}$

$\beta /{ }^{\circ}$

$\gamma /{ }^{\circ}$

Volume $/ \AA^{3}$

$\mathrm{Z}$

$\rho_{\text {calc }} \mathrm{g} / \mathrm{cm}^{3}$

$\mu / \mathrm{mm}^{-1}$

$\mathrm{F}(000)$

Crystal size $/ \mathrm{mm}^{3}$

Radiation

$2 \Theta$ range for data collection/ ${ }^{\circ}$

Index ranges

Reflections collected

Independent reflections

Data/restraints/parameters

Goodness-of-fit on $\mathrm{F}^{2}$

Final $\mathrm{R}$ indexes $[\mathrm{I}>=2 \sigma(\mathrm{I})]$

Final $\mathrm{R}$ indexes [all data]

Largest diff. peak/hole / e $\AA^{-3}$
$1 e^{\prime}$

$\mathrm{C}_{36} \mathrm{H}_{24} \mathrm{~F}_{6} \mathrm{P}_{6}$

756.37

$150.0(4)$

trigonal

$\mathrm{P}-3 \mathrm{c} 1$

22.8522(8)

$22.8522(8)$

$11.0927(3)$

90

90

120

$5016.8(4)$

6

1.502

0.382

2304.0

$0.311 \times 0.191 \times 0.152$

$\operatorname{MoK} \alpha(\lambda=0.71073)$

6.176 to 54.982

$-29 \leq \mathrm{h} \leq 29,-28 \leq \mathrm{k} \leq 29,-12$ $\leq 1 \leq 14$

43030

$3795\left[\mathrm{R}_{\text {int }}=0.0851, \mathrm{R}_{\text {sigma }}=\right.$ $0.0554]$

$3795 / 0 / 218$

1.083

$\mathrm{R}_{1}=0.0854, \mathrm{w}_{2}=0.2082$

$\mathrm{R}_{1}=0.1079, \mathrm{wR}_{2}=0.2230$

$2.15 /-0.77$

\section{2c}

$\mathrm{C}_{76} \mathrm{H}_{68} \mathrm{P}_{4} \mathrm{Si}_{4}$

1309.67

$150.00(10)$

triclinic

P -1

$14.3584(8)$

14.8803(8)

$17.9556(8)$

93.281(4)

97.417(4)

$110.542(5)$

$3540.6(3)$

2

1.228

1.972

1380

$0.09 \times 0.065 \times 0.042$

$\mathrm{Cu} \operatorname{Kla}(\lambda=1.54184)$

69.9790to 3.1850

$-17 \leq \mathrm{h} \leq 13,-16 \leq \mathrm{k} \leq$ $18,-20 \leq 1 \leq 21$

23980

$13172\left[\mathrm{R}_{\text {int }}=0.0468\right.$,

$\left.\mathrm{R}_{\text {sigma }}=0.0744\right]$

13172/0/757

1.017

$\mathrm{R}_{1}=0.0564, \mathrm{wR}_{2}=$

0.1311

$\mathrm{R}_{1}=0.0844, \mathrm{wR}_{2}=$

0.1480

$0.429 /-0.424$

Please see CIF file for detailed comments on crystal parameters. In particular we have detailed the basis for the ALERT B flags with the data for Compound 1e' under the_refine_special_details item in the CIF file. 
Table S5. Crystal Data and Structure Refinement for 5.

Identification code

Empirical formula

Formula weight

Temperature/K

Crystal system

Space group

$\mathrm{a} / \AA$

$\mathrm{b} / \AA$

$\mathrm{c} / \AA$

$\alpha /^{\circ}$

$\beta /{ }^{\circ}$

$\gamma /{ }^{\circ}$

Volume $/ \AA^{3}$

$\mathrm{Z}$

$\rho_{\text {calc }} \mathrm{g} / \mathrm{cm}^{3}$

$\mu / \mathrm{mm}^{-1}$

$\mathrm{F}(000)$

Crystal size $/ \mathrm{mm}^{3}$

Radiation

$2 \Theta$ range for data collection/ ${ }^{\circ}$

Index ranges

Reflections collected

Independent reflections

Data/restraints/parameters

Goodness-of-fit on $\mathrm{F}^{2}$

Final $\mathrm{R}$ indexes $[\mathrm{I}>=2 \sigma(\mathrm{I})]$

Final $\mathrm{R}$ indexes [all data]

Largest diff. peak/hole / e $\AA^{-3}$
5

$\mathrm{C}_{10} \mathrm{H}_{18} \mathrm{Cl}_{4} \mathrm{Fe}_{2} \mathrm{O}_{6}$

487.74

150.00(10)

triclinic

P-1

9.9831(6)

$10.0059(6)$

$10.5401(6)$

90.840(5)

91.631(5)

$111.782(5)$

976.92(10)

2

1.658

17.134

492.0

$0.267 \times 0.128 \times 0.101$

$\mathrm{CuK} \alpha(\lambda=1.54184)$

8.396 to 145.638

$-12 \leq \mathrm{h} \leq 12,-12 \leq \mathrm{k} \leq 12,-13 \leq 1 \leq 13$

4006

$4006\left[\mathrm{R}_{\text {int }}=0.0641, \mathrm{R}_{\text {sigma }}=0.0141\right]$

$4006 / 0 / 206$

1.123

$\mathrm{R}_{1}=0.0661, \mathrm{wR}_{2}=0.1900$

$\mathrm{R}_{1}=0.0690, \mathrm{wR}_{2}=0.1950$

$1.15 /-0.78$ 


\section{References}

1. Averre, C. E.; Coles, M. P.; Crossley, I. R.; Day, I. J., The open-chain triphosphanes RMe2SiCH2P(PR'2)2 (R = Me, Ph; R' = SiMe3, Cy, Ph). Dalton Trans. 2012, 41 (1), 278-84.

2. Greenacre, V. K.; Trathen, N.; Crossley, I. R., Ruthenaphosphaalkenyls: Synthesis, Structures, and Their Conversion to $\eta 2-P h o s p h a a l k e n e$ Complexes. Organometallics. 2015, 34 (11), 2533-2542.

3. Barrau, J.; Ben Hamida, N.; Agrebi, A.; Satge, J., Bis(dimethylgermyl)alkane-iron tetracarbonyls: synthesis, photolysis, and reactivity. 1989, 8 (7), 1585-1593.

4. Eisch, J. J.; Chiu, C. C. S., Rearrangements of (Chloromethyl)Organylsilanes Induced by LewisAcids Acids or by Lewis-Bases - Regioselective Methylenation of Allylic Systems. Heteroat. Chem. 1994, $5(3), 265-274$.

5. $\quad$ Cordaro, J. G.; Stein, D.; Ruegger, H.; Grutzmacher, H., Making the true "CP" ligand. Angew. Chem. Int. Ed. 2006, 45 (37), 6159-6162.

6. Samstag, W.; Engels, J. W., Stereoselektive Synthese phosphatmodifizierter DNA-Bausteine. Angew. Chem. 1992, 104 (10), 1367-1369.

7. Wucher, P.; Schwaderer, J. B.; Mecking, S., Solid-Supported Single-Component Pd(II) Catalysts for Polar Monomer Insertion Copolymerization. ACS. Catal. 2014, 4 (8), 2672-2679.

8. Siméon, F.; Jaffrès, P.-A.; Villemin, D., A direct and new convenient oxidation: Synthesis of substituted arylphosphonates from aromatics. Tetrahedron. 1998, 54 (34), 10111-10118.

9. Miles, J. A.; Beeny, M. T.; Ratts, K. W., General route to methoxy-substituted arylphosphonous dichlorides via mild Lewis acid catalysts. J. Org. Chem. 1975, 40 (3), 343-347.

10. Clark, T. J.; Rodezno, J. M.; Clendenning, S. B.; Aouba, S.; Brodersen, P. M.; Lough, A. J.; Ruda, H. E.; Manners, I., Rhodium-catalyzed dehydrocoupling of fluorinated phosphine-borane adducts: synthesis, characterization, and properties of cyclic and polymeric phosphinoboranes with electron-withdrawing substituents at phosphorus. Chem. Eur. J. 2005, 11 (15), 4526-4534.

11. Mahammad Ibrahim, A.; Mahadevan, V.; Srinivasan, M., Synthesis of phosphorus-containing alternating copolymers. Eur. Polym. J. 1988, 24 (4), 385-388.

12. Contrella, N. D.; Sampson, J. R.; Jordan, R. F., Copolymerization of Ethylene and Methyl Acrylate by Cationic Palladium Catalysts That Contain Phosphine-Diethyl Phosphonate Ancillary Ligands. Organometallics. 2014, 33 (13), 3546-3555.

13. Cherbuliez, E.; Weber, G.; Rabinowitz, J., Recherches sur la formation et la transformation des esters XL. Sur la phosphonylation d'alcools divers par l'oxyde p-fluorophénylphosphonique. Helv. Chim. Acta. 1962, 45 (7), 2665-2669.

14. Chua, C. J.; Ren, Y.; Baumgartner, T., Structure-Property Studies of Bichromophoric, PAHFunctionalized Dithieno[3,2-b:2 ',3 '-d]phospholes. Organometallics. 2012, 31 (6), 2425-2436.

15. Kilah, N. L.; Wild, S. B., Phosphine Complexes of an Enantiomerically Pure, Atropisomeric Arsenium Ion. Organometallics. 2012, 31 (7), 2658-2666.

16. Provis-Evans, C. B.; Emanuelsson, E. A. C.; Webster, R. L., Rapid Metal-Free Formation of Free Phosphines from Phosphine Oxides. Adv. Synth. Catal. 2018, 360 (20), 3999-4004.

17. Li, C.-J.; Lü, J.; Zhang, Z.-X.; Zhou, K.; Li, Y.; Qi, G.-H., Copper-catalyzed C-P cross-coupling of secondary phosphines with (hetero)aromatic bromide. Res. Chem. Intermed. 2018, 44 (7), 4547-4562.

18. Scherer, M.; Stein, D.; Breher, F.; Geier, J.; Schonberg, H.; Grutzmacher, H., Copper(I) chloride cluster complexes with pentaphenyl-cyclopentaphosphane as ligand. Z. Anorg. Allg. Chem. 2005, 631 (13-14), 2770-2774.

19. Wu, L.; Annibale, V. T.; Jiao, H.; Brookfield, A.; Collison, D.; Manners, I., Homo- and heterodehydrocoupling of phosphines mediated by alkali metal catalysts. Nat. Commun. 2019, 10 (1), 2786.

20. Smith, L. R.; Mills, J. L., An investigation of the ring size of cyclopolyphosphines. J. Am. Chem. Soc. 1976, 98 (13), 3852-3857.

21. Fluck, E.; Binder, H., Chemische Reaktionen der Perthiophosphonsäureanhydride. Z. Anorg. Allg. Chem. 1967, 354 (3-4), 113-129. 
22. Henderson, W. A.; Epstein, M.; Seichter, F. S., Some Aspects of the Chemistry of Cyclopolyphosphines. J. Am. Chem. Soc. 1963, 85 (16), 2462-2466.

23. King, A. K.; Buchard, A.; Mahon, M. F.; Webster, R. L., Facile, Catalytic Dehydrocoupling of Phosphines Using beta-Diketiminate Iron(II) Complexes. Chem. Eur. J. 2015, 21 (45), 15960-15963.

24. Arnáiz, F. J., A Convenient Way to Generate Hydrogen Chloride in the Freshman Lab. J. Chem. Educ. 1995, 72 (12), 1139. 